Supporting Information

\title{
Studies Targeting Ryanodol Result in an Annulation Reaction for the Synthesis of a Variety of Fused Carbocycles
}

\author{
Rajdip Karmakar, ${ }^{1}$ Arnold L. Rheingold, ${ }^{2}$ and Glenn C. Micalizio*, \\ ${ }^{1}$ Department of Chemistry, Dartmouth College, Burke Laboratory, Hanover, NH 03755 , \\ USA. ${ }^{2}$ University of California San Diego, La Jolla, CA 92093, USA. \\ Glenn.C.Micalizio@dartmouth.edu
}




\section{Table of Contents}

$\begin{array}{ll}\text { Section } & \text { Page }\end{array}$

$\begin{array}{ll}\text { I. Materials and Methods } & \text { S3 }\end{array}$

II. Experimental and Analytical Data

A. General Scheme for the Synthesis of Substrates $\quad$ S5

B. Detailed Procedure for the Synthesis of Substrates

C. Synthesis of Tricyclic Carbocycles by Ti-mediated Annulation Reaction $\quad$ S22

III. NMR Spectra of New Compounds

$\begin{array}{ll}\text { A. NMR Spectra of Substrates } & \text { S37 }\end{array}$

B. NMR Spectra of Products $\quad$ S45 


\section{Materials and Methods}

\section{A. Stereochemical Relationships}

All stereochemical relationships depicted are relative, not absolute (all chiral compounds are racemic mixtures).

\section{B. Experimental Setups}

All reactions were conducted in flame-dried glassware under an atmosphere of nitrogen and in anhydrous solvents unless otherwise indicated. All reagents and starting materials were purchased from commercial sources and used as received, unless otherwise indicated. Anhydrous dichloromethane $\left(\mathrm{CH}_{2} \mathrm{Cl}_{2}\right)$, diethyl ether $\left(\mathrm{Et}_{2} \mathrm{O}\right)$, tetrahydrofuran (THF), and toluene were obtained by passing commercially available HPLC grade solvents through a column of activated alumina using a Glass Contour Solvent Purification System by Pure Process Technology LLC. THF for the Ti-mediated annulation reaction was freshly distilled in $\mathrm{Na}$ /benzophenone still prior to its use. Titanium isopropoxide $\left.\left[\mathrm{Ti}(\mathrm{O} i \text {-Pr })_{4}\right)\right]$ was distilled prior to use and stored in a foilwrapped round bottom flask under an atmosphere of nitrogen. Said flask was stored in a desiccator when not in use. $n$-BuLi was purchased from Sigma-Aldrich as a $2.5 \mathrm{M}$ solution in hexanes, and was titrated against $N$-benzylbenzamide according to a literature procedure $^{1}$ to accurately determine the titer before use. Cyclopentylmagnesium chloride $\left(c-\mathrm{C}_{5} \mathrm{H}_{9} \mathrm{MgCl}\right)$ was purchased from Sigma-Aldrich as $2.0 \mathrm{M}$ solutions in $\mathrm{Et}_{2} \mathrm{O}$, and was titrated against salicylaldehyde phenylhydrazone according to a literature procedure ${ }^{2}$ to accurately determine the titer before use. Percent yields correspond to chromatographically and spectroscopically $\left({ }^{1} \mathrm{H}\right.$ NMR) homogeneous materials, unless otherwise stated. Flash chromatography was performed on a Biotage ${ }^{\circledR}$ Automated Liquid Chromatography System Isolera One ${ }^{\circledR}$ using Biotage ${ }^{\circledR}$ SNAP KP-Sil $10-25 \mathrm{~g}$ or Biotage ${ }^{\circledR}$ SNAP Ultra $25 \mu \mathrm{m}$ HP-Sphere 10-25g silica gel cartridges or performed using a forced flow of the indicated solvent system on Sorbent Technologies TM silica gel $60 \AA$ (40-63 $\mu \mathrm{m}$ particle size). Thin layer chromatography (TLC) analyses were performed on EMD TLC silica gel $60 \mathrm{~F}_{234}$ glass plates and the compounds were visualized by exposure to UV light $(254 \mathrm{~nm})$ followed by staining with $p$-anisaldehyde, cerium ammonium molybdate, or $\mathrm{KMnO}_{4}$.

\section{Instruments for the Characterization of the Synthesized Compounds}

${ }^{1} \mathrm{H}$ NMR spectra were recorded on a Bruker Avance III $500 \mathrm{MHz}$ (TBI probe) or a $600 \mathrm{MHz}\left(\mathrm{BBFO}\right.$ probe) spectrometer in chloroform- $d\left(\mathrm{CDCl}_{3}\right)$ or benzene- $d_{6}\left(\mathrm{C}_{6} \mathrm{D}_{6}\right)$ as 
indicated. All signals are reported in parts per million ( $\mathrm{ppm}$ ) and calibrated to the residual protium signal of chloroform $\left(\mathrm{CHCl}_{3}, 7.26 \mathrm{ppm}\right)$ or benzene $\left(\mathrm{C}_{6} \mathrm{H}_{6}, 7.15 \mathrm{ppm}\right)$. Signals are reported as $\delta$ chemical shifts in ppm (multiplicity, coupling constants in $\mathrm{Hz}$, integration). ${ }^{13} \mathrm{C}$ NMR spectra were recorded on a Bruker Avance III $600 \mathrm{MHz}$ (BBFO probe) spectrometer measured at $150 \mathrm{MHz}$ or a Bruker Avance III $500 \mathrm{MHz}$ (TBI probe) spectrometer measured at $125 \mathrm{MHz}$. All signals are reported in ppm and are calibrated to the central line of the residual solvent signal of $\mathrm{CHCl}_{3}(77.16 \mathrm{ppm})$. Signals are reported as $\delta$ chemical shift(s) in ppm with substitution on the carbon atom indicated as; (C), fully substituted; $(\mathrm{CH})$, methine; $\left(\mathrm{CH}_{2}\right)$, methylene; or $\left(\mathrm{CH}_{3}\right)$, methyl. Two-dimensional NMR spectra, including COSY, HSQC, and NOESY were recorded on a Bruker Avance III 600 $\mathrm{MHz}$ spectrometer (BBFO probe), or a Bruker Avance III $500 \mathrm{Mhz}$ spectrometer (TBI probe). Infrared spectra were recorded on a JASCO FT/IR-4100 Fourier Transform Infrared Spectrometer. IR absorption is reported as strong (s), medium (m), weak (w), or broad (br). High-resolution mass spectroscopy (HRMS) analyses were performed at the mass spectrometry laboratory of the University of Illinois at Urbana-Champaign. X-ray data were collected at UCSD Crystallography Facility using Bruker Single-Crystal Diffractometers.

\section{Characterization of the Synthesized Compounds}

All the newly synthesized compounds were characterized using analyzing both 1D $\left({ }^{1} \mathrm{H},{ }^{13} \mathrm{C}\right.$, DEPT-135) and selected 2D NMR (HSQC, HMBC, COSY, NOESY) spectra. The result of the analysis for each compound is depicted as a picture with selected homo- or heteroatom correlation to support the stereochemistry. Structure and stereochemistry of several compounds were further confirmed by X-ray crystallography. 


\section{Experimental and Analytical Data}

For the synthesis and characterization data of compounds $\mathbf{1 0}$ and 11, see ref. 6.

\section{A. General Scheme for the Synthesis of Substrates}

\section{1,5-Diketone Substrates}
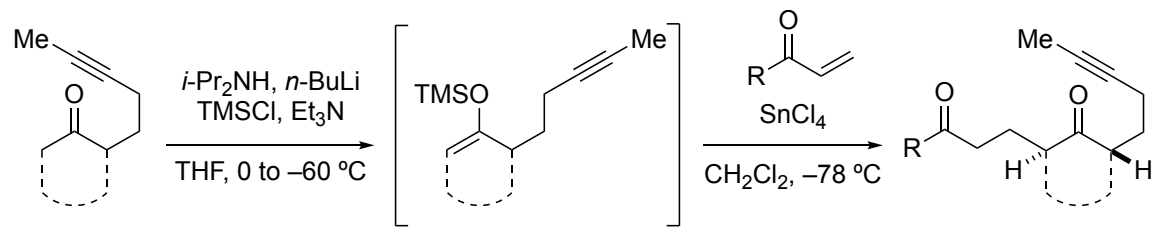

\section{1,4-Diketone Substrates}

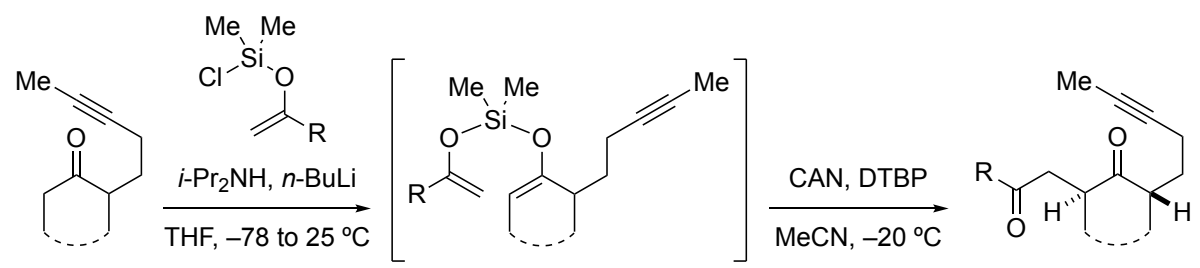

\section{1,3-Diketone Substrates}

Me<smiles>CC#CCCC1CCCCC1=O</smiles>

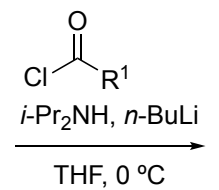<smiles>[R]C(=O)C1CCCC2CCC(C)CC21</smiles>

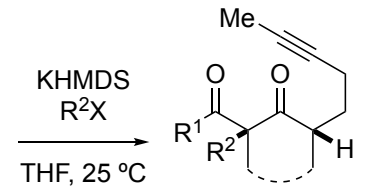

\section{B. Detailed Procedure for the Synthesis of Substrates}

\section{(1) Synthesis of Substrate 5}

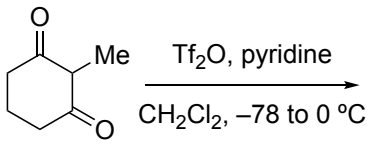

S1

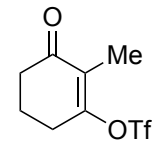

S2

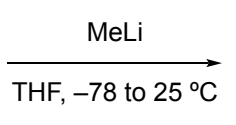

${ }^{\circ} \mathrm{C}$<smiles>CC#CCCCC(=O)O</smiles>

S3

\section{Preparation of S3:}

Using a modified procedure, ${ }^{3}$ to a stirred solution of 2-methylcyclohexane-1,3dione (S1, $5.0 \mathrm{~g}, 35.67 \mathrm{mmol}, 1.0$ equiv) and pyridine (5.8 $\mathrm{mL}, 71.34 \mathrm{mmol}, 2.0$ equiv) in dry $\mathrm{CH}_{2} \mathrm{Cl}_{2}(90 \mathrm{~mL})$ at $-78{ }^{\circ} \mathrm{C}$ was slowly added $\mathrm{Tf}_{2} \mathrm{O}(7.2 \mathrm{~mL}, 42.81 \mathrm{mmol}, 1.2$ equiv), and the reaction mixture was warmed to $0{ }^{\circ} \mathrm{C}$. After complete consumption of S1 (TLC 
monitoring), $1 \mathrm{~N}$ aq. $\mathrm{HCl}$ was added to the reaction mixture. The layers were separated and the aqueous phase was extracted with $\mathrm{CH}_{2} \mathrm{Cl}_{2}$ (x 2). The combined organic phase was concentrated and filtered through a pad of silica gel with 33\% EtOAc in hexanes. The filtrate was concentrated to get $8.7 \mathrm{~g} \mathrm{S2}$ (94\% yield) as light brown oil, which was used in the following step without further purification.

Using a modified procedure, ${ }^{3}$ to a stirred solution of $\mathbf{S 2}(\sim 8.7 \mathrm{~g}, 33.69 \mathrm{mmol}, 1.1$ equiv) in dry THF $(120 \mathrm{~mL})$ at $-78^{\circ} \mathrm{C}$ was added MeLi solution $(20 \mathrm{~mL}, 32.0 \mathrm{mmol}, 1.6$ $\mathrm{M}$ in $\mathrm{Et}_{2} \mathrm{O}, 1.0$ equiv) dropwise. After $15 \mathrm{~min}$, the cooling bath was removed to let the reaction mixture warm to room temperature. The reaction was quenched with sat. aq. $\mathrm{NH}_{4} \mathrm{Cl}$. The layers were separated and the aqueous phase was extracted with $\mathrm{Et}_{2} \mathrm{O}$ (x 2). The combined organic phase was washed with brine, dried over anhydrous $\mathrm{MgSO}_{4}$, filtered, and the filtrate was concentrated under reduced pressure. The crude was purified on a silica gel column to obtain $1.85 \mathrm{~g} \mathrm{S3}$ (46\% yield) as colorless oil.

\section{Analytical data for compound S3:}

${ }^{1} \mathbf{H}$ NMR $\left(600 \mathrm{MHz}, \mathrm{CDCl}_{3}\right): \delta 2.55(\mathrm{t}, J=7.2 \mathrm{~Hz}, 2 \mathrm{H}), 2.17-2.14(\mathrm{~m}, 5 \mathrm{H}), 1.77(\mathrm{t}, J=$ $2.7 \mathrm{~Hz}, 3 \mathrm{H}), 1.76-1.71(\mathrm{~m}, 2 \mathrm{H})$.

${ }^{13}$ C NMR (150 MHz, $\left.\mathrm{CDCl}_{3}\right): \delta 208.54,78.22,76.34,42.41,30.01,29.93,18.11,3.44$.

HRMS (ESI-TOF) (m/z): [M + H $]^{+}$calcd for $\mathrm{C}_{8} \mathrm{H}_{13} \mathrm{O}$ 125.0966; found, 125.0962 .

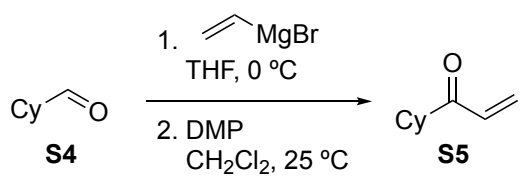

\section{Preparation of S5:}

Using a modified procedure, ${ }^{4}$ to a stirred solution of cyclohexanecarboxaldehyde (S4, $5.0 \mathrm{~g}, 45.5 \mathrm{mmol}, 1.0$ equiv) in dry THF $(200 \mathrm{~mL})$ at $0{ }^{\circ} \mathrm{C}$ was added vinyl magnesium bromide (55 mL, $55 \mathrm{mmol}, 1 \mathrm{M}$ in THF, 1.2 equiv) dropwise. After $15 \mathrm{~min}$, complete consumption of $\mathbf{S} 4$ was observed (by TLC) and the reaction was quenched with sat. aq. $\mathrm{NH}_{4} \mathrm{Cl}$ solution at $0{ }^{\circ} \mathrm{C}$ and warmed to room temperature. The layers were separated and the aqueous phase was extracted with ethyl acetate (x 2). The combined organic phase was washed with brine, dried over anhydrous $\mathrm{MgSO}_{4}$, filtered, and the filtrate was concentrated under reduced pressure. The crude oil (light yellow) was dissolved in dry $\mathrm{CH}_{2} \mathrm{Cl}_{2}$ and DMP (21 g, $50.5 \mathrm{mmol}, 1.1$ equiv) was added at $0{ }^{\circ} \mathrm{C}$. The reaction mixture was stirred for $1 \mathrm{~h}$ at ambient temperature, and then filtered through a plug of silica gel. The filtrate was washed successively with water, sat. aq. $\mathrm{NaHCO}_{3}$, and 
brine, dried over anhydrous $\mathrm{MgSO}_{4}$, filtered and concentrated under reduced pressure. The crude was purified on a silica gel column, which furnished $4.96 \mathrm{~g} \mathrm{S5}$ (84\% yield over 2 steps) as light yellow oil.

${ }^{1}$ H NMR $\left(600 \mathrm{MHz}, \mathrm{CDCl}_{3}\right): \delta 6.42(\mathrm{dd}, J=17.5,10.6 \mathrm{~Hz}, 1 \mathrm{H}), 6.25(\mathrm{dd}, J=17.5,1.3$ $\mathrm{Hz}, 1 \mathrm{H}), 5.74$ (dd, $J=10.6,1.4 \mathrm{~Hz}, 1 \mathrm{H}), 2.64-2.59(\mathrm{~m}, 1 \mathrm{H}), 1.84-1.78(\mathrm{~m}, 4 \mathrm{H}), 1.70$ $1.67(\mathrm{~m}, 1 \mathrm{H}), 1.40-1.22(\mathrm{~m}, 5 \mathrm{H})$.

${ }^{13}$ C NMR (150 MHz, $\left.\mathrm{CDCl}_{3}\right): \delta 203.52(\mathrm{C}), 134.96(\mathrm{CH}), 127.73(\mathrm{CH}), 48.19(\mathrm{CH})$, $28.54\left(\mathrm{CH}_{2}\right), 25.87\left(\mathrm{CH}_{2}\right), 25.69\left(\mathrm{CH}_{2}\right)$.

HRMS (ESI-TOF) (m/z): [M + H $]^{+}$calcd for $\mathrm{C}_{9} \mathrm{H}_{14} \mathrm{O}$ 138.1045; found, 138.1043 .

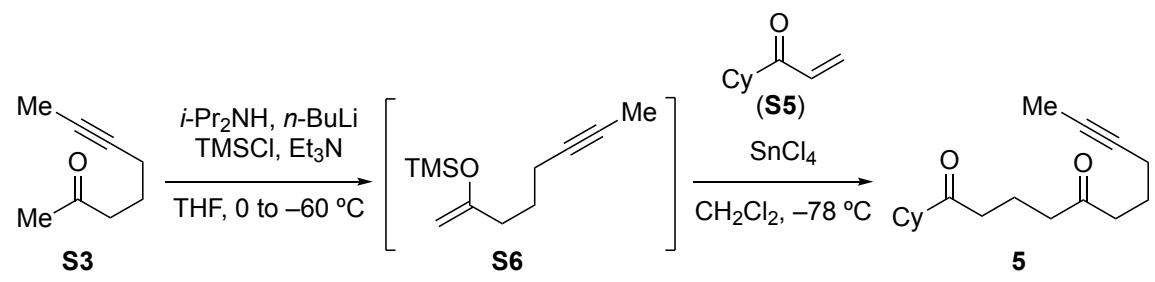

\section{Preparation of 5:}

Using a modified procedure, ${ }^{5}$ to a stirred solution of diisopropylamine $(6.2 \mathrm{~mL}$, $44.29 \mathrm{mmol}, 5.5$ equiv) in dry THF $(100 \mathrm{~mL})$ at $0{ }^{\circ} \mathrm{C}$ was added $n$-BuLi $(16.9 \mathrm{~mL}, 40.26$ mmol, $2.39 \mathrm{M}$ in hexanes, 5.0 equiv). After $15 \mathrm{~min}$, the prepared LDA solution was cooled to $-78{ }^{\circ} \mathrm{C}$. To the cold LDA solution was added TMSCl $(10.2 \mathrm{~mL}, 80.53 \mathrm{mmol}$, 10 equiv) followed by a solution of $\mathbf{S 3}(1.0 \mathrm{~g}, 8.05 \mathrm{mmol}, 1.0$ equiv) in $25 \mathrm{~mL}$ dry THF (additional $5 \mathrm{~mL}$ wash), and the mixture was stirred for 30 minutes at the same temperature. Triethylamine $(15 \mathrm{~mL})$ was added followed by a sat. aq. $\mathrm{NaHCO}_{3}$ solution and the reaction mixture was allowed to warm up to room temperature. The layers were separated and the aqueous phase was extracted with pentane (x 2). The combined organic phase was dried over anhydrous $\mathrm{K}_{2} \mathrm{CO}_{3}$, filtered, and the filtrate was concentrated under reduced pressure to afford the silyl enol ether (S6) as colorless oil, which was used immediately without further purification. Cyclohexyl vinyl ketone (S5, $421 \mathrm{mg}, 3.04$ mmol, 1.0 equiv) was added to the crude $\mathbf{S 6}$. The mixture was dissolved in anhydrous benzene and dried under reduced pressure (x 3). The mixture was dissolved in $100 \mathrm{~mL}$ anhydrous $\mathrm{CH}_{2} \mathrm{Cl}_{2}$ and the solution was cooled to $-78{ }^{\circ} \mathrm{C}$. $\mathrm{SnCl}_{4}(16.1 \mathrm{~mL}, 16.10 \mathrm{mmol}$, $1.0 \mathrm{M}$ in $\mathrm{CH}_{2} \mathrm{Cl}_{2}, 2.0$ equiv) was added slowly and the stirring was continued for $3 \mathrm{~h}$. The reaction was quenched with sat. aq. $\mathrm{Na}_{2} \mathrm{CO}_{3}$ solution at $-78{ }^{\circ} \mathrm{C}$, and the mixture was warmed up to room temperature. The layers were separated and the aqueous phase was extracted with $\mathrm{CH}_{2} \mathrm{Cl}_{2}$ (x 2). The combined organic phase was washed with brine, dried over anhydrous $\mathrm{MgSO}_{4}$, filtered, and the filtrate was concentrated under reduced 
pressure. The crude was purified by silica gel column chromatography to afford $442 \mathrm{mg} 5$ ( $21 \%$ yield over 2 steps) as colorless oil.

\section{Analytical data for compound 5:}

TLC: $\mathrm{R}_{\mathrm{f}}=0.50$ (20\% EtOAc in hexanes).

${ }^{1} \mathbf{H}$ NMR $\left(600 \mathrm{MHz}, \mathrm{CDCl}_{3}\right): \delta 2.48(\mathrm{t}, J=7.3 \mathrm{~Hz}, 2 \mathrm{H}), 2.44(\mathrm{t}, J=7.0 \mathrm{~Hz}, 2 \mathrm{H}), 2.41(\mathrm{t}$, $J=7.1 \mathrm{~Hz}, 2 \mathrm{H}), 2.31-2.26(\mathrm{~m}, 1 \mathrm{H}), 2.14-2.10(\mathrm{~m}, 2 \mathrm{H}), 1.82-1.77(\mathrm{~m}, 4 \mathrm{H}), 1.76-1.73$ $(\mathrm{m}, 5 \mathrm{H}), 1.70$ (quin, $J=7.1 \mathrm{~Hz}, 2 \mathrm{H}), 1.65-1.62(\mathrm{~m}, 1 \mathrm{H}), 1.32-1.20(\mathrm{~m}, 4 \mathrm{H}), 1.19-$ $1.12(\mathrm{~m}, 1 \mathrm{H})$.

${ }^{13} \mathrm{C}$ NMR (150 MHz, $\left.\mathrm{CDCl}_{3}\right): \delta 213.62(\mathrm{C}), 210.22(\mathrm{C}), 78.18(\mathrm{C}), 76.32(\mathrm{C}), 50.77$ $(\mathrm{CH}), 41.78\left(\mathrm{CH}_{2}\right), 41.36\left(\mathrm{CH}_{2}\right), 39.35\left(\mathrm{CH}_{2}\right), 28.45\left(\mathrm{CH}_{2}\right), 25.82\left(\mathrm{CH}_{2}\right), 25.64\left(\mathrm{CH}_{2}\right)$, $25.63\left(\mathrm{CH}_{2}\right), 22.86\left(\mathrm{CH}_{2}\right), 18.12\left(\mathrm{CH}_{2}\right), 17.73\left(\mathrm{CH}_{2}\right), 3.43\left(\mathrm{CH}_{3}\right)$.

IR (neat, $\left.\mathrm{cm}^{-1}\right)$ : 3403 (w, br), 2924 (s), 2852 (s), 1705 (s), 1448 (m), 1406 (m), 1372 (m), $1144(\mathrm{~m}), 1092(\mathrm{w}), 998(\mathrm{w})$.

HRMS (ESI-TOF) (m/z): [M + H] calcd for $\mathrm{C}_{17} \mathrm{H}_{27} \mathrm{O}_{2}$ 263.2011; found, 263.2007.

\section{(2) Synthesis of Substrate 7}

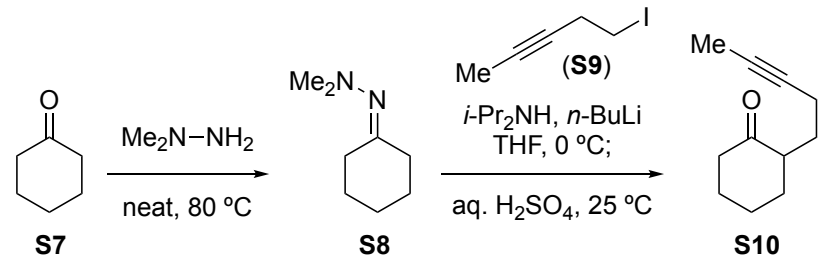

\section{Preparation of S10:}

Using a modified procedure, ${ }^{6} N, N$-dimethylhydrazine $(13.5 \mathrm{~g}, 224.2 \mathrm{mmol}, 1.1$ equiv) was slowly added to a flask containing cyclohexanone $(20.0 \mathrm{~g}, 203.8 \mathrm{mmol}, 1.0$ equiv) at room temperature. The mixture was stirred at $80{ }^{\circ} \mathrm{C}$ overnight. The reaction mixture was allowed to cool down to room temperature and the formed water was carefully removed using a pipette. The reaction mixture was dried over anhydrous $\mathrm{MgSO}_{4}$, filtered (washed with small amount of ethyl acetate) and concentrated under reduced pressure to get crude hydrazone $\mathbf{S 8}$ (25.2 g, 88\% yield) as light yellow oil. The crude was used in the next step without further purification. The analytical data matched with previous report. ${ }^{3}$

Using a modified procedure, ${ }^{6}$ to a solution of diisopropylamine $(4.8 \mathrm{~mL}, 34.23$ mmol, 1.2 equiv) in dry THF $(40 \mathrm{~mL})$ at $0{ }^{\circ} \mathrm{C}$ was added $n$-BuLi $(15 \mathrm{~mL}, 32.8 \mathrm{mmol}$, 
$2.19 \mathrm{M}$ in hexanes, 1.15 equiv). After stirring for $15 \mathrm{~min}$, a solution of crude hydrazone S8 (4 g, $28.52 \mathrm{mmol}, 1.0$ equiv) in $25 \mathrm{~mL}$ dry THF (additional $5 \mathrm{~mL}$ wash) was added to the prepared LDA. After stirring for $30 \mathrm{~min}$ at $0{ }^{\circ} \mathrm{C}, 5$-iodo-2-pentyne $(\mathbf{S 9}, 6.64 \mathrm{~g}, 34.23$ mmol, 1.2 equiv) was added dropwise. The reaction mixture was stirred for $1 \mathrm{~h}$ before pouring into an Erlenmeyer flask containing $1 \mathrm{M}$ aq. $\mathrm{H}_{2} \mathrm{SO}_{4}(100 \mathrm{~mL})$ and diethyl ether $(100 \mathrm{~mL})$ and the biphasic mixture was stirred overnight at room temperature. The organic phase was separated, washed successively with water, aq. sat. $\mathrm{NaHCO}_{3}$ solution, and brine, dried over anhydrous $\mathrm{MgSO}_{4}$, filtered and concentrated under reduced pressure. The crude material was purified on a silica gel column (0 to $10 \%$ EtOAc in hexane) to afford $\mathbf{S 1 0}$ (3.95 g, 84\% yield) as colorless oil.

\section{Analytical data for compound S8:}

${ }^{1}$ H NMR $\left(500 \mathrm{MHz}, \mathrm{CDCl}_{3}\right): \delta 2.46-2.44(\mathrm{~m}, 2 \mathrm{H}), 2.37(\mathrm{~s}, 6 \mathrm{H}), 2.19-2.17(\mathrm{~m}, 2 \mathrm{H})$, $1.66-1.62(\mathrm{~m}, 2 \mathrm{H}), 1.61-1.54(\mathrm{~m}, 4 \mathrm{H})$.

${ }^{13} \mathbf{C}$ NMR $\left(125 \mathrm{MHz}, \mathrm{CDCl}_{3}\right): \delta 170.1(\mathrm{C}), 47.5\left(\mathrm{CH}_{3}\right), 35.9\left(\mathrm{CH}_{2}\right), 28.6\left(\mathrm{CH}_{2}\right), 27.4$ $\left(\mathrm{CH}_{2}\right), 26.6\left(\mathrm{CH}_{2}\right), 26.0\left(\mathrm{CH}_{2}\right)$.

\section{Analytical data for compound S10:}

TLC: $\mathrm{R}_{\mathrm{f}}=0.37$ (10\% EtOAc in hexanes).

${ }^{1} \mathbf{H}$ NMR $\left(600 \mathrm{MHz}, \mathrm{CDCl}_{3}\right): \delta 2.47-2.41(\mathrm{~m}, 1 \mathrm{H}), 2.38-2.28(\mathrm{~m}, 2 \mathrm{H}), 2.18-2.08(\mathrm{~m}$, $3 \mathrm{H}), 2.08-2.02(\mathrm{~m}, 1 \mathrm{H}), 1.99-1.93(\mathrm{~m}, 1 \mathrm{H}), 1.86-1.82(\mathrm{~m}, 1 \mathrm{H}), 1.75-1.73(\mathrm{~m}, 3 \mathrm{H}), 1.71-$ $1.60(\mathrm{~m}, 2 \mathrm{H}), 1.36-1.27$ (m, 2H).

${ }^{13}$ C NMR $\left(150 \mathrm{MHz}, \mathrm{CDCl}_{3}\right): \delta 212.91(\mathrm{C}), 78.66(\mathrm{C}), 75.80(\mathrm{C}), 49.24\left(\mathrm{CH}_{3}\right), 42.18$ $\left(\mathrm{CH}_{2}\right), 33.87\left(\mathrm{CH}_{2}\right), 28.71\left(\mathrm{CH}_{2}\right), 28.07\left(\mathrm{CH}_{2}\right), 25.07\left(\mathrm{CH}_{2}\right), 16.40\left(\mathrm{CH}_{2}\right), 3.47\left(\mathrm{CH}_{3}\right)$.

IR (neat, $\mathrm{cm}^{-1}$ ): 2932 (s), 2960 (s), 1709 (s), 1448 (s), 1371 (m), 1338 (m), 1312 (m), 1227 (m), 1129 (s), $1072(\mathrm{~m}), 1042(\mathrm{w}), 836(\mathrm{w})$.

HRMS (ESI-TOF) (m/z): [M+ H] ${ }^{+}$calcd for $\mathrm{C}_{11} \mathrm{H}_{17} \mathrm{O}$ 165.1279; found, 165.1278. 

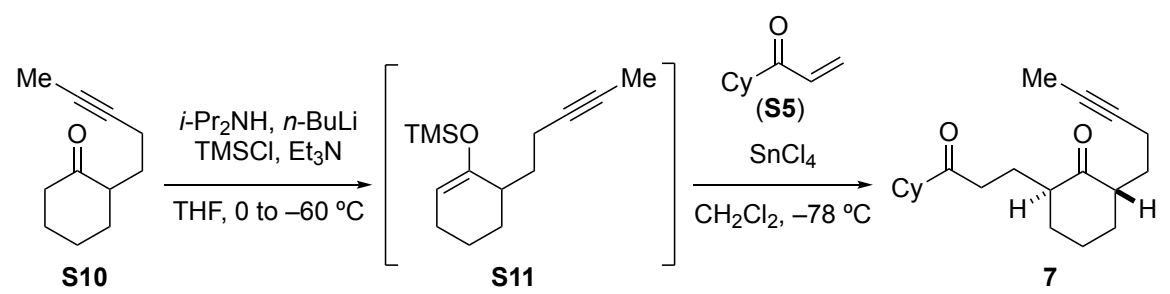

\section{Preparation of 7:}

Using a modified procedure, ${ }^{5}$ to a stirred solution of diisopropylamine $(2.4 \mathrm{~mL}$, $16.74 \mathrm{mmol}, 5.5$ equiv) in dry THF $(40 \mathrm{~mL})$ at $0{ }^{\circ} \mathrm{C}$ was added $n$-BuLi $(6.5 \mathrm{~mL}, 15.22$ mmol, $2.34 \mathrm{M}$ in hexanes, 5.0 equiv). After $15 \mathrm{~min}$, the prepared LDA solution was cooled to $-60{ }^{\circ} \mathrm{C}$. To the cold LDA solution was added TMSCl $(3.8 \mathrm{~mL}, 30.22 \mathrm{mmol}, 10$ equiv) followed by a solution of $\mathbf{S 1 0}$ (500 mg, $3.04 \mathrm{mmol}, 1.0$ equiv) in $12 \mathrm{~mL}$ dry THF (additional $3 \mathrm{~mL}$ wash), and the mixture was stirred for 15 minutes at the same temperature. Triethylamine $(6 \mathrm{~mL})$ was added followed by a sat. aq. $\mathrm{NaHCO}_{3}$ solution and the reaction mixture was allowed to warm up to room temperature. The layers were separated and the aqueous phase was extracted with pentane (x 2). The combined organic phase was dried over anhydrous $\mathrm{K}_{2} \mathrm{CO}_{3}$, filtered, and the filtrate was concentrated under reduced pressure to afford the silyl enol ether (S11) as colorless oil, which was used immediately without further purification. Cyclohexyl vinyl ketone (S5, $421 \mathrm{mg}, 3.04$ mmol, 1.0 equiv) was added to the crude $\mathbf{S 1 1}$. The mixture was dissolved in anhydrous benzene and dried under reduced pressure (x 3). The mixture was dissolved in $40 \mathrm{~mL}$ anhydrous $\mathrm{CH}_{2} \mathrm{Cl}_{2}$ and the solution was cooled to $-78{ }^{\circ} \mathrm{C}$. $\mathrm{SnCl}_{4}(6.1 \mathrm{~mL}, 6.1 \mathrm{mmol}, 1.0$ $\mathrm{M}$ in $\mathrm{CH}_{2} \mathrm{Cl}_{2}, 2.0$ equiv) was added slowly down the side of the flask and continue stirring for $3 \mathrm{~h}$. The reaction was quenched with sat. aq. $\mathrm{Na}_{2} \mathrm{CO}_{3}$ solution at $-78{ }^{\circ} \mathrm{C}$, and the mixture was warmed up to room temperature. The layers were separated and the aqueous phase was extracted with $\mathrm{CH}_{2} \mathrm{Cl}_{2}$ (x 2). The combined organic phase was washed with brine, dried over anhydrous $\mathrm{MgSO}_{4}$, filtered, and the filtrate was concentrated under reduced pressure. The crude was purified by silica gel column chromatography to afford $273 \mathrm{mg} 7$ (30\% yield over 2 steps) as colorless oil.

\section{Analytical data for compound 7:}

TLC: $\mathrm{R}_{\mathrm{f}}=0.25(10 \%$ EtOAc in hexanes $)$.

${ }^{1} \mathbf{H}$ NMR $\left(600 \mathrm{MHz}, \mathrm{CDCl}_{3}\right): \delta 2.56-2.51(\mathrm{~m}, 1 \mathrm{H}), 2.42-2.31(\mathrm{~m}, 3 \mathrm{H}), 2.27-2.22(\mathrm{~m}$, $1 \mathrm{H}), 2.14-2.01(\mathrm{~m}, 2 \mathrm{H}), 1.95-1.82(\mathrm{~m}, 4 \mathrm{H}), 1.77-1.64(\mathrm{~m}, 9 \mathrm{H}), 1.62-1.57(\mathrm{~m}, 3 \mathrm{H}), 1.52-$ $1.46(\mathrm{~m}, 1 \mathrm{H}), 1.42-1.36(\mathrm{~m}, 1 \mathrm{H}), 1.29-1.09(\mathrm{~m}, 5 \mathrm{H})$

${ }^{13}$ C NMR (150 MHz, $\left.\mathrm{CDCl}_{3}\right): \delta 215.65$ (C), 213.47 (C), 78.27 (C), 76.04 (C), 50.82 $(\mathrm{CH}), 48.61(\mathrm{CH}), 47.22(\mathrm{CH}), 38.07\left(\mathrm{CH}_{2}\right), 33.37\left(\mathrm{CH}_{2}\right), 33.08\left(\mathrm{CH}_{2}\right), 29.41\left(\mathrm{CH}_{2}\right)$, 
$28.48\left(\mathrm{CH}_{2}\right), 28.41\left(\mathrm{CH}_{2}\right), 25.81\left(\mathrm{CH}_{2}\right), 25.63\left(\mathrm{CH}_{2}\right), 25.60\left(\mathrm{CH}_{2}\right), 24.53\left(\mathrm{CH}_{2}\right), 20.67$ $\left(\mathrm{CH}_{2}\right), 16.58\left(\mathrm{CH}_{2}\right), 3.42\left(\mathrm{CH}_{3}\right)$.

IR (neat, $\mathrm{cm}^{-1}$ ): 2929 (s), 2855 (s), 1704 (s), 1448 (s), 1410 (w), 1374 (m), 1239 (w), $1146(\mathrm{~m} 0,994(\mathrm{~m})$.

HRMS (ESI-TOF) (m/z): [M + H] calcd for $\mathrm{C}_{20} \mathrm{H}_{31} \mathrm{O}_{2}$ 303.2324; found, 303.2322.

Structure Determination: The structure of 7 was determined by ${ }^{1} \mathrm{H}$ and ${ }^{13} \mathrm{C}$ NMR. The connectivity of the atoms were determined using HSQC and HMBC data. The relative stereochemistry was not identified at this point. However, the structure was assigned by analogy to the structure of the tricyclic products $\mathbf{8}$ and $\mathbf{9}$ (isolated after carrying out the Ti-mediated annulation reaction of 7) whose structures were confirmed by X-ray analysis. $^{7}$

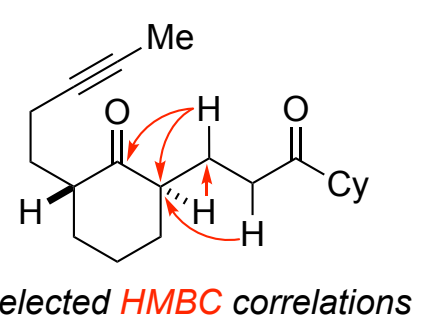

\section{(3) Synthesis of Substrate 12}

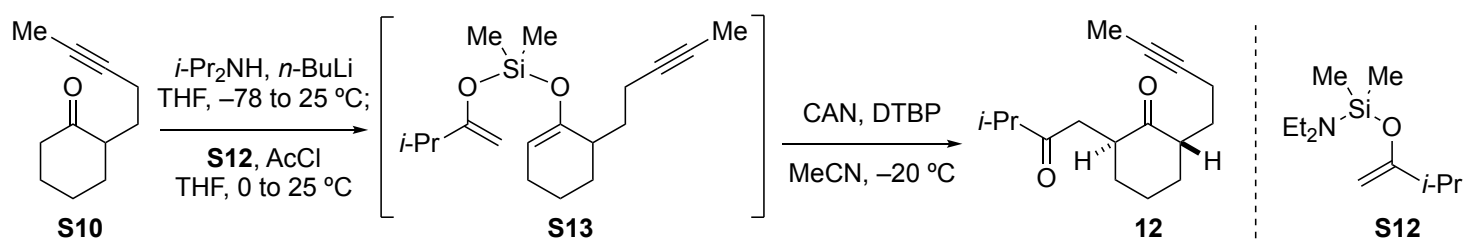

Using a modified procedure, ${ }^{8}$ to a stirred solution of diisopropylamine $(1.6 \mathrm{~mL}$, $11.2 \mathrm{mmol}, 1.15$ equiv) in dry THF $(30 \mathrm{~mL})$ at $0{ }^{\circ} \mathrm{C}$ was added $n$-BuLi $(7.44 \mathrm{~mL}, 10.71$ mmol, $1.44 \mathrm{M}$ in hexanes, 1.1 equiv). After $15 \mathrm{~min}$, the prepared LDA solution was cooled down to $-78{ }^{\circ} \mathrm{C}$ and a solution of $\mathbf{S 1 0}(1.6 \mathrm{~g}, 9.74 \mathrm{mmol}, 1.0$ equiv) in $16 \mathrm{~mL}$ dry THF (additional $2 \mathrm{~mL}$ wash $\mathrm{x}$ 2) was added dropwise, and continue stirring for $1 \mathrm{~h}$ at the same temperature. In a timely manner, $\mathbf{S 1 2}^{8}(2.4 \mathrm{~g}, 11.2 \mathrm{mmol}, 1.15$ equiv) was dissolved in dry THF $(25 \mathrm{~mL})$ at $0{ }^{\circ} \mathrm{C}$ in a separate flask and $\mathrm{AcCl}(0.78 \mathrm{~mL}, 10.91 \mathrm{mmol}, 1.12$ equiv) was added dropwise. The ice-bath was removed after $5 \mathrm{~min}$ and stirring was continued at ambient temperature for $15 \mathrm{~min}$. This solution was transferred to the precooled $\left(-78{ }^{\circ} \mathrm{C}\right)$ solution of Li-enolate prepared earlier. After $30 \mathrm{~min}$, the cooling bath was removed and stirring was continued for $1.5 \mathrm{~h}$. The reaction was quenched with aq. 
sat. $\mathrm{NH}_{4} \mathrm{Cl}$ solution, and extracted with pentane (x 2). The combined organic phase was dried over anhydrous $\mathrm{MgSO}_{4}$, filtered and concentrated under reduced pressure to afford crude $\mathbf{S 1 3}$ as colorless oil, which was used in the following step without any purification and characterization.

Using a modified procedure, ${ }^{9}$ 2,6-Di-tert-butylpyridine $(9.62 \mathrm{~mL}, 42.86 \mathrm{mmol}$, 4.4 equiv) was slowly added to a flask containing CAN (11.75 g, $21.43 \mathrm{mmol}, 2.2$ equiv) in anhydrous $\mathrm{MeCN}(125 \mathrm{~mL})$ at $-25^{\circ} \mathrm{C}$. After $5 \mathrm{~min}$, a solution of crude $\mathbf{S 1 3}$ in $100 \mathrm{~mL}$ anhydrous $\mathrm{MeCN}$ (additional $20 \mathrm{~mL}$ wash) was added to the flask. The mixture was stirred for $30 \mathrm{~h}$ at $-20{ }^{\circ} \mathrm{C}$. The reaction mixture was poured into a separatory funnel containing sat. aq. $\mathrm{NaHCO}_{3}$ solution and extracted with $\mathrm{CH}_{2} \mathrm{Cl}_{2}$ (x 3). The combined organic phase was washed with brine, dried over anhydrous $\mathrm{MgSO}_{4}$, filtered and concentrated under reduced pressure. The crude was purified on a silica gel column to obtain $540 \mathrm{mg}$ of $\mathbf{1 2}$ (22\% yield over 2 steps) as colorless oil.

\section{Analytical data for compound 12:}

TLC: $\mathrm{R}_{\mathrm{f}}=0.26(10 \%$ EtOAc in hexanes $)$.

${ }^{1} \mathbf{H}$ NMR $\left(600 \mathrm{MHz}, \mathrm{CDCl}_{3}\right): \delta 3.14-3.09(\mathrm{~m}, 1 \mathrm{H}), 2.93(\mathrm{dd}, J=17.7,7.5 \mathrm{~Hz}, 1 \mathrm{H}), 2.67-$ $2.61(\mathrm{~m}, 1 \mathrm{H}), 2.55-2.51(\mathrm{~m}, 1 \mathrm{H}), 2.21(\mathrm{dd}, J=17.4,5.4 \mathrm{~Hz}, 1 \mathrm{H}), 2.14-2.08(\mathrm{~m}, 2 \mathrm{H})$, 2.03-1.97 (m, 2H), 1.89-1.84 (m, 2H), 1.83-1.79 (m, 1H), 1.78-1.73 (m, 4H), 1.72-1.63 (m, 2H), 1.41-1.35 (m, 1H), 1.12-1.09 (m, 6H).

${ }^{13}$ C NMR (150 MHz, $\mathrm{CDCl}_{3}$ ): $\delta 214.38$ (C), 212.95 (C), 78.14 (C), 76.08 (C), 49.48 $(\mathrm{CH}), 42.71(\mathrm{CH}), 41.12(\mathrm{CH}), 40.13\left(\mathrm{CH}_{2}\right), 33.67\left(\mathrm{CH}_{2}\right), 31.75\left(\mathrm{CH}_{2}\right), 30.68\left(\mathrm{CH}_{2}\right)$, $20.57\left(\mathrm{CH}_{2}\right), 18.28\left(\mathrm{CH}_{3}\right), 18.17\left(\mathrm{CH}_{3}\right), 16.75\left(\mathrm{CH}_{2}\right), 3.48\left(\mathrm{CH}_{3}\right)$.

IR (neat, $\left.\mathrm{cm}^{-1}\right)$ : 2965 (s), 2933 (s), 2864 (m), 1704 (s), 1672 (w), 1449 (m), 1383 (w), $1355(w), 1104(w), 1038(\mathrm{~s})$.

HRMS (ESI-TOF) (m/z): [M + H] calcd for $\mathrm{C}_{16} \mathrm{H}_{25} \mathrm{O}_{2}$ 249.1855; found, 249.1860.

Structure Determination: The structure of $\mathbf{1 2}$ was determined by ${ }^{1} \mathrm{H}$ and ${ }^{13} \mathrm{C}$ NMR. The connectivity of atoms was supported by HSQC, HMBC, and COSY data. The relative stereochemistry was assigned by analogy to the structure of the tricyclic product $\mathbf{1 4}$ (isolated after carrying out the Ti-mediated annulation reaction of 12) whose structures were confirmed by X-ray analysis. ${ }^{7}$ 


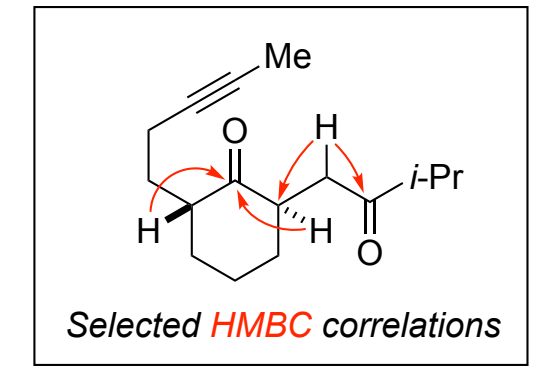

\section{(4) Synthesis of Substrate 15}

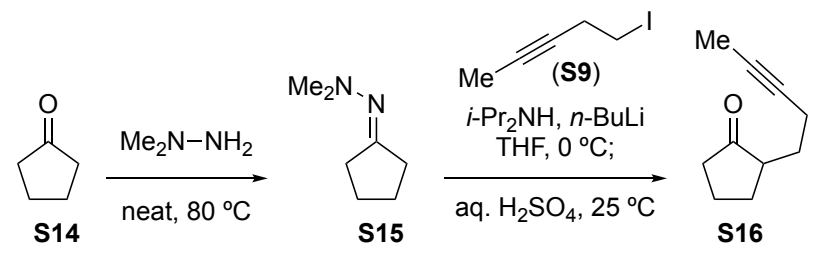

\section{Preparation of S16:}

Using a modified procedure, ${ }^{6} N, N$-dimethylhydrazine $(15.7 \mathrm{~g}, 261.5 \mathrm{mmol}, 1.1$ equiv) was slowly added to a flask containing cyclopentanone $(20.0 \mathrm{~g}, 237.8 \mathrm{mmol}, 1.0$ equiv) at room temperature. The mixture was stirred at $80{ }^{\circ} \mathrm{C}$ overnight. The reaction mixture was allowed to cool down to room temperature and the formed water was carefully removed using a pipette. The reaction mixture was dried over anhydrous $\mathrm{MgSO}_{4}$, filtered (washed with small amount of ethyl acetate) and concentrated under reduced pressure to get crude hydrazone $\mathbf{S 1 5}$ (26 g, 87\% yield) as light yellow oil. The crude was used in the next step without further purification.

Using a modified procedure, ${ }^{6}$ to a solution of diisopropylamine $(4.0 \mathrm{~mL}, 28.52$ mmol, 1.2 equiv) in dry THF $(60 \mathrm{~mL})$ at $0{ }^{\circ} \mathrm{C}$ was added $n$-BuLi $(12.5 \mathrm{~mL}, 27.34 \mathrm{mmol}$, $2.19 \mathrm{M}$ in hexanes, 1.15 equiv). After stirring for $15 \mathrm{~min}$, a solution of crude hydrazone S15 (3.0 g, $23.77 \mathrm{mmol}, 1.0$ equiv) in $20 \mathrm{~mL}$ dry THF (additional $5 \mathrm{~mL}$ wash) was added to the prepared LDA. After stirring for $30 \mathrm{~min}$ at $0{ }^{\circ} \mathrm{C}, 5$-iodo-2-pentyne $(5.6 \mathrm{~g}, 28.52$ mmol, 1.25 equiv) was added dropwise. The reaction mixture was stirred for $1 \mathrm{~h}$ before pouring into an Erlenmeyer flask containing $1 \mathrm{M}$ aq. $\mathrm{H}_{2} \mathrm{SO}_{4}(80 \mathrm{~mL})$ and diethyl ether $(80 \mathrm{~mL})$ and the biphasic mixture was stirred overnight at room temperature. The organic phase was separated, washed successively with water, aq. sat. $\mathrm{NaHCO}_{3}$ solution, and brine, dried over anhydrous $\mathrm{MgSO}_{4}$, filtered and concentrated under reduced pressure. The crude material was purified on a silica gel column ( 0 to $10 \%$ EtOAc in hexane) to afford $\mathbf{S 1 6}$ (2.85 g, 80\% yield) as colorless oil. 


\section{Analytical data for compound S15:}

TLC: $\mathrm{R}_{\mathrm{f}}=0.17$ (33\% EtOAc in hexanes).

${ }^{1} \mathbf{H}$ NMR $\left(500 \mathrm{MHz}, \mathrm{CDCl}_{3}\right): \delta 2.46(\mathrm{~s}, 6 \mathrm{H}), 2.37(\mathrm{t}, J=7.2 \mathrm{~Hz}, 2 \mathrm{H}), 2.33(\mathrm{t}, J=7.2$, 2H), 1.78-1.70 (m, 4H).

${ }^{13}$ C NMR (125 MHz, $\left.\mathrm{CDCl}_{3}\right): \delta 175.89(\mathrm{C}), 47.05\left(\mathrm{CH}_{3}\right), 33.54\left(\mathrm{CH}_{2}\right), 29.34\left(\mathrm{CH}_{2}\right)$, $24.92\left(\mathrm{CH}_{2}\right), 24.18\left(\mathrm{CH}_{2}\right)$.

IR (neat, cm $\mathrm{cm}^{-1}$ ): 2956 (s), 2855 (s), 2816 (s), $2771(\mathrm{~m}), 1741$ (m), 1658 (s), 1467 (s), 1451 (s), 1428 (s), 1181 (m), 1153 (m), 1021 (m), 972 (s).

HRMS (ESI-TOF) (m/z): [M + H $]^{+}$calcd for $\mathrm{C}_{7} \mathrm{H}_{15} \mathrm{~N}_{2}$ 127.1235; found, 127.1239.

\section{Analytical data for compound S16:}

TLC: $\mathrm{R}_{\mathrm{f}}=0.34(10 \%$ EtOAc in hexanes $)$.

${ }^{1}$ H NMR $\left(600 \mathrm{MHz}, \mathrm{CDCl}_{3}\right): \delta 2.32-2.07(\mathrm{~m}, 6 \mathrm{H}), 2.03-1.91(\mathrm{~m}, 2 \mathrm{H}), 1.82-1.74(\mathrm{~m}$, $4 \mathrm{H}), 1.52-1.46(\mathrm{~m}, 1 \mathrm{H}), 1.43-1.37(\mathrm{~m}, 1 \mathrm{H})$.

${ }^{13}$ C NMR (150 MHz, $\mathrm{CDCl}_{3}$ ): $\delta 221.01$ (C), 78.23 (C), 76.21 (C), $48.14(\mathrm{CH}), 38.09$ $\left(\mathrm{CH}_{2}\right), 29.42\left(\mathrm{CH}_{2}\right), 29.06\left(\mathrm{CH}_{2}\right), 20.70\left(\mathrm{CH}_{2}\right), 16.97\left(\mathrm{CH}_{2}\right), 3.45\left(\mathrm{CH}_{3}\right)$.

IR (neat, cm ${ }^{-1}$ ): 2957 (s), 2919 (s), 2863 (s), 1737 (s), 1449 (m), 1408 (m), 1352 (m), $1327(\mathrm{w}), 1271(\mathrm{w}), 1159(\mathrm{~s}), 1120(\mathrm{w}), 1006(\mathrm{w}), 929(\mathrm{w}), 820(\mathrm{~m})$.

HRMS (ESI-TOF) (m/z): $[\mathrm{M}+\mathrm{H}]^{+}$calcd for $\mathrm{C}_{10} \mathrm{H}_{15} \mathrm{O}$ 151.1123; found, 151.1124 .

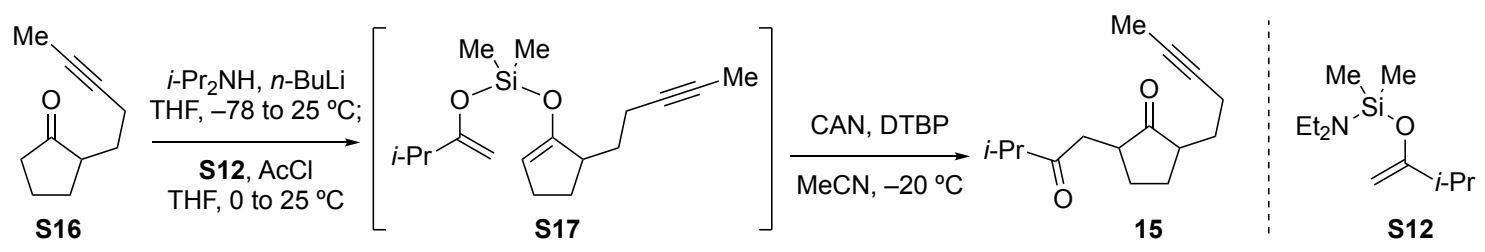

\section{Preparation of 15:}

Following a modified procedure, ${ }^{8}$ to a stirred solution of diisopropylamine $(0.44$ $\mathrm{mL}, 3.06 \mathrm{mmol}, 1.15$ equiv) in dry THF $(4 \mathrm{~mL})$ at $0{ }^{\circ} \mathrm{C}$ was added $n$-BuLi $(1.28 \mathrm{~mL}, 2.93$ mmol, $2.29 \mathrm{M}$ in hexanes, 1.1 equiv). After $15 \mathrm{~min}$, the prepared LDA solution was cooled down to $-78{ }^{\circ} \mathrm{C}$ and a solution of $\mathbf{S 1 6}$ (400 mg, $2.66 \mathrm{mmol}, 1.0$ equiv) in $6 \mathrm{~mL}$ dry THF (additional $2 \mathrm{~mL}$ wash $\mathrm{x}$ 2) was added dropwise, and continue stirring for $1 \mathrm{~h}$. In a timely manner, $\mathbf{S 1 2}^{8}$ (688 mg, $3.2 \mathrm{mmol}, 1.2$ equiv) was dissolved in dry THF (12 mL) at 
$0{ }^{\circ} \mathrm{C}$ in a separate flask and $\mathrm{AcCl}(218 \mu \mathrm{L}, 3.06 \mathrm{mmol}, 1.15$ equiv $)$ was added dropwise. The ice-bath was removed after $5 \mathrm{~min}$ and stirring was continued at ambient temperature for $15 \mathrm{~min}$. This solution was transferred to the precooled $\left(-78{ }^{\circ} \mathrm{C}\right)$ solution of Li-enolate prepared earlier. After $30 \mathrm{~min}$, the cooling bath was removed and stirring was continued for $1.5 \mathrm{~h}$. The reaction was quenched with aq. sat. $\mathrm{NH}_{4} \mathrm{Cl}$ solution, and extracted with pentane (x 2). The combined organic phase was dried over anhydrous $\mathrm{MgSO}_{4}$, filtered and concentrated under reduced pressure to afford crude $\mathbf{S 1 7}$ as colorless oil, which was used in the following step without any purification and characterization.

Following a modified procedure, ${ }^{9}$ 2,6-Di-tert-butylpyridine $(2.64 \mathrm{~mL}, 11.72$ mmol, 4.4 equiv) was slowly added to a flask containing CAN ( $3.22 \mathrm{~g}, 5.87 \mathrm{mmol}, 2.2$ equiv) in anhydrous $\mathrm{MeCN}(50 \mathrm{~mL})$ at $-25^{\circ} \mathrm{C}$. After $5 \mathrm{~min}$, a solution of crude $\mathbf{S 1 7}$ in 40 $\mathrm{mL}$ anhydrous $\mathrm{MeCN}$ (additional $10 \mathrm{~mL}$ wash) was added to the flask. The mixture was stirred for $30 \mathrm{~h}$ at $-20{ }^{\circ} \mathrm{C}$. The reaction mixture was poured into a separatory funnel containing sat. aq. $\mathrm{NaHCO}_{3}$ solution and extracted with $\mathrm{CH}_{2} \mathrm{Cl}_{2}$ (x 3). The combined organic phase was washed with brine, dried over anhydrous $\mathrm{MgSO}_{4}$, filtered and concentrated under reduced pressure. The crude was purified on a silica gel column, which furnished $275 \mathrm{mg}$ of $\mathbf{1 5}$ (colorless oil, $44 \%$ yield over 2 steps) as an inseparable mixture of diastereomers.

\section{Analytical data for compound 15:}

TLC: $\mathrm{R}_{\mathrm{f}}=0.47$ (20\% EtOAc in hexanes).

${ }^{1} \mathbf{H}$ NMR (600 MHz, $\mathrm{CDCl}_{3}$ ): $\delta 2.92$ (dd, $J=18.1,3.7 \mathrm{~Hz}, 1 \mathrm{H}$, first diastereomer), 2.86 (dd, $J=17.9,3.7 \mathrm{~Hz}, 1 \mathrm{H}$, second diastereomer), 2.65-2.51 (m, mixed), 2.45-2.39 (m, mixed), 2.36-2.31 (m, 1H, first diastereomer), 2.30-2.22 (m, mixed), 2.21-2.14 (m, mixed), 2.12-2.06 (m, 1H, second diastereomer), 2.01-1.96 ( $\mathrm{m}, 1 \mathrm{H}$, first diastereomer), 1.91-1.86 (m, 1H, second diastereomer), 1.76-1.74 (m, 3H, mixed), 1.72-1.66 (m, $1 \mathrm{H}$, second diastereomer), 1.54-1.41 ( $\mathrm{m}$, mixed), 1.09-1.07 (m, 6H, mixed).

${ }^{13} \mathbf{C}$ NMR $\left(150 \mathrm{MHz}, \mathrm{CDCl}_{3}\right)$ : All discernible peaks for both diastereomers. $\delta 221.26(\mathrm{C})$, 221.11 (C), 212.62 (C), 212.44 (C), 78.24 (C), 78.23 (C), 76.23 (C), 76.23 (C), 47.81 $(\mathrm{CH}), 46.39(\mathrm{CH}), 45.10(\mathrm{CH}), 43.87(\mathrm{CH}), 40.84(\mathrm{CH}), 40.82\left(\mathrm{CH}_{2}\right), 40.69\left(\mathrm{CH}_{2}\right), 40.29$ $\left(\mathrm{CH}_{2}\right), 29.75\left(\mathrm{CH}_{2}\right), 29.64\left(\mathrm{CH}_{2}\right), 27.66\left(\mathrm{CH}_{2}\right), 27.56\left(\mathrm{CH}_{2}\right), 26.88\left(\mathrm{CH}_{2}\right), 26.33\left(\mathrm{CH}_{2}\right)$, $18.22\left(\mathrm{CH}_{3}\right), 18.19\left(\mathrm{CH}_{3}\right), 18.18\left(\mathrm{CH}_{3}\right), 18.17\left(\mathrm{CH}_{3}\right), 17.04\left(\mathrm{CH}_{2}\right), 16.88\left(\mathrm{CH}_{2}\right), 3.48$ $\left(\mathrm{CH}_{3}\right)$.

IR (neat, $\mathrm{cm}^{-1}$ ): 2969 (s), 2924 (s), 2874 (m), 1738 (s), 1711 (s), 1467 (m), 1452 (m), $1387(w), 1035(w)$.

HRMS (ESI-TOF) (m/z): [M + H] calcd for $\mathrm{C}_{15} \mathrm{H}_{23} \mathrm{O}_{2}$ 235.1698; found, 235.1702. 
(5) Synthesis of Substrate 17

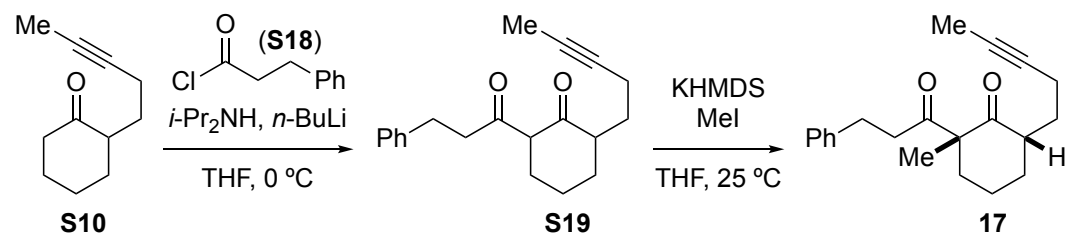

Using a modified procedure, ${ }^{6}$ to a stirring solution of diisopropylamine $(3.3 \mathrm{~mL}$, $23.44 \mathrm{mmol}, 1.1$ equiv) in dry THF $(24 \mathrm{~mL})$ at $-78{ }^{\circ} \mathrm{C}$, was added $n$-BuLi $(10.7 \mathrm{~mL}$, $23.44 \mathrm{mmol}, 2.19 \mathrm{M}$ in hexanes, 1.1 equiv). After, stirring for $45 \mathrm{~min}$, a solution of $\mathbf{S 1 0}$ ( $3.5 \mathrm{~g}, 21.31 \mathrm{mmol}, 1.0$ equiv) in dry THF ( $22 \mathrm{~mL}$, additional $2 \mathrm{~mL}$ wash) was added dropwise. After $1 \mathrm{~h}$, the generated enolate was transferred to a precooled solution of acid chloride S18 (3.8 mL, $25.57 \mathrm{mmol}, 1.2$ equiv) in $24 \mathrm{~mL}$ dry THF, and the stirring was continued for $2 \mathrm{~h}$. The reaction was quenched with an aqueous saturated $\mathrm{NaHCO}_{3}$ solution at $-78{ }^{\circ} \mathrm{C}$ and the solution was allowed to warm up to room temperature. The layers were separated. The aqueous phase was extracted with ethyl acetate (x 2). The combined organic phase was washed with brine, dried over anhydrous $\mathrm{MgSO}_{4}$, filtered, and concentrated under reduced pressure. The crude was purified on a silica gel column to afford $3.98 \mathrm{~g} \mathrm{S19} \mathrm{(light} \mathrm{yellow} \mathrm{oil,} \mathrm{63 \%} \mathrm{yield)} \mathrm{as} \mathrm{a} \mathrm{mixture} \mathrm{of} \mathrm{diastereomers} \mathrm{and} \mathrm{enol}$ isomer, along with $560 \mathrm{mg}$ of starting ketone S10 (colorless oil, 16\%).

Using a modified procedure, ${ }^{6}$ KHMDS $(28.1 \mathrm{~mL}, 14.1 \mathrm{mmol}, 0.5 \mathrm{M}$ in PhMe, 1.05 equiv) was added dropwise to a solution of $\mathbf{S 1 9}$ (3.97 g, $13.4 \mathrm{mmol}, 1.0$ equiv) in dry THF $(60 \mathrm{~mL})$ at room temperature. After $30 \mathrm{~min}$, iodomethane $(1.1 \mathrm{~mL}, 17.4 \mathrm{mmol}$, 1.3 equiv) was added dropwise and stirring was continued for $5 \mathrm{~h}$. The reaction was quenched by addition of $20 \mathrm{~mL}$ aqueous saturated $\mathrm{NaHCO}_{3}$ solution. The aqueous phase was extracted with EtOAc (x 2). The combined organic phase was washed with brine, dried over anhydrous $\mathrm{MgSO}_{4}$, filtered, and concentrated under reduced pressure. The crude material was purified on a silica gel column ( 0 to $10 \%$ EtOAc in hexanes) to obtain $17(1.52 \mathrm{~g}, 37 \%)$ as colorless oil.

\section{Analytical data for compound 17:}

TLC: $\mathrm{R}_{\mathrm{f}}=0.37$ (10\% EtOAc in hexanes).

${ }^{1} \mathbf{H}$ NMR (600 MHz, $\left.\mathrm{CDCl}_{3}\right): \delta 7.30-7.28(\mathrm{~m}, 2 \mathrm{H}), 7.22-7.18(\mathrm{~m}, 3 \mathrm{H}), 2.95(\mathrm{t}, J=8.1$ $\mathrm{Hz}, 2 \mathrm{H}), 2.80-2.71(\mathrm{~m}, 3 \mathrm{H}), 2.26-2.10(\mathrm{~m}, 4 \mathrm{H}), 1.95$ (sext, $J=6.9 \mathrm{~Hz}, 1 \mathrm{H}), 1.89-1.80$ $(\mathrm{m}, 2 \mathrm{H}), 1.78(\mathrm{t}, J=2.7 \mathrm{~Hz}, 3 \mathrm{H}), 1.69-1.65(\mathrm{~m}, 1 \mathrm{H}), 1.43-1.36(\mathrm{~m}, 1 \mathrm{H}), 1.41(\mathrm{~s}, 3 \mathrm{H})$, 1.33 (sext, $J=6.6 \mathrm{~Hz}, 1 \mathrm{H}$ ).

${ }^{13}$ C NMR (150 MHz, $\left.\mathrm{CDCl}_{3}\right)$ : $\delta 213.68(\mathrm{C}), 209.54(\mathrm{C}), 141.51(\mathrm{C}), 128.45(\mathrm{CH}), 128.42$ $(\mathrm{CH}), 126.00(\mathrm{CH}), 78.25(\mathrm{C}), 76.21(\mathrm{C}), 62.23(\mathrm{C}), 45.50(\mathrm{CH}), 41.71\left(\mathrm{CH}_{2}\right), 34.99$ 
$\left(\mathrm{CH}_{2}\right), 33.04\left(\mathrm{CH}_{2}\right), 30.36\left(\mathrm{CH}_{2}\right), 28.42\left(\mathrm{CH}_{2}\right), 20.58\left(\mathrm{CH}_{2}\right), 19.85\left(\mathrm{CH}_{3}\right), 16.35\left(\mathrm{CH}_{2}\right)$, $3.48\left(\mathrm{CH}_{3}\right)$.

IR (neat, $\left.\mathrm{cm}^{-1}\right)$ : $3088(\mathrm{w}), 3061(\mathrm{~m}), 3030(\mathrm{~m}), 2936$ (s), 2864 (s), 1713 (s), $1696(\mathrm{~s})$, 1603 (w), 1495 (m), 1453 (s), 1370 (m), 1266 (s), 1155 (w), 1077 (m), 989 (m), 739 (s), 698 (s).

HRMS (ESI-TOF) (m/z): [M + H] calcd for $\mathrm{C}_{21} \mathrm{H}_{27} \mathrm{O}_{2}$ 311.2011; found, 311.2014.

Structure Determination: The structure of 17 was determined by ${ }^{1} \mathrm{H}$ and ${ }^{13} \mathrm{C} N M R$. The relative stereochemistry was assigned based on HSQC, HMBC, COSY, and NOESY analysis. $^{7}$

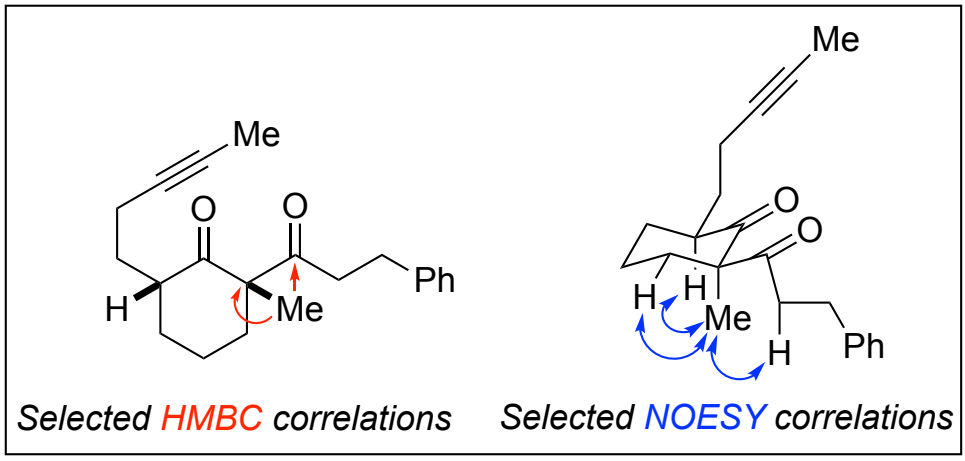

(6) Synthesis of Substrate 20
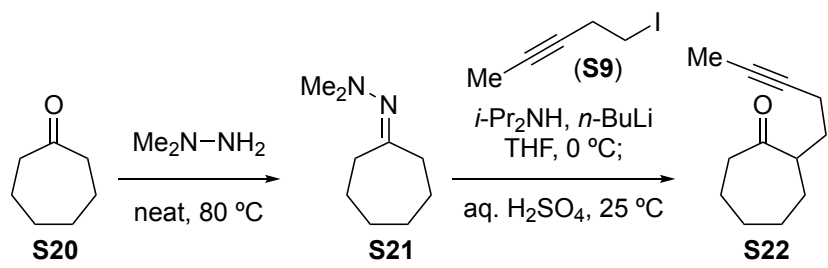

\section{Preparation of S19:}

Using a modified procedure, ${ }^{6} \mathrm{~N}, \mathrm{~N}$-dimethylhydrazine $(11.79 \mathrm{~g}, 196.1 \mathrm{mmol}, 1.1$ equiv) was slowly added to a flask containing cycloheptanone $(20.0 \mathrm{~g}, 178.3 \mathrm{mmol}, 1.0$ equiv) at room temperature. The mixture was stirred at $80^{\circ} \mathrm{C}$. After overnight stirring, the formed water was carefully removed using a pipette. The reaction mixture was dried over anhydrous $\mathrm{MgSO}_{4}$, filtered (washed with small amount of ethyl acetate) and concentrated under reduced pressure to get crude hydrazone $\mathbf{S 2 1}$ (26.64 g, 97\% yield) as light yellow oil. The crude was used in the next step without further purification. 
Using a modified procedure, ${ }^{6}$ to a solution of diisopropylamine $(2.7 \mathrm{~mL}, 19.45$ mmol, 1.2 equiv) in dry THF $(24 \mathrm{~mL})$ at $0{ }^{\circ} \mathrm{C}$ was added $n$-BuLi $(9.4 \mathrm{~mL}, 18.64 \mathrm{mmol}$, $1.98 \mathrm{M}$ in hexanes, 1.15 equiv). After stirring for 15 minutes, a solution of crude hydrazone S21 (2.5 g, $16.21 \mathrm{mmol}, 1.0$ equiv) in $10 \mathrm{~mL}$ dry THF (additional $1 \mathrm{~mL}$ wash) was added to the prepared LDA. After stirring for 30 minutes at $0{ }^{\circ} \mathrm{C}, 5$-iodo-2-pentyne ( $3.8 \mathrm{~g}, 19.45 \mathrm{mmol}, 1.2$ equiv) was added dropwise. The reaction mixture was stirred for $1 \mathrm{~h}$ before pouring into an Erlenmeyer flask containing $1 \mathrm{M}$ aq. $\mathrm{H}_{2} \mathrm{SO}_{4}(70 \mathrm{~mL})$ and diethyl ether $(70 \mathrm{~mL})$ and the biphasic mixture was stirred overnight at room temperature. The organic layer was separated, washed successively with water, aq. sat. $\mathrm{NaHCO}_{3}$ solution, and brine, dried over anhydrous $\mathrm{MgSO}_{4}$, filtered and concentrated under reduced pressure. The crude material was purified on a silica gel column (0 to $10 \%$ EtOAc in hexane) to afford $\mathbf{S 2 2}$ (2.18 g, 75\% yield) as colorless oil.

\section{Analytical Data for Compound S21:}

TLC: $\mathbf{R}_{\mathrm{f}}=0.27$ (33\% EtOAc in hexanes).

${ }^{1} \mathbf{H}$ NMR $\left(600 \mathrm{MHz}, \mathrm{CDCl}_{3}\right): \delta 2.62-2.59(\mathrm{~m}, 2 \mathrm{H}), 2.40-2.38(\mathrm{~m}, 8 \mathrm{H}), 1.63-1.60(\mathrm{~m}$, $4 \mathrm{H}), 1.58-1.51(\mathrm{~m}, 4 \mathrm{H})$.

${ }^{13} \mathrm{C}$ NMR (150 MHz, $\left.\mathrm{CDCl}_{3}\right): \delta 174.35(\mathrm{C}), 47.26\left(\mathrm{CH}_{3}\right), 37.23\left(\mathrm{CH}_{2}\right), 31.07\left(\mathrm{CH}_{2}\right)$, $30.62\left(\mathrm{CH}_{2}\right), 30.13\left(\mathrm{CH}_{2}\right), 27.41\left(\mathrm{CH}_{2}\right), 25.24\left(\mathrm{CH}_{2}\right)$.

IR (Thin Film $\mathrm{CH}_{2} \mathrm{Cl}_{2}, \mathrm{~cm}^{-1}$ ): 2978 (m), 2922 (s), 2850 (s), 2811 (m), 2770 (m), 1741 (m), $1616(\mathrm{~m}), 1449$ (m).

HRMS (ESI-TOF) (m/z): [M+H] $]^{+}$calcd for $\mathrm{C}_{9} \mathrm{H}_{19} \mathrm{~N}_{2}$ 155.1548; found, 155.1544 .

\section{Analytical Data for Compound S22:}

TLC: $\mathbf{R}_{\mathrm{f}}=0.46$ (10\% EtOAc in hexanes).

${ }^{1} \mathbf{H}$ NMR $\left(600 \mathrm{MHz}, \mathrm{CDCl}_{3}\right): \delta 2.70-2.65(\mathrm{~m}, 1 \mathrm{H}), 2.47-2.45(\mathrm{~m}, 2 \mathrm{H}), 2.13-2.09(\mathrm{~m}$, $2 \mathrm{H}), 1.91-1.78(\mathrm{~m}, 5 \mathrm{H}), 1.76-1.74(\mathrm{~m}, 3 \mathrm{H}), 1.67-1.59(\mathrm{~m}, 1 \mathrm{H}), 1.48-1.38(\mathrm{~m}, 2 \mathrm{H}), 1.33-$ $1.26(\mathrm{~m}, 2 \mathrm{H})$.

${ }^{13} \mathrm{C}$ NMR (150 MHz, $\left.\mathrm{CDCl}_{3}\right): \delta 215.94(\mathrm{C}), 78.70(\mathrm{C}), 76.29(\mathrm{C}), 50.87(\mathrm{CH}), 43.23$ $\left(\mathrm{CH}_{2}\right), 31.41\left(\mathrm{CH}_{2}\right), 31.38\left(\mathrm{CH}_{2}\right), 29.54\left(\mathrm{CH}_{2}\right), 28.85\left(\mathrm{CH}_{2}\right), 24.50\left(\mathrm{CH}_{2}\right), 16.77\left(\mathrm{CH}_{2}\right)$, $3.69\left(\mathrm{CH}_{3}\right)$.

IR (Thin Film $\mathrm{CH}_{2} \mathrm{Cl}_{2}, \mathrm{~cm}^{-1}$ ): 2926 (s), 2953 (s), 1699 (s), 1453 (m).

HRMS (EI) (m/z): [M] $]^{+}$calcd for $\mathrm{C}_{12} \mathrm{H}_{18} \mathrm{O}$ 178.1358; found, 178.1355 . 


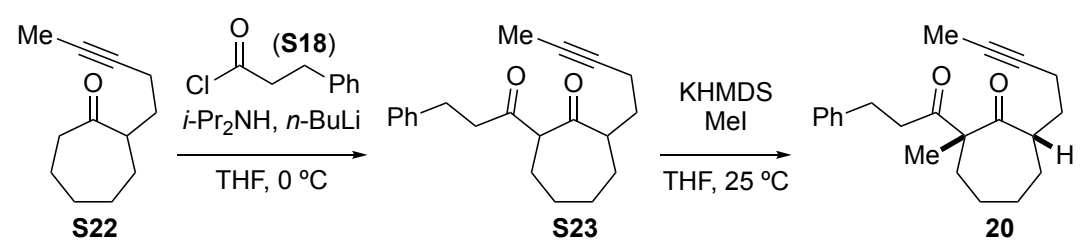

\section{Preparation of 20:}

Using a modified procedure, ${ }^{6}$ to a stirring solution of diisopropylamine $(0.49 \mathrm{~mL}$, $3.5 \mathrm{mmol}, 1.25$ equiv) in dry $\mathrm{THF}(4 \mathrm{~mL})$ at $-78{ }^{\circ} \mathrm{C}$, was added $n$-BuLi $(1.5 \mathrm{~mL}, 3.37$ mmol, 2.25 $\mathrm{M}$ in hexanes, 1.2 equiv). After, stirring for $45 \mathrm{~min}$, a solution of $\mathbf{S 2 2}$ (500 $\mathrm{mg}, 2.80 \mathrm{mmol}, 1.0$ equiv) in dry THF (8 mL, additional $2 \mathrm{~mL}$ wash) was added dropwise. After $1 \mathrm{~h}$, the generated enolate was transferred to a precooled solution of acid chloride $\mathbf{S 1 8}$ (0.5 mL, $3.36 \mathrm{mmol}, 1.2$ equiv) in $10 \mathrm{~mL}$ dry THF, and the stirring was continued for $2 \mathrm{~h}$. The reaction was quenched with an aqueous saturated $\mathrm{NaHCO}_{3}$ solution at $-78{ }^{\circ} \mathrm{C}$ and the solution was allowed to warm up to room temperature. The layers were separated. The aqueous phase was extracted with ethyl acetate (x 2). The combined organic phase was washed with brine, dried over anhydrous $\mathrm{MgSO}_{4}$, filtered, and concentrated under reduced pressure. The dried crude $\mathbf{S 2 3}$ (light yellow oil) was dissolved in dry THF (24 mL), and KMHDS (5.6 mL, $2.8 \mathrm{mmol}, 0.5 \mathrm{M}$ in PhMe, 1.0 equiv) was added dropwise at room temperature. After $30 \mathrm{~min}$, iodomethane $(0.23 \mathrm{~mL}$, 3.69 mmol, 1.3 equiv) was added dropwise and stirring was continued for $5 \mathrm{~h}$. The reaction was quenched by addition of $10 \mathrm{~mL}$ aqueous saturated $\mathrm{NaHCO}_{3}$ solution. The aqueous phase was extracted with EtOAc (x2). The combined organic phase was washed with brine, dried over anhydrous $\mathrm{MgSO}_{4}$, filtered, and concentrated under reduced pressure. The crude material was purified on a silica gel column ( 0 to $10 \%$ EtOAc in hexanes) to obtain $525 \mathrm{mg}$ of $\mathbf{2 0}$ (58\% yield) as colorless oil.

\section{Analytical data for compound 20:}

TLC: $\mathrm{R}_{\mathrm{f}}=0.42(10 \%$ EtOAc in hexanes $)$.

${ }^{1} \mathbf{H}$ NMR $\left(600 \mathrm{MHz}, \mathrm{CDCl}_{3}\right): \delta 7.28-7.26(\mathrm{~m}, 2 \mathrm{H}), 7.21-7.16(\mathrm{~m}, 3 \mathrm{H}), 3.04-3.00(\mathrm{~m}$, $1 \mathrm{H}), 2.94-2.76(\mathrm{~m}, 4 \mathrm{H}), 2.18(\mathrm{dd}, J=14.8,7.8 \mathrm{~Hz}, 1 \mathrm{H}), 2.02-1.95$ (m, 2H), 1.87-1.80 $(\mathrm{m}, 2 \mathrm{H}), 1.76(\mathrm{t}, J=2.5 \mathrm{~Hz}, 3 \mathrm{H}), 1.71-1.68(\mathrm{~m}, 1 \mathrm{H}), 1.46-1.38(\mathrm{~m}, 3 \mathrm{H}), 1.36(\mathrm{~s}, 3 \mathrm{H})$, $1.34-1.24(\mathrm{~m}, 2 \mathrm{H})$.

${ }^{13}$ C NMR (150 MHz, $\left.\mathrm{CDCl}_{3}\right): \delta 215.39(\mathrm{C}), 210.35(\mathrm{C}), 141.59(\mathrm{C}), 128.46(\mathrm{CH}), 128.41$ $(\mathrm{CH}), 125.96(\mathrm{CH}), 78.46(\mathrm{C}), 76.33(\mathrm{C}), 64.11(\mathrm{C}), 47.87(\mathrm{CH}), 42.79\left(\mathrm{CH}_{2}\right), 34.36$ $\left(\mathrm{CH}_{2}\right), 33.57\left(\mathrm{CH}_{2}\right), 31.34\left(\mathrm{CH}_{2}\right), 30.23\left(\mathrm{CH}_{2}\right), 29.98\left(\mathrm{CH}_{2}\right), 25.70\left(\mathrm{CH}_{2}\right), 22.78\left(\mathrm{CH}_{3}\right)$, $16.78\left(\mathrm{CH}_{2}\right), 3.46\left(\mathrm{CH}_{3}\right)$. 
IR (neat, $\mathrm{cm}^{-1}$ ): 3085 (w), 3061 (w), 3027 (m), 2929 (s), 2855 (s), 1737 (s), 1697 (s), 1604 (w), 1496 (m), 1454 (s), 1374 (s), 1242 (m), 1189 (w), 1047 (m), 940 (m), 750 (m), 700 (s).

HRMS (ESI-TOF) (m/z): $[\mathrm{M}+\mathrm{H}]^{+}$calcd for $\mathrm{C}_{22} \mathrm{H}_{29} \mathrm{O}_{2} 325.2168$; found, 325.2165.

Structure Determination: The structure of 20 was determined by ${ }^{1} \mathrm{H}$ and ${ }^{13} \mathrm{C}$ NMR. The relative stereochemistry was assigned based on NOESY analysis.

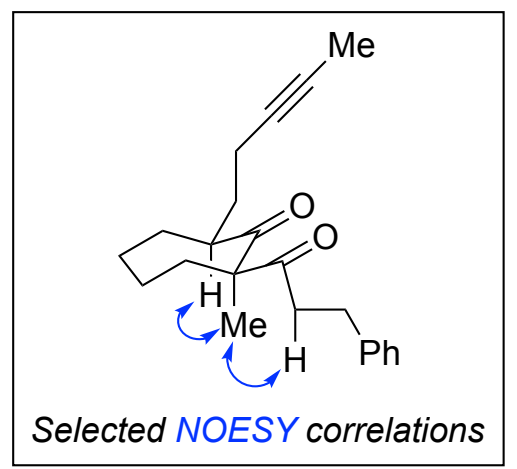

(6) Synthesis of additional Substrate 23

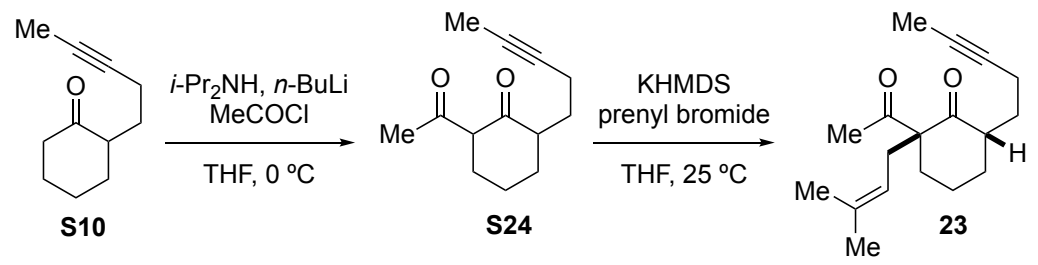

Using a modified procedure, ${ }^{6}$ to a stirring solution of diisopropylamine $(535 \mu \mathrm{L}$, $3.8 \mathrm{mmol}, 1.25$ equiv) in dry THF $(6 \mathrm{~mL})$ at $-78{ }^{\circ} \mathrm{C}$, was added $n$-BuLi $(1.7 \mathrm{~mL}, 3.65$ $\mathrm{mmol}, 2.18 \mathrm{M}$ in hexanes, 1.2 equiv). After, stirring for $45 \mathrm{~min}$, a solution of $\mathbf{S 1 0}$ (500 $\mathrm{mg}, 3.04 \mathrm{mmol}, 1.0$ equiv) in dry THF ( $8 \mathrm{~mL}$, additional $2 \mathrm{~mL}$ wash) was added dropwise. After $1 \mathrm{~h}$, the generated enolate was transferred to a precooled solution of acetyl chloride ( $282 \mu \mathrm{L}, 3.96 \mathrm{mmol}, 1.3$ equiv) in $4 \mathrm{~mL}$ dry THF, and the stirring was continued for $2 \mathrm{~h}$. The reaction was quenched with an aqueous saturated $\mathrm{NaHCO}_{3}$ solution at $-78{ }^{\circ} \mathrm{C}$ and the solution was allowed to warm up to room temperature. The layers were separated and the aqueous phase was extracted with ethyl acetate (x 2). The combined organic phase was washed with brine, dried over anhydrous $\mathrm{MgSO}_{4}$, filtered, and concentrated under reduced pressure to obtain crude $\mathbf{S 2 4}$ as light yellow oil, which was used in the next step without further purification.

Using a modified procedure, ${ }^{6}$ KHMDS (6.4 mL, $3.2 \mathrm{mmol}, 0.5 \mathrm{M}$ in PhMe, 1.05 equiv) was added dropwise to a solution of crude $\mathbf{S 2 4}$ in dry THF $(9 \mathrm{~mL})$ at room 
temperature. After 30 min, prenyl bromide $(0.46 \mathrm{~mL}, 3.96 \mathrm{mmol}, 1.3$ equiv) was added dropwise and stirring was continued for $5 \mathrm{~h}$. The reaction was quenched by addition of 6 $\mathrm{mL}$ aqueous saturated $\mathrm{NaHCO}_{3}$ solution. The aqueous phase was extracted with EtOAc (x2). The combined organic phase was washed with brine, dried over anhydrous MgSO4, filtered, and concentrated under reduced pressure. The crude material was purified on a silica gel column ( 0 to $10 \%$ EtOAc in hexanes) to obtain $\mathbf{2 3}$ (140 $\mathrm{mg}, 17 \%$ over 2 steps) as colorless oil.

\section{Analytical data for compound 23:}

TLC: $\mathrm{R}_{\mathrm{f}}=0.31$ (10\% EtOAc in hexanes).

${ }^{1} \mathbf{H}$ NMR $\left(600 \mathrm{MHz}, \mathrm{C}_{6} \mathrm{D}_{6}\right): \delta 5.00-4.98(\mathrm{~m}, 1 \mathrm{H}), 2.58-2.44(\mathrm{~m}, 3 \mathrm{H}), 2.20-2.08(\mathrm{~m}, 2 \mathrm{H})$, $2.04(\mathrm{~s}, 3 \mathrm{H}), 2.02-1.94(\mathrm{~m}, 2 \mathrm{H}), 1.59-1.55(\mathrm{~m}, 2 \mathrm{H}), 1.55(\mathrm{t}, 3 \mathrm{H}, J=2.5 \mathrm{~Hz}), 1.52(\mathrm{~s}$, $3 \mathrm{H}), 1.48(\mathrm{~s}, 3 \mathrm{H}), 2.42-1.37(\mathrm{~m}, 2 \mathrm{H}), 1.28-1.22(\mathrm{~m}, 1 \mathrm{H}), 1.01-0.94(\mathrm{~m}, 1 \mathrm{H})$.

${ }^{13}$ C NMR (150 MHz, $\left.\mathrm{C}_{6} \mathrm{D}_{6}\right)$ : $\delta 211.49(\mathrm{C}), 205.68(\mathrm{C}), 134.33(\mathrm{C}), 118.65(\mathrm{CH}), 78.60$ $(\mathrm{C}), 75.76(\mathrm{C}), 65.99(\mathrm{C}), 46.40(\mathrm{CH}), 32.25\left(\mathrm{CH}_{2}\right), 31.89\left(\mathrm{CH}_{2}\right), 31.26\left(\mathrm{CH}_{2}\right), 28.99$ $\left(\mathrm{CH}_{2}\right), 27.22\left(\mathrm{CH}_{3}\right), 25.50\left(\mathrm{CH}_{3}\right), 20.22\left(\mathrm{CH}_{2}\right), 17.60\left(\mathrm{CH}_{3}\right), 16.47\left(\mathrm{CH}_{2}\right), 3.04\left(\mathrm{CH}_{3}\right)$.

IR (neat, $\left.\mathrm{cm}^{-1}\right)$ : 2922 (s), 2860 (m), 1712 (s), 1698 (s), 1446 (m), 1372 (w), 1353 (m), $1167(\mathrm{w}), 1121(\mathrm{w})$.

HRMS (ESI-TOF) (m/z): [M + H] calcd for $\mathrm{C}_{18} \mathrm{H}_{27} \mathrm{O}_{2}$ 275.2011; found, 275.2016.

Structure Determination: The structure of $\mathbf{2 3}$ was determined by ${ }^{1} \mathrm{H}$ and ${ }^{13} \mathrm{C}$ NMR. The relative stereochemistry was assigned based on HSQC, COSY, and NOESY analysis. ${ }^{7}$

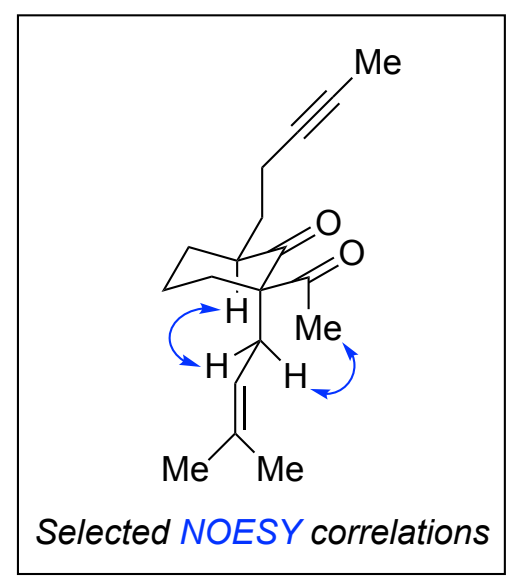




\section{Synthesis of Polycyclic Carbocycles by Ti-mediated Annulation Reaction}

\section{- Representative Procedure for Alkyne-Diketone Coupling Reaction}

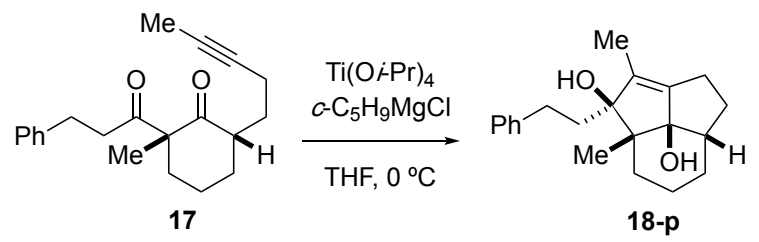

To a stirred solution of $17\left(380 \mathrm{mg}, 1.22 \mathrm{mmol}, 1.0\right.$ equiv) and $\mathrm{Ti}(\mathrm{O} i-\mathrm{Pr})_{4}(760$ $\mu \mathrm{L}, 2.57 \mathrm{mmol}, 2.1$ equiv) in $13 \mathrm{~mL}$ dry THF at $0{ }^{\circ} \mathrm{C}$ was added cyclopentylmagnesium chloride solution $\left(2.9 \mathrm{~mL}, 5.14 \mathrm{mmol}, 1.80 \mathrm{M}\right.$ in $\mathrm{Et}_{2} \mathrm{O}, 4.2$ equiv) dropwise. After complete consumption of starting material ( $\sim 10$ minutes), the reaction is quenched with a half-saturated aq. $\mathrm{NaHCO}_{3}$ solution $(15 \mathrm{~mL})$ and stirred for $1 \mathrm{~h}$ at room temperature. The biphasic mixture was filtered through a plug of celite and the celite-cake was washed with ethyl acetate $(10 \mathrm{~mL} \times 2)$. The layers were separated and the aqueous phase was extracted with ethyl acetate $(5 \mathrm{~mL} \times 2)$. The combined organic phase was washed with brine, dried over anhydrous $\mathrm{Na}_{2} \mathrm{SO}_{4}$, filtered, and concentrated under reduced pressure. The crude was purified on Biotage 25G KP-Sil column to obtain $214 \mathrm{mg}$ 18-p (56\% yield) as white solid.

- Alkyne-1,5-diketone Annulation Reactions

(1) Construction of Hydrazulene Ring System - Synthesis of 6

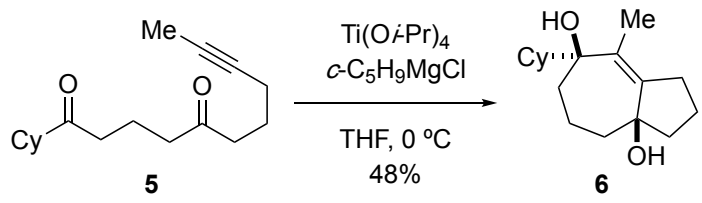

To a stirred solution of 5 (29.0 $\mathrm{mg}, 0.11 \mathrm{mmol}, 1.0$ equiv) in $4 \mathrm{~mL}$ dry THF was added $\mathrm{Ti}(\mathrm{O} i-\mathrm{Pr})_{4}\left(69 \mu \mathrm{L}, 0.232 \mathrm{mmol}, 2.1\right.$ equiv) at $0{ }^{\circ} \mathrm{C}$. Cyclopentylmagnesium chloride ( $228 \mu \mathrm{L}, 0.464 \mathrm{mmol}, 1.80 \mathrm{M}^{\text {in }} \mathrm{Et}_{2} \mathrm{O}, 4.2$ equiv) was added dropwise. After 30 min, reaction is quenched with a half-saturated aq. $\mathrm{NaHCO}_{3}$ solution and stirred for an additional $30 \mathrm{~min}$. The biphasic mixture was filtered through a plug of celite. The layers were separated and the aqueous phase was extracted with $2 \mathrm{~mL}$ ethyl acetate (x 2). The combined organic phase was washed with brine, dried over anhydrous $\mathrm{Na}_{2} \mathrm{SO}_{4}$, filtered, and concentrated under reduced pressure. The crude was purified on a silica gel column (Biotage SNAP Ultra 10G column) to afford $14.1 \mathrm{mg} 6$ (48\% yield) as colorless oil. 


\section{Analytical data for compound 6:}

TLC: $\mathrm{R}_{\mathrm{f}}=0.29(33 \%$ EtOAc in hexanes).

${ }^{1}$ H NMR $\left(600 \mathrm{MHz}, \mathrm{C}_{6} \mathrm{D}_{6}\right): \delta 2.75$ (brs, 2H), 2.41-2.36 (m, 1H), 2.20-2.13 (m, 1H), 2.11-2.06 (m, 1H), 2.00-1.95 (m, 2H), 1.93-1.90 (m, 1H), 1.86-1.72 (m, 4H), $1.71(\mathrm{~s}$, $3 \mathrm{H}), 1.71-1.64(\mathrm{~m}, 2 \mathrm{H}), 1.55-1.44(\mathrm{~m}, 6 \mathrm{H}), 1.30-1.10(\mathrm{~m}, 4 \mathrm{H}), 1.04(\mathrm{ddd}, J=24.6$, 12.6, $3.0 \mathrm{~Hz}, 1 \mathrm{H})$.

${ }^{13}$ C NMR (150 MHz, $\left.\mathrm{C}_{6} \mathrm{D}_{6}\right): \delta 144.82(\mathrm{C}), 137.23(\mathrm{C}), 79.86(\mathrm{C}), 77.42(\mathrm{C}), 46.53(\mathrm{CH})$, $45.21\left(\mathrm{CH}_{2}\right), 37.96\left(\mathrm{CH}_{2}\right), 35.14\left(\mathrm{CH}_{2}\right), 33.96\left(\mathrm{CH}_{2}\right), 29.13\left(\mathrm{CH}_{2}\right), 27.21\left(\mathrm{CH}_{2}\right), 26.95$ $\left(\mathrm{CH}_{2}\right), 21.72\left(\mathrm{CH}_{2}\right), 19.78\left(\mathrm{CH}_{2}\right), 17.84\left(\mathrm{CH}_{3}\right)$.

IR (neat, cm ${ }^{-1}$ ): 3398 (s, br), 3049 (w), 2931 (s), 2849 (s), 1641 (m), 1447 (s), 1260 (w), $1156(\mathrm{w}), 1031(\mathrm{w}), 934(\mathrm{~m}), 891(\mathrm{w}), 845(\mathrm{w}), 830(\mathrm{w}), 740(\mathrm{~m})$.

HRMS (ESI-TOF) (m/z): [M + Na $]^{+}$calcd for $\mathrm{C}_{17} \mathrm{H}_{28} \mathrm{O}_{2} \mathrm{Na}$ 287.1982; found, 287.1982.

\section{(2) Construction of 6-5-7 Fused Tricycles - Synthesis of 8 and 9}

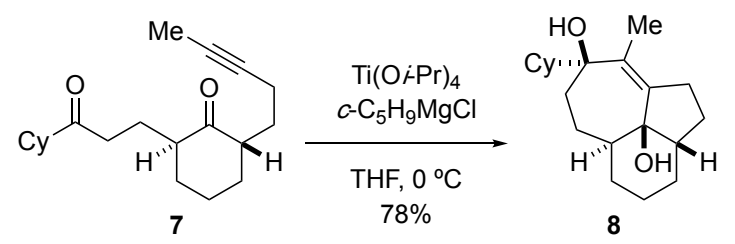

\section{Preparation of 8:}

To a stirred solution of 7 (31.0 mg, $0.102 \mathrm{mmol}, 1.0$ equiv) in $4 \mathrm{~mL}$ dry THF was added $\mathrm{Ti}(\mathrm{O} i \text {-Pr })_{4}(64 \mu \mathrm{L}, 0.215 \mathrm{mmol}, 2.1$ equiv $)$ at $0{ }^{\circ} \mathrm{C}$. Cyclopentylmagnesium chloride $\left(240 \mu \mathrm{L}, 0.430 \mathrm{mmol}, 1.80 \mathrm{M}\right.$ in $\mathrm{Et}_{2} \mathrm{O}, 4.2$ equiv) was added dropwise. After complete consumption of starting material ( $\sim 10$ minutes), reaction is quenched with a half-saturated aq. $\mathrm{NaHCO}_{3}$ solution and stirred for an additional $1 \mathrm{~h}$. The biphasic mixture was filtered through a plug of celite. The layers were separated and the aqueous phase was extracted with $2 \mathrm{~mL}$ ethyl acetate (x 2). The combined organic phase was washed with brine, dried over anhydrous $\mathrm{Na}_{2} \mathrm{SO}_{4}$, filtered, and concentrated under reduced pressure. The spectroscopically pure crude (quantitative crude yield) was purified on a basic alumina column to afford $24.5 \mathrm{mg} 8$ (78\% yield) as white solid.

\section{Analytical data for compound 8:}

TLC: $\mathrm{R}_{\mathrm{f}}=0.55$ (33\% EtOAc in hexanes). 
${ }^{1} \mathbf{H}$ NMR $\left(600 \mathrm{MHz}, \mathrm{C}_{6} \mathrm{D}_{6}\right): \delta 2.45-2.34(\mathrm{~m}, 2 \mathrm{H}), 2.27-2.25(\mathrm{~m}, 1 \mathrm{H}), 2.20-2.12(\mathrm{~m}, 2 \mathrm{H})$, $1.95-1.90(\mathrm{~m}, 2 \mathrm{H}), 1.87-1.77$ (m, 5H), 1.73-1.71 (m, 2H), 1.59-1.57 (m, 2H), 1.49-1.38 (m, 7H), 1.35-1.24 (m, 3H), 1.22-1.13 (m, 3H), 1.03-0.95 (m, 1H).

${ }^{13}$ C NMR ${ }^{13} \mathrm{C}$ NMR (150 MHz, $\left.\mathrm{C}_{6} \mathrm{D}_{6}\right): \delta 148.48(\mathrm{C}), 136.59(\mathrm{C}), 79.31$ (C), $76.10(\mathrm{C})$, $48.33(\mathrm{CH}), 47.17(\mathrm{CH}), 39.93\left(\mathrm{CH}_{2}\right), 34.40\left(\mathrm{CH}_{2}\right), 32.65\left(\mathrm{CH}_{2}\right), 30.54\left(\mathrm{CH}_{2}\right), 29.72$ $\left(\mathrm{CH}_{2}\right), 28.94\left(\mathrm{CH}_{2}\right), 27.35\left(\mathrm{CH}_{2}\right), 27.21\left(\mathrm{CH}_{2}\right), 26.88\left(\mathrm{CH}_{2}\right), 26.86\left(\mathrm{CH}_{2}\right), 26.69\left(\mathrm{CH}_{2}\right)$, $24.60\left(\mathrm{CH}_{2}\right), 21.49\left(\mathrm{CH}_{2}\right), 17.52\left(\mathrm{CH}_{3}\right)$.

IR (neat, $\mathrm{cm}^{-1}$ ): 3411 (br), 3213 (br), 2924 (s), 2853 (s), 1445 (s), 1264 (m), 1031 (w), $923(\mathrm{w}), 738(\mathrm{~m})$.

HRMS (ESI-TOF) (m/z): [M + Na $]^{+}$calcd for $\mathrm{C}_{20} \mathrm{H}_{32} \mathrm{O}_{2} \mathrm{Na}$ 327.2300; found, 327.2301.

Structure Determination: The structure of 8 was determined by ${ }^{1} \mathrm{H}$ and ${ }^{13} \mathrm{C}$ NMR. The structure and the relative stereochemistry were confirmed by single-crystal X-ray analysis. $^{7}$

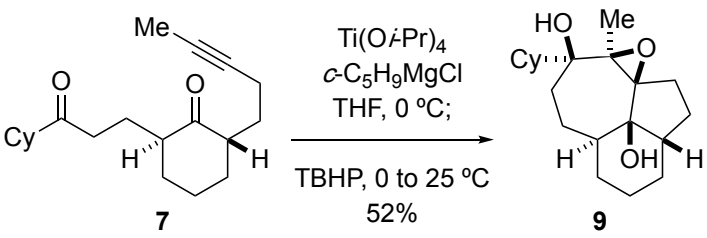

\section{Preparation of 9:}

To a stirred solution of 7 (20.0 $\mathrm{mg}, 0.066 \mathrm{mmol}, 1.0$ equiv) in $3 \mathrm{~mL}$ dry THF was added $\mathrm{Ti}(\mathrm{O} i-\mathrm{Pr})_{4}(41 \mu \mathrm{L}, 0.139 \mathrm{mmol}, 2.1$ equiv $)$ at $0{ }^{\circ} \mathrm{C}$. Cyclopentylmagnesium chloride $\left(154 \mu \mathrm{L}, 0.278 \mathrm{mmol}, 1.80 \mathrm{M}^{\text {in }} \mathrm{Et}_{2} \mathrm{O}, 4.2\right.$ equiv) was added dropwise. After complete consumption of starting material (10 min), TBHP $(120 \mu \mathrm{L}, 0.66 \mathrm{mmol}, 5.5 \mathrm{M}$ in nonane, 10 equiv) was added and the reaction mixture was warmed up to room temperature. After $1 \mathrm{~h}$, the reaction is quenched with a half-saturated aq. $\mathrm{NaHCO}_{3}$ solution and stirred for an additional $1 \mathrm{~h}$. The biphasic mixture was filtered through a plug of celite. The layers were separated and the aqueous phase was extracted with $2 \mathrm{~mL}$ ethyl acetate (x 2). The combined organic phase was washed with brine, dried over anhydrous $\mathrm{MgSO}_{4}$, filtered, and concentrated under reduced pressure. The crude was purified on Biotage 10G SNAP Ultra to obtain $11.1 \mathrm{mg} \mathbf{9}(52 \%$ yield $)$ as white solid.

\section{Analytical data for compound 9:}

TLC: $\mathrm{R}_{\mathrm{f}}=0.30$ (20\% EtOAc in hexanes). 
${ }^{1} \mathbf{H}$ NMR (600 MHz, $\mathrm{CDCl}_{3}$ ): $\delta 4.66$ (brs, 1H), 3.25 (brs, 1H), 2.33-2.29 (m, 1H), 2.22$2.18(\mathrm{~m}, 1 \mathrm{H}), 2.06-2.04(\mathrm{~m}, 1 \mathrm{H}), 1.83-1.75(\mathrm{~m}, 4 \mathrm{H}), 1.74-1.56(\mathrm{~m}, 6 \mathrm{H}), 1.51-1.44(\mathrm{~m}$, $3 \mathrm{H}), 1.43-1.38$ (m, 2H), 1.37-1.31 (m, 2H), 1.30-1.24 (m, 6H), 1.22-1.14 (m, 4H).

${ }^{13}$ C NMR (150 MHz, $\left.\mathrm{CDCl}_{3}\right): \delta 76.53(\mathrm{C}), 75.54(\mathrm{C}), 71.82(\mathrm{C}), 66.31(\mathrm{C}), 45.76(\mathrm{CH})$, $44.86(\mathrm{CH}), 38.90(\mathrm{CH}), 31.34\left(\mathrm{CH}_{2}\right), 30.18\left(\mathrm{CH}_{2}\right), 29.95\left(\mathrm{CH}_{2}\right), 28.17\left(\mathrm{CH}_{2}\right), 26.86$ $\left(\mathrm{CH}_{2}\right), 26.67\left(\mathrm{CH}_{2}\right), 26.64\left(\mathrm{CH}_{2}\right), 26.44\left(\mathrm{CH}_{2}\right), 26.41\left(\mathrm{CH}_{2}\right), 23.64\left(\mathrm{CH}_{2}\right), 22.05\left(\mathrm{CH}_{2}\right)$, $20.24\left(\mathrm{CH}_{2}\right), 18.42\left(\mathrm{CH}_{3}\right)$.

IR (neat, $\mathrm{cm}^{-1}$ ): 3328 (br), 3230 (br), 2958 (m), 2920 (s), 2881 (m), 2850 (s), 1460 (m), $1442(\mathrm{~m}), 1417$ (m), $1271(\mathrm{~m}), 1219(\mathrm{w}), 1125(\mathrm{w}), 846(\mathrm{w}), 735(\mathrm{~s})$.

HRMS (ESI-TOF) (m/z): $[\mathrm{M}+\mathrm{H}]^{+}$calcd for $\mathrm{C}_{20} \mathrm{H}_{33} \mathrm{O}_{3}$ 321.2430; found, 321.2424.

Structure Determination: The structure of 9 was determined by ${ }^{1} \mathrm{H}$ and ${ }^{13} \mathrm{C}$ NMR. The structure and the relative stereochemistry were confirmed by single-crystal X-ray analysis. $^{7}$

- Alkyne-1,4-diketone Annulation Reactions

(3) Construction of 6-5-6 Fused Tricycles - Synthesis of 13 and 14

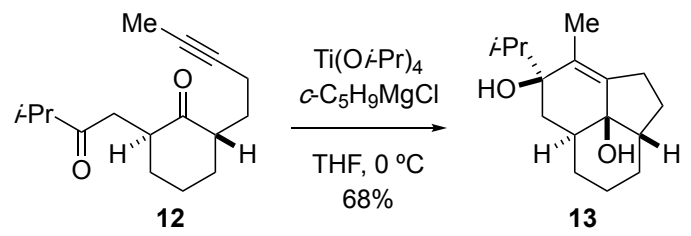

Preparation of 13:

To a stirred solution of 12 (24.5 $\mathrm{mg}, 0.099 \mathrm{mmol}, 1.0$ equiv) in $3 \mathrm{~mL}$ dry THF was added $\mathrm{Ti}(\mathrm{O} i \text {-Pr })_{4}(62 \mu \mathrm{L}, 0.207 \mathrm{mmol}, 2.1$ equiv $)$ at $0{ }^{\circ} \mathrm{C}$. Cyclopentylmagnesium chloride $\left(269 \mu \mathrm{L}, 0.414 \mathrm{mmol}, 1.54 \mathrm{M}\right.$ in $\mathrm{Et}_{2} \mathrm{O}, 4.2$ equiv) was added dropwise. After complete consumption of starting material ( $<15$ minutes), reaction is quenched with a half-saturated aq. $\mathrm{NaHCO}_{3}$ solution and stirred for an additional $1 \mathrm{~h}$. The biphasic mixture was filtered through a plug of celite. The layers were separated and the aqueous phase was extracted with $2 \mathrm{~mL}$ ethyl acetate (x 2). The combined organic phase was washed with brine, dried over anhydrous $\mathrm{Na}_{2} \mathrm{SO}_{4}$, filtered, and concentrated under reduced pressure. The crude was purified on a basic alumina column to afford $16.8 \mathrm{mg} \mathbf{1 3}$ (68\% yield) as colorless oil. It is important to note that compound $\mathbf{1 3}$ is unstable on a silica gel column. Initial attempts towards purification on a silica gel column (Biotage SNAP Ultra $10 \mathrm{G}$ column) led to isolation of the $\mathbf{1 3}$ in lower yield $(38 \%, 41 \%)$ due to partial decomposition. 


\section{Analytical data for compound 13:}

TLC: $\mathrm{R}_{\mathrm{f}}=0.22(33 \%$ EtOAc in hexanes).

${ }^{1} \mathbf{H}$ NMR $\left(600 \mathrm{MHz}, \mathrm{CDCl}_{3}\right): \delta 2.42$ (brs, 2H), 2.37-2.29 (m, 2H), 2.10-2.04 (m, 1H), 2.01-1.90 (m, 3H), 1.76-1.72 (m, 1H), $1.68(\mathrm{~s}, 3 \mathrm{H}), 1.61-1.55(\mathrm{~m}, 1 \mathrm{H}), 1.54-1.42(\mathrm{~m}$, $3 \mathrm{H}), 1.41-1.35(\mathrm{~m}, 1 \mathrm{H}), 1.32-1.27(\mathrm{~m}, 1 \mathrm{H}), 1.19-1.13(\mathrm{~m}, 1 \mathrm{H}), 1.06-0.99(\mathrm{~m}, 4 \mathrm{H}), 0.73$ $(\mathrm{d}, J=6.9 \mathrm{~Hz}, 3 \mathrm{H})$.

${ }^{13}$ C NMR (150 MHz, $\left.\mathrm{CDCl}_{3}\right): \delta 147.97(\mathrm{C}), 129.81(\mathrm{C}), 76.20(\mathrm{C}), 75.62(\mathrm{C}), 47.80$ $(\mathrm{CH}), 37.25(\mathrm{CH}), 34.19(\mathrm{CH}), 33.22\left(\mathrm{CH}_{2}\right), 31.68\left(\mathrm{CH}_{2}\right), 29.18\left(\mathrm{CH}_{2}\right), 26.10\left(\mathrm{CH}_{2}\right)$, $23.80\left(\mathrm{CH}_{2}\right), 20.50\left(\mathrm{CH}_{2}\right), 18.26\left(\mathrm{CH}_{3}\right), 15.96\left(\mathrm{CH}_{3}\right), 13.64\left(\mathrm{CH}_{3}\right)$.

IR (neat, $\mathrm{cm}^{-1}$ ): 3408 (br), 2941 (s), 2857 (s), 1700 (w), 1460 (m), 1376 (m), 1201 (w), $1035(\mathrm{w}), 979(\mathrm{~m}), 787(\mathrm{w}), 735(\mathrm{w})$.

HRMS (ESI-TOF) (m/z): [M + Na $]^{+}$calcd for $\mathrm{C}_{16} \mathrm{H}_{26} \mathrm{O}_{2} \mathrm{Na}$ 273.1830; found, 273.1832.

Structure Determination: The structure of 13 was determined by ${ }^{1} \mathrm{H}$ and ${ }^{13} \mathrm{C}$ NMR. The connectivity of atoms was supported by HSQC, HMBC, COSY, and NOESY analysis. The stereochemistry was assigned by analogy to the structure of 14 whose structure was confirmed by X-ray analysis. ${ }^{7}$
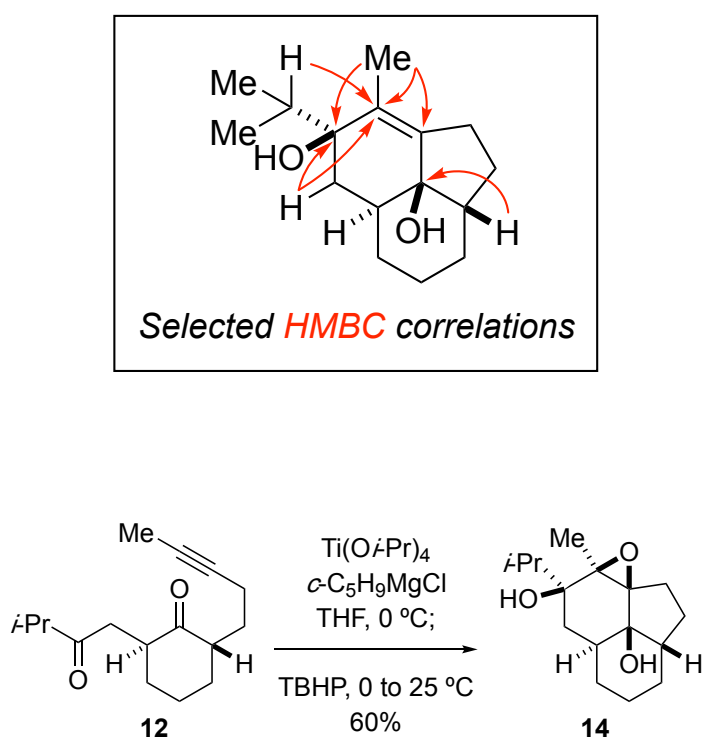

\section{Preparation of 14:}

To a stirred solution of 12 (16.6 mg, $0.067 \mathrm{mmol}, 1.0$ equiv) in $3 \mathrm{~mL}$ dry THF was added $\mathrm{Ti}(\mathrm{O} i \text {-Pr })_{4}(42 \mu \mathrm{L}, 0.140 \mathrm{mmol}, 2.1$ equiv $)$ at $0{ }^{\circ} \mathrm{C}$. Cyclopentylmagnesium chloride $\left(182 \mu \mathrm{L}, 0.281 \mathrm{mmol}, 1.54 \mathrm{M}\right.$ in $\mathrm{Et}_{2} \mathrm{O}, 4.2$ equiv) was added dropwise. After complete consumption of starting material (7 min), TBHP $(122 \mu \mathrm{L}, 0.67 \mathrm{mmol}, 5.5 \mathrm{M}$ in 
nonane, 10 equiv) was added and the reaction mixture was warmed up to room temperature. After $1 \mathrm{~h}$, the reaction is quenched with a half-saturated aq. $\mathrm{NaHCO}_{3}$ solution and stirred for an additional $1 \mathrm{~h}$. The biphasic mixture was filtered through a plug of celite. The layers were separated and the aqueous phase was extracted with $2 \mathrm{~mL}$ ethyl acetate (x 2). The combined organic phase was washed with brine, dried over anhydrous $\mathrm{MgSO}_{4}$, filtered, and concentrated under reduced pressure. The crude was purified on Biotage 10G SNAP Ultra to obtain $10.7 \mathrm{mg} 14$ (60\% yield) as white solid.

\section{Analytical data for compound 14:}

TLC: $\mathrm{R}_{\mathrm{f}}=0.26(33 \%$ EtOAc in hexanes $)$.

${ }^{1}$ H NMR $\left(600 \mathrm{MHz}, \mathrm{C}_{6} \mathrm{D}_{6}\right): \delta 2.43(\mathrm{~s}, 1 \mathrm{H}), 2.02-1.96(\mathrm{~m}, 1 \mathrm{H}), 1.82$ (sept, $J=6.8 \mathrm{~Hz}$, $1 \mathrm{H}), 1.68(\mathrm{dt}, J=13.5,6.7 \mathrm{~Hz}, 1 \mathrm{H}), 1.57-1.45(\mathrm{~m}, 5 \mathrm{H}), 1.41(\mathrm{dd}, J=13.1,5.9 \mathrm{~Hz}, 1 \mathrm{H})$, $1.36-1.32(\mathrm{~m}, 1 \mathrm{H}), 1.29-1.21(\mathrm{~m}, 1 \mathrm{H}), 1.08(\mathrm{~s}, 3 \mathrm{H}), 1.07-1.00(\mathrm{~m}, 2 \mathrm{H}), 0.94(\mathrm{~d}, J=6.7$ $\mathrm{Hz}, 3 \mathrm{H}), 0.81-0.70(\mathrm{~m}, 2 \mathrm{H}), 0.65(\mathrm{dq}, J=12.6,5.9 \mathrm{~Hz}, 1 \mathrm{H}), 0.49$ (d, $J=7.1 \mathrm{~Hz}, 3 \mathrm{H})$.

${ }^{13}$ C NMR (150 MHz, $\left.\mathrm{C}_{6} \mathrm{D}_{6}\right): \delta 79.34(\mathrm{C}), 74.85(\mathrm{C}), 72.45(\mathrm{C}), 69.40(\mathrm{C}), 46.36(\mathrm{CH})$, $34.42(\mathrm{CH}), 33.42(\mathrm{CH}), 30.48\left(\mathrm{CH}_{2}\right), 28.53\left(\mathrm{CH}_{2}\right), 26.53\left(\mathrm{CH}_{2}\right), 26.15\left(\mathrm{CH}_{2}\right), 22.83$ $\left(\mathrm{CH}_{2}\right), 19.93\left(\mathrm{CH}_{2}\right), 19.14\left(\mathrm{CH}_{3}\right), 16.66\left(\mathrm{CH}_{3}\right), 15.78\left(\mathrm{CH}_{3}\right)$.

IR (neat, cm ${ }^{-1}$ ): 3482 (br), 2944 (s), 2860 (s), 1460 (m), 1380 (w), 1309 (w), 1204 (w), $1103(\mathrm{w}), 1012(\mathrm{~m}), 991(\mathrm{~m}), 886(\mathrm{w})$.

HRMS (ESI-TOF) (m/z): [M + Na] $]^{+}$calcd for $\mathrm{C}_{16} \mathrm{H}_{26} \mathrm{O}_{3} \mathrm{Na} 289.1780$; found, 289.1779.

Structure Determination: The structure of 14 was determined by ${ }^{1} \mathrm{H}$ and ${ }^{13} \mathrm{C} N M R$. The connectivity of atoms was supported by HSQC, HMBC, COSY, and NOESY analysis. The structure of $\mathbf{1 4}$ was further confirmed by X-ray analysis. ${ }^{7}$

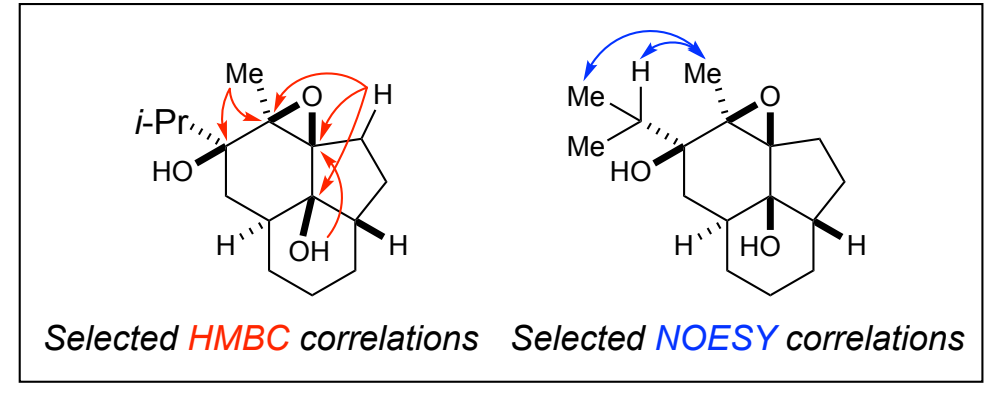




\section{(4) Construction of 5-5-6 Fused Tricycle - Synthesis of 16}

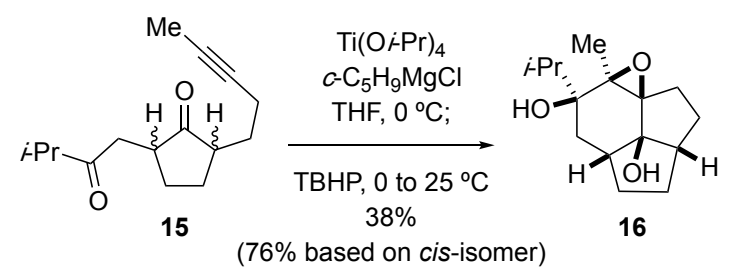

\section{Preparation of 16:}

To a stirred solution of $\mathbf{1 5}(\sim 1: 1 \mathrm{mixture}$ of diastereomers, $33.3 \mathrm{mg}, 0.142 \mathrm{mmol}$, 1.0 equiv) in $5 \mathrm{~mL}$ dry $\mathrm{THF}$ was added $\mathrm{Ti}(\mathrm{O} i \text {-Pr })_{4}(88 \mu \mathrm{L}, 0.298 \mathrm{mmol}, 2.1$ equiv $)$ at 0 ${ }^{\circ} \mathrm{C}$. Cyclopentylmagnesium chloride $(388 \mu \mathrm{L}, 0.597 \mathrm{mmol}, 4.2 \mathrm{equiv})$ was added dropwise. After complete consumption of starting material ( $<10$ minutes), TBHP $(0.26$ $\mathrm{mL}, 1.42 \mathrm{mmol}, 5.5 \mathrm{M}$ in nonane, 10 equiv) was added and the reaction mixture was warmed up to room temperature. After $1 \mathrm{~h}$, the reaction is quenched with a half-saturated aq. $\mathrm{NaHCO}_{3}$ solution and stirred for an additional $1 \mathrm{~h}$. The biphasic mixture was filtered through a plug of celite. The layers were separated and the aqueous phase was extracted with $2 \mathrm{~mL}$ ethyl acetate (x 2). The combined organic phase was washed with brine, dried over anhydrous $\mathrm{MgSO}_{4}$, filtered, and concentrated under reduced pressure. The crude was purified on Biotage 10G SNAP Ultra to obtain $13.8 \mathrm{mg} 16(38 \%$, or $\sim 76 \%$ from cis $\mathbf{1 5})$ as colorless oil which solidified when refrigerated.

\section{Analytical data for compound 16:}

TLC: $\mathrm{R}_{\mathrm{f}}=0.28(33 \%$ EtOAc in hexanes).

${ }^{1}$ H NMR $\left(600 \mathrm{MHz}, \mathrm{CDCl}_{3}\right): \delta 2.98(\mathrm{~s}, 1 \mathrm{H}), 2.56-2.51(\mathrm{~m}, 1 \mathrm{H}), 2.22(\mathrm{~d}, J=13.6,7.6$ $\mathrm{Hz}, 1 \mathrm{H}), 2.18(\mathrm{~s}, 1 \mathrm{H}), 2.11-2.02(\mathrm{~m}, 2 \mathrm{H}), 2.00-1.96(\mathrm{~m}, 1 \mathrm{H}), 1.95-1.88(\mathrm{~m}, 3 \mathrm{H}), 1.87-$ $1.81(\mathrm{~m}, 1 \mathrm{H}), 1.43-1.38(\mathrm{~m}, 1 \mathrm{H}), 1.37(\mathrm{~s}, 3 \mathrm{H}), 1.29-1.24(\mathrm{~m}, 1 \mathrm{H}), 1.20-1.13(\mathrm{~m}, 1 \mathrm{H})$, $1.03(\mathrm{~d}, J=6.5 \mathrm{~Hz}, 3 \mathrm{H}), 0.97(\mathrm{~d}, J=6.6 \mathrm{~Hz}, 3 \mathrm{H}), 0.80(\mathrm{dd}, J=13.5,9.5 \mathrm{~Hz}, 1 \mathrm{H})$.

${ }^{13}$ C NMR (150 MHz, $\left.\mathrm{CDCl}_{3}\right): \delta 83.79(\mathrm{C}), 74.47(\mathrm{C}), 70.37(\mathrm{C}), 66.81(\mathrm{C}), 52.60(\mathrm{CH})$, $45.22(\mathrm{CH}), 36.50\left(\mathrm{CH}_{2}\right), 33.31\left(\mathrm{CH}_{2}\right), 32.86(\mathrm{CH}), 28.84\left(\mathrm{CH}_{2}\right), 28.77\left(\mathrm{CH}_{2}\right), 25.81$ $\left(\mathrm{CH}_{2}\right), 17.97\left(\mathrm{CH}_{3}\right), 17.32\left(\mathrm{CH}_{3}\right), 15.88\left(\mathrm{CH}_{3}\right)$.

IR (neat, $\mathrm{cm}^{-1}$ ): 3438 (br), 2954 (s), 2869 (s), 1715 (m), 1457 (m), 1380 (m), 1306 (w), $1045(\mathrm{~m}), 1011(\mathrm{~m})$.

HRMS (ESI-TOF) (m/z): [M + H]+ calcd for $\mathrm{C}_{15} \mathrm{H}_{25} \mathrm{O}_{3}$ 253.1804; found, 253.1807.

Structure Determination: The structure of 16 was determined by ${ }^{1} \mathrm{H}$ and ${ }^{13} \mathrm{C} N M R$. The relative stereochemistry was assigned based on HSQC, HMBC, COSY, and NOESY analysis. The structure was further confirmed by single-crystal X-ray analysis. ${ }^{7}$ 


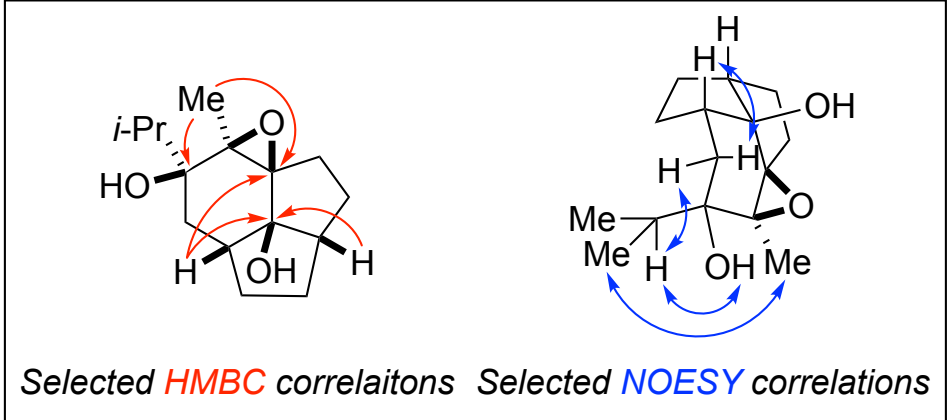

- Alkyne-1,3-diketone Annulation Reactions

(5) Construction of 6-5-5 Fused Tricycles - Synthesis of compounds including 18 \& 19

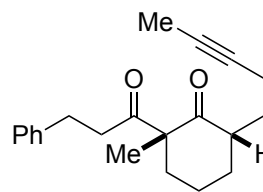

17
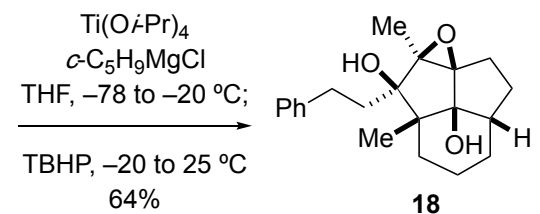

18

\section{Preparation of 18:}

To a stirred solution of $\mathrm{Ti}(\mathrm{O} i-\mathrm{Pr})_{4}(74 \mu \mathrm{L}, 0.247 \mathrm{mmol}, 2.1$ equiv $)$ in $3 \mathrm{~mL}$ dry THF at $-78{ }^{\circ} \mathrm{C}$ was dropwise added cyclopentylmagnesium chloride (332 $\mu \mathrm{L}, 0.494$ mmol, 4.2 equiv). After $30 \mathrm{~min}$, a solution of 17 (36.5 mg, $0.118 \mathrm{mmol}, 1.0$ equiv) in 5 $\mathrm{mL}$ dry THF (additional $1 \mathrm{~mL}$ wash) was added dropwise and the reaction mixture was warmed to $-20{ }^{\circ} \mathrm{C}$. After $90 \mathrm{~min}$, TBHP $(214 \mu \mathrm{L}, 1.18 \mathrm{mmol}, 5.5 \mathrm{M}$ in nonane, 10 equiv $)$ was added and the mixture was stirred for $2 \mathrm{~h}$ at room temperature. The reaction was quenched by addition $2 \mathrm{~mL}$ aq. $\mathrm{HCl}(1 \mathrm{M})$ solution at $-20{ }^{\circ} \mathrm{C}$, and stirred at room temperature for $30 \mathrm{~min}$ where two clear layers were observed. The layers were separated and the aqueous phase was extracted with $2 \mathrm{~mL}$ ethyl acetate (x 2). The combined organic phase was washed with sat. aq. $\mathrm{NaHCO}_{3}$ solution followed by brine, dried over anhydrous $\mathrm{MgSO}_{4}$, filtered, and concentrated under reduced pressure. The crude was purified on Biotage 10G SNAP Ultra to obtain $24.8 \mathrm{mg} 18$ (64\% yield) as white solid.

\section{Analytical data for compound 18:}

TLC: $\mathrm{R}_{\mathrm{f}}=0.39(33 \%$ EtOAc in hexanes $)$.

${ }^{1}$ H NMR $\left(600 \mathrm{MHz}, \mathrm{CDCl}_{3}\right): \delta 7.30-7.28(\mathrm{~m}, 2 \mathrm{H}), 7.22-7.18(\mathrm{~m}, 3 \mathrm{H}), 2.86-2.75(\mathrm{~m}$, $2 \mathrm{H}), 2.80(\mathrm{~s}, 1 \mathrm{H}), 2.30-2.24(\mathrm{~m}, 1 \mathrm{H}), 2.13(\mathrm{~s}, 1 \mathrm{H}), 2.09-2.00(\mathrm{~m}, 2 \mathrm{H}), 1.93-1.88(\mathrm{~m}$, $1 \mathrm{H}), 1.85-1.77(\mathrm{~m}, 2 \mathrm{H}), 1.74-1.69(\mathrm{~m}, 1 \mathrm{H}), 1.57-1.46(\mathrm{~m}, 3 \mathrm{H}), 1.48(\mathrm{~s}, 3 \mathrm{H}), 1.44-$ $1.37(\mathrm{~m}, 1 \mathrm{H}), 1.15-1.09(\mathrm{~m}, 1 \mathrm{H}), 1.04(\mathrm{~s}, 3 \mathrm{H}), 0.98(\mathrm{td}, J=12.9,4.2 \mathrm{~Hz})$. 
${ }^{13}$ C NMR $\left(150 \mathrm{MHz}, \mathrm{CDCl}_{3}\right): \delta 142.98(\mathrm{C}), 128.47(\mathrm{CH}), 128.32(\mathrm{CH}), 125.84(\mathrm{CH})$, 84.49 (C), 83.98 (C), 83.75 (C), 73.39 (C), 54.34 (C), 43.29 (CH), $35.49\left(\mathrm{CH}_{2}\right), 31.90$ $\left(\mathrm{CH}_{2}\right), 30.98\left(\mathrm{CH}_{2}\right), 30.44\left(\mathrm{CH}_{2}\right), 26.37\left(\mathrm{CH}_{2}\right), 23.63\left(\mathrm{CH}_{2}\right), 18.18\left(\mathrm{CH}_{2}\right), 14.80\left(\mathrm{CH}_{3}\right)$, $14.43\left(\mathrm{CH}_{3}\right)$.

IR (neat, $\mathrm{cm}^{-1}$ ): 3502 (br), 3060 (w), 3024 (m), 2937 (s), 2868 (s), $1711(\mathrm{w}), 1605$ (w), 1495 (m), 1452 (s), 1379 (s), 1327 (m), 1115 (m), 1100 (m), 1038 (s), 899 (m), 738 (s), 700 (s).

HRMS (ESI-TOF) (m/z): [M + H] calcd for $\mathrm{C}_{21} \mathrm{H}_{29} \mathrm{O}_{3}$ 329.2117; found, 329.2116.

Structure Determination: The structure of 18 was determined by ${ }^{1} \mathrm{H}$ and ${ }^{13} \mathrm{C} N M R$. The relative stereochemistry was assigned based on HSQC, HMBC, and NOESY analysis. The structure was further supported by X-ray. ${ }^{7}$
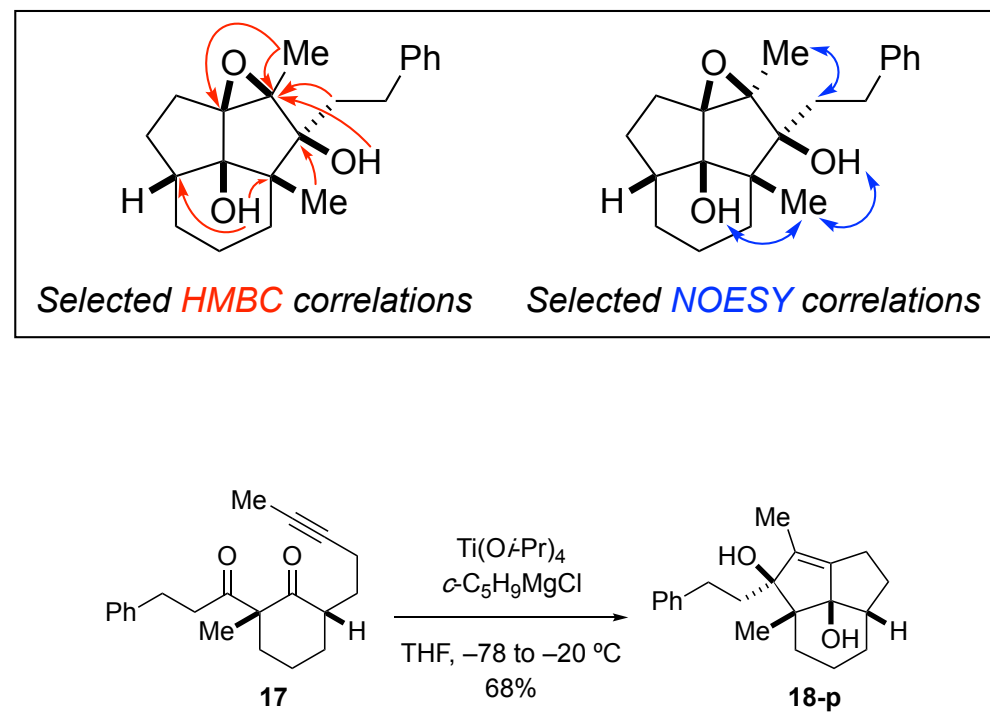

\section{Preparation of 18-p:}

To a stirred solution of $\mathrm{Ti}(\mathrm{O} i-\mathrm{Pr})_{4}(105 \mu \mathrm{L}, 0.352 \mathrm{mmol}, 2.1$ equiv) in $3 \mathrm{~mL}$ dry THF at $-78{ }^{\circ} \mathrm{C}$ was dropwise added cyclopentylmagnesium chloride $(419 \mu \mathrm{L}, 0.704$ mmol, 4.2 equiv). After $30 \mathrm{~min}$, a solution of $17(52.0 \mathrm{mg}, 0.168 \mathrm{mmol}, 1.0$ equiv) in 5 $\mathrm{mL}$ dry THF (additional $1 \mathrm{~mL}$ wash) was added dropwise. The reaction mixture was warmed to $-20{ }^{\circ} \mathrm{C}$ and stirred for $75 \mathrm{~min}$. The reaction was quenched by addition of a half-saturated aq. $\mathrm{NaHCO}_{3}$ solution at $-20{ }^{\circ} \mathrm{C}$, and stirred at room temperature for $1 \mathrm{~h}$. The biphasic mixture was filtered through a plug of celite. The layers were separated and the aqueous phase was extracted with $2 \mathrm{~mL}$ ethyl acetate (x 2). The combined organic phase was washed with brine, dried over anhydrous $\mathrm{MgSO}_{4}$, filtered, and concentrated under reduced pressure. The crude was purified on Biotage 10G SNAP Ultra to obtain $35.4 \mathrm{mg} \mathrm{18-p} \mathrm{(68 \%} \mathrm{yield)} \mathrm{as} \mathrm{colorless} \mathrm{oil} \mathrm{which} \mathrm{solidifies} \mathrm{over} \mathrm{time.} \mathrm{In} \mathrm{a} 1.22 \mathrm{mmol}$ 
scale reaction, 18-p was isolated in 56\% yield (see representative procedure for detailed procedure).

\section{Analytical data for compound 18-p:}

TLC: $\mathrm{R}_{\mathrm{f}}=0.24(20 \%$ EtOAc in hexanes $)$.

${ }^{1}$ H NMR $\left(600 \mathrm{MHz}^{\mathrm{CDCl}}{ }_{3}\right): \delta 7.31-7.28(\mathrm{~m}, 2 \mathrm{H}), 7.23-7.22(\mathrm{~m}, 2 \mathrm{H}), 7.20-7.18(\mathrm{~m}$, $1 \mathrm{H}), 2.89(\mathrm{td}, J=13.2,4.8 \mathrm{~Hz}, 1 \mathrm{H}), 2.79(\mathrm{td}, J=12.6,5.4 \mathrm{~Hz}, 1 \mathrm{H}), 2.51(\mathrm{~s}, 1 \mathrm{H}), 2.43-$ $2.36(\mathrm{~m}, 1 \mathrm{H}), 2.32-2.27(\mathrm{~m}, 1 \mathrm{H}), 2.22-2.16(\mathrm{~m}, 1 \mathrm{H}), 2.06(\mathrm{~s}, 1 \mathrm{H}), 1.89(\mathrm{ddd}, J=14.2$, 12.7, $5.3 \mathrm{~Hz}, 1 \mathrm{H}), 1.82-1.74(\mathrm{~m}, 2 \mathrm{H}), 1.68(\mathrm{t}, J=1.8 \mathrm{~Hz}, 3 \mathrm{H}), 1.68-1.60(\mathrm{~m}, 3 \mathrm{H})$, $1.46-1.42(\mathrm{~m}, 1 \mathrm{H}), 1.32$ (qt, $J=13.4,2.6 \mathrm{~Hz}, 1 \mathrm{H}), 1.25(\mathrm{~s}, 3 \mathrm{H}), 1.12(\mathrm{td}, J=13.2,2.4$ $\mathrm{Hz}, 1 \mathrm{H}), 0.77$ (ddd, $J=25.7,13.3,3.1 \mathrm{~Hz}, 1 \mathrm{H})$.

${ }^{13}$ C NMR (150 MHz, $\left.\mathrm{CDCl}_{3}\right): \delta 148.56(\mathrm{C}), 143.24(\mathrm{C}), 136.55(\mathrm{C}), 128.43(\mathrm{CH}), 128.34$ $(\mathrm{CH}), 125.76(\mathrm{CH}), 93.18(\mathrm{C}), 93.11(\mathrm{C}), 48.92(\mathrm{C}), 41.89(\mathrm{CH}), 35.45\left(\mathrm{CH}_{2}\right), 35.44$ $\left(\mathrm{CH}_{2}\right), 32.94\left(\mathrm{CH}_{2}\right), 30.31\left(\mathrm{CH}_{2}\right), 29.51\left(\mathrm{CH}_{2}\right), 21.14\left(\mathrm{CH}_{2}\right), 19.91\left(\mathrm{CH}_{2}\right), 15.78\left(\mathrm{CH}_{3}\right)$, $11.92\left(\mathrm{CH}_{3}\right)$.

IR (neat, $\mathrm{cm}^{-1}$ ): 3367 (br), 3086 (w), 3059 (w), 3024 (m), 2933 (s), 2960 (s), 1702 (m), 1604 (w), 1496 (m), 1446 (m), 1401 (m), 1376 (m), 1324 (w), $1274(\mathrm{w}), 1086(\mathrm{~m}), 1015$ (m), $911(\mathrm{~m}), 841(\mathrm{w}), 742(\mathrm{~m}), 701(\mathrm{~m})$.

HRMS (ESI-TOF) (m/z): $[\mathrm{M}+\mathrm{Na}]^{+}$calcd for $\mathrm{C}_{21} \mathrm{H}_{28} \mathrm{O}_{2} \mathrm{Na}$ 335.1987; found, 335.1987.

Structure Determination: The structure of 18-p was determined by ${ }^{1} \mathrm{H}$ and ${ }^{13} \mathrm{C}$ NMR. The relative stereochemistry was assigned based on HSQC, HMBC, and NOESY analysis. $^{7}$

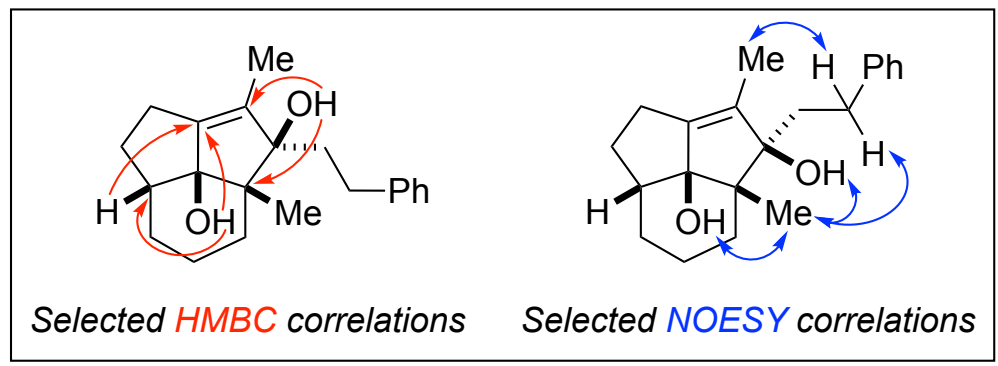




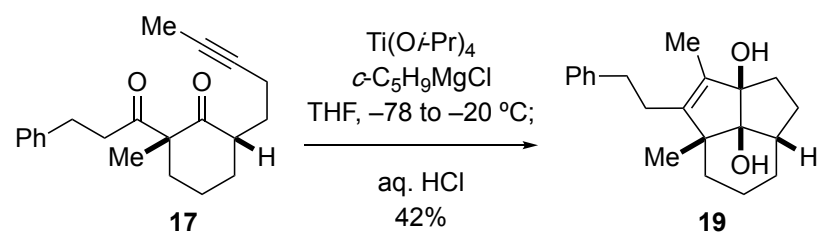

\section{Preparation of 19:}

To a stirred solution of $\operatorname{Ti}(\mathrm{O} i \text {-Pr })_{4}(105 \mu \mathrm{L}, 0.353 \mathrm{mmol}, 2.1$ equiv) in $4 \mathrm{~mL}$ dry THF at $-78{ }^{\circ} \mathrm{C}$ was dropwise added cyclopentylmagnesium chloride $(460 \mu \mathrm{L}, 0.706$ mmol, 4.2 equiv). After $30 \mathrm{~min}$, a solution of $17(52.1 \mathrm{mg}, 0.168 \mathrm{mmol}, 1.0$ equiv) in 6 $\mathrm{mL}$ dry THF (additional $2 \mathrm{~mL}$ wash) was added dropwise and the reaction mixture was warmed to $-20^{\circ} \mathrm{C}$. After $2 \mathrm{~h}$, the reaction was quenched by addition $3.4 \mathrm{~mL}$ aq. $\mathrm{HCl}$ (1 M) solution at $-20{ }^{\circ} \mathrm{C}$, and stirred at $0{ }^{\circ} \mathrm{C}$ for $2.5 \mathrm{~h}$. The TLC clearly showed the transformation of initially formed compound to a more polar compound over time. The layers were separated and the aqueous phase was extracted with $2 \mathrm{~mL}$ ethyl acetate (x 2). The combined organic phase was washed with water, sat. aq. $\mathrm{NaHCO}_{3}$ solution, followed by brine, dried over anhydrous $\mathrm{Na}_{2} \mathrm{SO}_{4}$, filtered, and concentrated under reduced pressure. The crude was purified on a basic alumina column to afford $22 \mathrm{mg} 19$ (42\% yield) as colorless oil. It is important to note that compound 19 is unstable on a silica gel column. Initial attempt towards purification on a silica gel column (Biotage SNAP Ultra $10 \mathrm{G}$ column) led to isolation of the 19 in lower yield (32\%) due to partial decomposition.

\section{Analytical data for compound 19:}

TLC: $\mathrm{R}_{\mathrm{f}}=0.23(33 \%$ EtOAc in hexanes).

${ }^{1}$ H NMR (600 MHz, $\left.\mathrm{C}_{6} \mathrm{D}_{6}\right): \delta 7.19-7.17(\mathrm{~m}, 2 \mathrm{H}), 7.11-7.09(\mathrm{~m}, 3 \mathrm{H}), 2.62-2.52(\mathrm{~m}$, $3 \mathrm{H}), 2.23-2.07(\mathrm{~m}, 3 \mathrm{H}), 1.81(\mathrm{dd}, J=12.0,5.0 \mathrm{~Hz}, 1 \mathrm{H}), 1.73-1.67$ (m, 2H), 1.55 (brs, $1 \mathrm{H}), 1.46(\mathrm{~s}, 3 \mathrm{H}), 1.45-1.40(\mathrm{~m}, 2 \mathrm{H}), 1.33-1.24(\mathrm{~m}, 3 \mathrm{H}), 1.04-0.97(\mathrm{~m}, 1 \mathrm{H}), 1.02(\mathrm{~s}$, $3 \mathrm{H}), 0.86(\mathrm{dq}, J=12.6,5.3 \mathrm{~Hz}, 1 \mathrm{H})$.

${ }^{13}$ C NMR (150 MHz, $\left.{ }_{6} \mathrm{D}_{6}\right): \delta 145.98(\mathrm{C}), 142.35(\mathrm{C}), 132.43(\mathrm{C}), 128.43(\mathrm{CH}), 128.17$ $(\mathrm{CH}), 125.93(\mathrm{CH}), 90.23(\mathrm{C}), 79.67(\mathrm{C}), 51.21(\mathrm{C}), 47.12(\mathrm{C}), 35.86\left(\mathrm{CH}_{2}\right), 33.47\left(\mathrm{CH}_{2}\right)$, $33.32\left(\mathrm{CH}_{2}\right), 28.05\left(\mathrm{CH}_{2}\right), 27.43\left(\mathrm{CH}_{2}\right), 27.16\left(\mathrm{CH}_{2}\right), 26.77\left(\mathrm{CH}_{3}\right), 18.65\left(\mathrm{CH}_{2}\right), 9.54$ $\left(\mathrm{CH}_{3}\right)$.

IR (neat, $\mathrm{cm}^{-1}$ ): 3404 (br), 2926 (s), 2857 (s), 1717 (w), 1651 (w), 1456 (m), 1080 (m), $1048(\mathrm{w}), 696(\mathrm{~m})$.

HRMS (ESI-TOF) (m/z): $[\mathrm{M}+\mathrm{H}]^{+}$calcd for $\mathrm{C}_{21} \mathrm{H}_{29} \mathrm{O}_{2}$ 313.2168; found, 313.2161. 
Structure Determination: The structure of 19 was determined by ${ }^{1} \mathrm{H}$ and ${ }^{13} \mathrm{C}$ NMR. The relative stereochemistry was assigned based on HSQC, HMBC, COSY, and NOESY analysis. $^{7}$
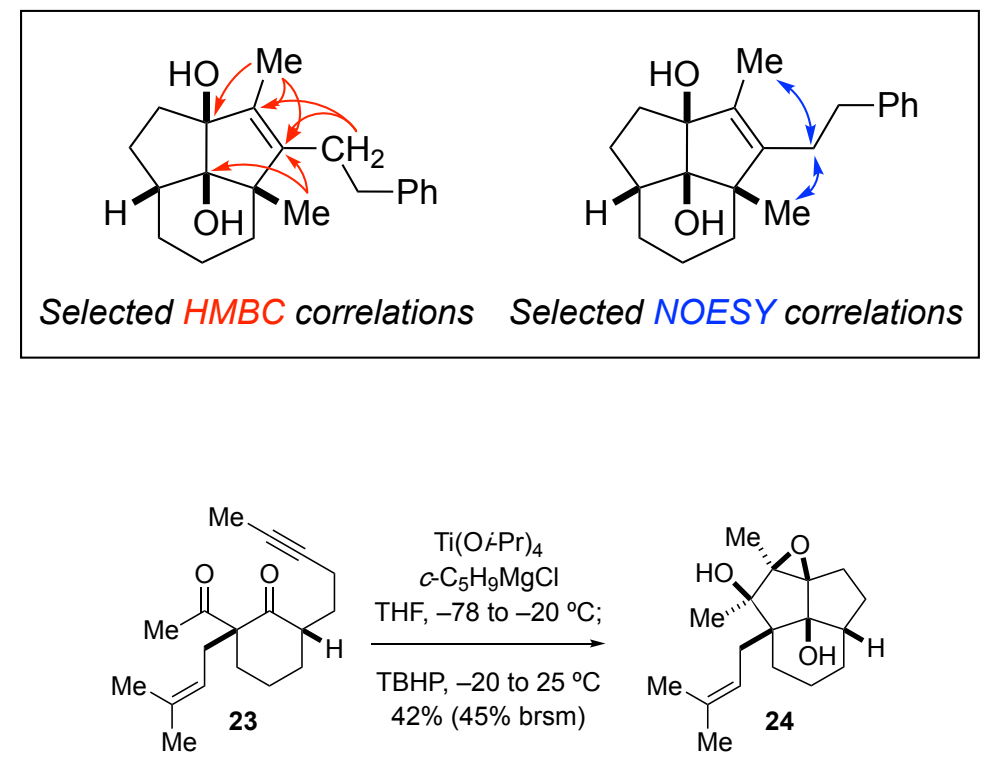

\section{Preparation of 24:}

To a stirred solution of $\mathrm{Ti}(\mathrm{O} i-\mathrm{Pr})_{4}(63 \mu \mathrm{L}, 0.210 \mathrm{mmol}, 2.1$ equiv $)$ in $2 \mathrm{~mL}$ dry THF at $-78{ }^{\circ} \mathrm{C}$ was dropwise added cyclopentylmagnesium chloride $(283 \mu \mathrm{L}, 0.494$ mmol, $1.49 \mathrm{M}$ in $\mathrm{Et}_{2} \mathrm{O}, 4.2$ equiv). After $30 \mathrm{~min}$, a solution of 23 (27.5 mg, $0.1 \mathrm{mmol}, 1.0$ equiv) in $5 \mathrm{~mL}$ dry THF (additional $2 \mathrm{~mL}$ wash) was added dropwise and the reaction mixture was warmed to $-20{ }^{\circ} \mathrm{C}$. After $2 \mathrm{~h}$, TBHP $(200 \mu \mathrm{L}, 1.0 \mathrm{mmol}, 5.5 \mathrm{M}$ in nonane, 10 equiv) was added and the mixture was stirred for $2 \mathrm{~h}$ at room temperature. The reaction was quenched with a half-saturated aq. $\mathrm{NaHCO}_{3}$ solution and stirred overnight. The biphasic mixture was filtered through a plug of celite. The layers were separated and the aqueous phase was extracted with $2 \mathrm{~mL}$ ethyl acetate (x 2). The combined organic phase was washed with brine, dried over anhydrous $\mathrm{MgSO}_{4}$, filtered, and concentrated under reduced pressure. The crude was purified on Biotage 10G SNAP Ultra to afford $12.3 \mathrm{mg} 24$ (42\% yield) as white solid along with $1.7 \mathrm{mg}$ unreacted 23.

\section{Analytical data for compound 24:}

TLC: $\mathrm{R}_{\mathrm{f}}=0.42(33 \%$ EtOAc in hexanes $)$.

${ }^{1}$ H NMR $\left(600 \mathrm{MHz}, \mathrm{CDCl}_{3}\right): \delta 5.27-5.24(\mathrm{~m}, 1 \mathrm{H}), 2.64(\mathrm{~s}, 1 \mathrm{H}), 2.55(\mathrm{dd}, J=14.9,8.3$ $\mathrm{Hz}, 1 \mathrm{H}), 2.35-2.29(\mathrm{~m}, 1 \mathrm{H}), 2.11-2.06(\mathrm{~m}, 4 \mathrm{H}), 1.82-1.78(\mathrm{~m}, 1 \mathrm{H}), 1.77-1.72(\mathrm{~m}$, $2 \mathrm{H}), 1.70(\mathrm{~s}, 3 \mathrm{H}), 1.52-1.48(\mathrm{~m}, 1 \mathrm{H}), 1.47-1.38(\mathrm{~m}, 2 \mathrm{H}), 1.37(\mathrm{~s}, 3 \mathrm{H}), 1.16(\mathrm{~s}, 3 \mathrm{H})$, $1.11-1.04(\mathrm{~m}, 1 \mathrm{H}), 0.75-0.69(\mathrm{~m}, 1 \mathrm{H})$. 
${ }^{13}$ C NMR (150 MHz, $\left.\mathrm{CDCl}_{3}\right): \delta 132.56(\mathrm{C}), 121.57(\mathrm{CH}), 85.21(\mathrm{C}), 84.14(\mathrm{C}), 83.48$ (C), $73.88(\mathrm{C}), 55.64(\mathrm{C}), 43.50(\mathrm{CH}), 31.57\left(\mathrm{CH}_{2}\right), 29.89\left(\mathrm{CH}_{2}\right), 27.30\left(\mathrm{CH}_{2}\right), 26.35$ $\left(\mathrm{CH}_{2}\right), 26.21\left(\mathrm{CH}_{3}\right), 23.30\left(\mathrm{CH}_{2}\right), 20.48\left(\mathrm{CH}_{3}\right), 18.82\left(\mathrm{CH}_{2}\right), 17.92\left(\mathrm{CH}_{3}\right), 14.15\left(\mathrm{CH}_{3}\right)$.

IR (neat, $\mathrm{cm}^{-1}$ ): 3446 (br), 2931 (s), 2864 (s), 1717 (w), 1699 (w), 1653 (w), 1558 (w), $1457(\mathrm{~m}), 1036(\mathrm{~m})$.

HRMS (ESI-TOF) (m/z): [M + H] calcd for $\mathrm{C}_{18} \mathrm{H}_{29} \mathrm{O}_{3}$ 293.2117; found, 293.2121.

Structure Determination: The structure of 24 was determined by ${ }^{1} \mathrm{H}$ and ${ }^{13} \mathrm{C} N M R$. The relative stereochemistry was assigned based on HSQC, HMBC, COSY, and NOESY analysis. The structure was further confirmed by X-ray crystallography. ${ }^{7}$

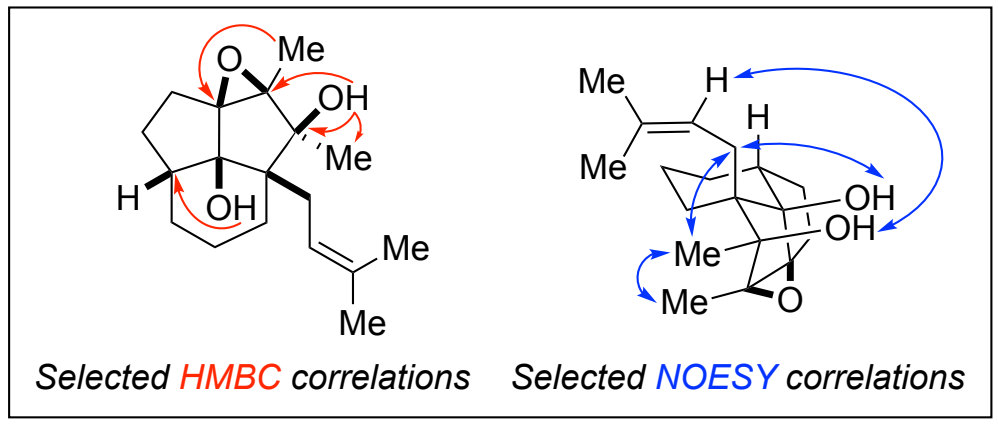

(5) Construction of 7-5-5 Fused Tricycles - Synthesis of $21 \& 22$
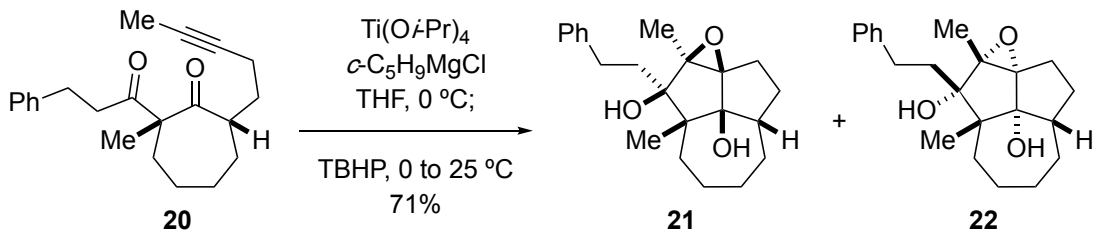

To a stirred solution of $\mathbf{2 0}$ (131.0 $\mathrm{mg}, 0.404 \mathrm{mmol}, 1.0$ equiv) in $15 \mathrm{~mL}$ dry THF was added $\mathrm{Ti}(\mathrm{O} i \text { - } \mathrm{Pr})_{4}\left(252 \mu \mathrm{L}, 0.848 \mathrm{mmol}, 2.1\right.$ equiv) at $0{ }^{\circ} \mathrm{C}$. Cyclopentylmagnesium chloride $\left(945 \mu \mathrm{L}, 1.697 \mathrm{mmol}, 1.80 \mathrm{M}^{\text {in }} \mathrm{Et}_{2} \mathrm{O}, 4.2\right.$ equiv) was added dropwise. After complete consumption of starting material (10 min), TBHP $(800 \mu \mathrm{L}, \sim 4.04 \mathrm{mmol}, 5-6 \mathrm{M}$ in decane, $\sim 10$ equiv) was added and the reaction mixture was warmed up to room temperature. After $1.5 \mathrm{~h}$, the reaction is quenched with a half-saturated aq. $\mathrm{NaHCO}_{3}$ solution and stirred for an additional $1 \mathrm{~h}$. The biphasic mixture was filtered through a plug of celite. The layers were separated and the aqueous phase was extracted with $2 \mathrm{~mL}$ ethyl acetate (x 2). The combined organic phase was washed with brine, dried over anhydrous $\mathrm{MgSO}_{4}$, filtered, and concentrated under reduced pressure. The crude was purified on Biotage 10G SNAP Ultra to afford $54 \mathrm{mg} 21$ (white solid, 39\% yield) and 44 mg 22 (white solid, 32\% yield). 


\section{Analytical data for compound 21:}

TLC: $\mathrm{R}_{\mathrm{f}}=0.15(20 \%$ EtOAc in hexanes $)$.

${ }^{1}$ H NMR $\left(600 \mathrm{MHz}, \mathrm{CDCl}_{3}\right): \delta$ 7.30-7.28 (m, 2H), 7.21-7.18 (m, 3H), $3.08(\mathrm{~s}, 1 \mathrm{H})$, 2.84-2.78 (m , 1H), 2.74-2.69 (m , 1H), $2.53(\mathrm{~s}, 1 \mathrm{H}), 2.30-2.26(\mathrm{~m}, 1 \mathrm{H}), 2.05-1.94(\mathrm{~m}$, $2 \mathrm{H}), 1.89-1.58(\mathrm{~m}, 10 \mathrm{H}), 1.49(\mathrm{~s}, 3 \mathrm{H}), 1.49-1.46(\mathrm{~m}, 1 \mathrm{H}), 1.30-1.25(\mathrm{~m}, 1 \mathrm{H}), 1.12(\mathrm{~s}$, $3 \mathrm{H})$.

${ }^{13}$ C NMR (150 MHz, $\left.\mathrm{CDCl}_{3}\right): \delta 142.85(\mathrm{C}), 128.48(\mathrm{CH}), 128.29(\mathrm{CH}), 125.87(\mathrm{CH})$, $85.57(\mathrm{C}), 82.43(\mathrm{C}), 82.32(\mathrm{C}), 74.39(\mathrm{C}), 62.88(\mathrm{C}), 51.28(\mathrm{CH}), 36.20\left(\mathrm{CH}_{2}\right), 30.53$ $\left(\mathrm{CH}_{2}\right), 30.17\left(\mathrm{CH}_{2}\right), 25.96\left(\mathrm{CH}_{2}\right), 25.78\left(\mathrm{CH}_{2}\right), 24.79\left(\mathrm{CH}_{2}\right), 23.67\left(\mathrm{CH}_{2}\right), 23.47\left(\mathrm{CH}_{2}\right)$, $15.23\left(\mathrm{CH}_{3}\right), 14.23\left(\mathrm{CH}_{3}\right)$.

IR (neat, $\mathrm{cm}^{-1}$ ): 3446 (br), 3025 (w), 2940 (s), 2868 (s), 1603 (w), 1496 (w), 1456 (m), $1379(\mathrm{~m} 0,1111(\mathrm{~m} 0,1041(\mathrm{~m}), 736(\mathrm{~s}), 700(\mathrm{~s})$.

HRMS (ESI-TOF) (m/z): $[\mathrm{M}+\mathrm{Na}]^{+}$calcd for $\mathrm{C}_{22} \mathrm{H}_{30} \mathrm{O}_{3} \mathrm{Na}$ 365.2093; found, 365.2088.

Structure Determination: The structure of 21 was determined by ${ }^{1} \mathrm{H}$ and ${ }^{13} \mathrm{C} N M R$. The connectivity of the atoms was assigned based on HSQC and HMBC analysis. The structure was confirmed by single-crystal X-ray analysis. ${ }^{7}$

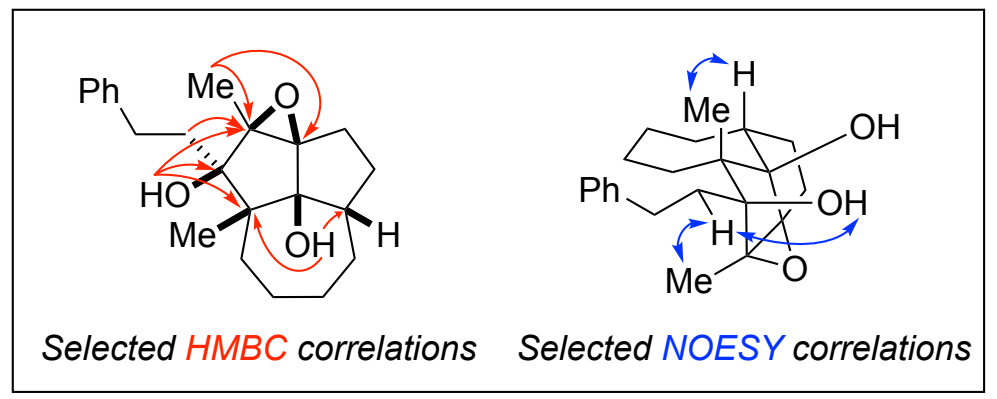

\section{Analytical data for compound 22:}

TLC: $R_{\mathrm{f}}=0.36(20 \%$ EtOAc in hexanes $)$.

${ }^{1} \mathbf{H}$ NMR (600 MHz, $\left.\mathrm{CDCl}_{3}\right): \delta 7.30-7.28(\mathrm{~m}, 2 \mathrm{H}), 7.22-7.18(\mathrm{~m}, 3 \mathrm{H}), 3.21(\mathrm{~s}, \mathrm{H}), 2.77$ $(\mathrm{m}, 2 \mathrm{H}), 2.46$ (s, 1H), 2.13-2.04 (m, 2H), 1.96-1.89 (m, 3H), 1.88-1.80 (m, 3H), 1.79$1.74(\mathrm{~m}, 2 \mathrm{H}), 1.68-1.61(\mathrm{~m}, 2 \mathrm{H}), 1.59-1.46(\mathrm{~m}, 2 \mathrm{H}), 1.42(\mathrm{~s}, 3 \mathrm{H}), 1.28-1.24(\mathrm{~m}, 1 \mathrm{H})$, $1.01(\mathrm{~s}, 3 \mathrm{H})$.

${ }^{13}$ C NMR (150 MHz, $\left.\mathrm{CDCl}_{3}\right): \delta 142.97(\mathrm{C}), 128.45(\mathrm{CH}), 128.34(\mathrm{CH}), 125.81(\mathrm{CH})$, 88.14 (C), 85.22 (C), 82.93 (C), $73.51(\mathrm{C}), 56.67(\mathrm{C}), 42.14(\mathrm{CH}), 37.47\left(\mathrm{CH}_{2}\right), 32.77$ 
$\left(\mathrm{CH}_{2}\right), 30.37\left(\mathrm{CH}_{2}\right), 29.41\left(\mathrm{CH}_{2}\right), 27.42\left(\mathrm{CH}_{2}\right), 26.82\left(\mathrm{CH}_{2}\right), 26.10\left(\mathrm{CH}_{2}\right), 25.22\left(\mathrm{CH}_{2}\right)$, $23.56\left(\mathrm{CH}_{3}\right), 15.15\left(\mathrm{CH}_{3}\right)$.

IR (neat, $\mathrm{cm}^{-1}$ ): 3446 (br), 3060 (w), 3026 (m), 2958 (s), 2927 (s), 2857 (s), 1699 (w), $1602(\mathrm{~m}), 1469(\mathrm{~m}), 1456(\mathrm{~s}), 1380(\mathrm{~m}), 1265(\mathrm{w}), 1123(\mathrm{~m}), 1030(\mathrm{w}), 1001(\mathrm{w}), 886$ (m), $738(\mathrm{~s})$.

HRMS (ESI-TOF) (m/z): [M + Na] $]^{+}$calcd for $\mathrm{C}_{22} \mathrm{H}_{30} \mathrm{O}_{3} \mathrm{Na}$ 365.2093; found, 365.2087.

Structure Determination: The structure of 22 was determined by ${ }^{1} \mathrm{H}$ and ${ }^{13} \mathrm{C}$ NMR. The connectivity of the atoms was assigned based on HSQC and HMBC analysis. The structure was confirmed by single-crystal X-ray analysis. ${ }^{7}$

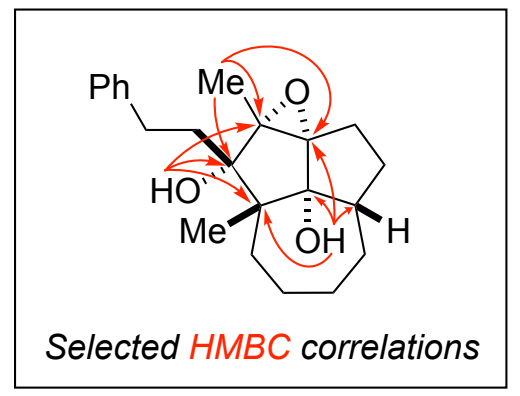

\footnotetext{
${ }^{1}$ Burchat, A. F.; Chong, J. M.; Nielsen, N. J. Organomet. Chem. 1997, 542, 281-283.

${ }^{2}$ Love, B. E.; Jones, E. G. J. Org. Chem. 1999, 64, 3755-3756.

${ }^{3}$ Kamijo, S.; Dudley, G. B. J. Am. Chem. Soc. 2005, 127, 5028-5029.

${ }^{4}$ Brandt, D.; Bellosta, V.; Cossy, J. Org. Lett. 2012, 14, 5594-5597.

${ }^{5}$ Davidson, J. P.; Corey, E. J. J. Am. Chem. Soc. 2003, 125, 13486-13489.

${ }^{6}$ Kier, M. J.; Leon, R. M.; O’Rourke, N. F.; Rheingold, A. L.; Micalizio, G. C. J. Am. Chem. Soc. 2017, 139, 12374-12377.

${ }^{7}$ The stereochemistry depicted here is relative. The compound was made as a racemic mixture.

${ }^{8}$ Clift, M. D.; Taylor, C. N.; Thomson, R. J. Org. Lett. 2007, 9, 4667-4669.

${ }^{9}$ Clift, M. D.; Thomson, R. J. J. Am. Chem. Soc. 2009, 131, 14579-14583.
} 


\section{NMR Spectra of New Compounds}

${ }^{1} \mathrm{H}$ and ${ }^{13} \mathrm{C}$ NMR spectra of all the new compounds (substrates and annulation products) are given below. For spectra of compounds 10 and 11, see ref. 6 . 

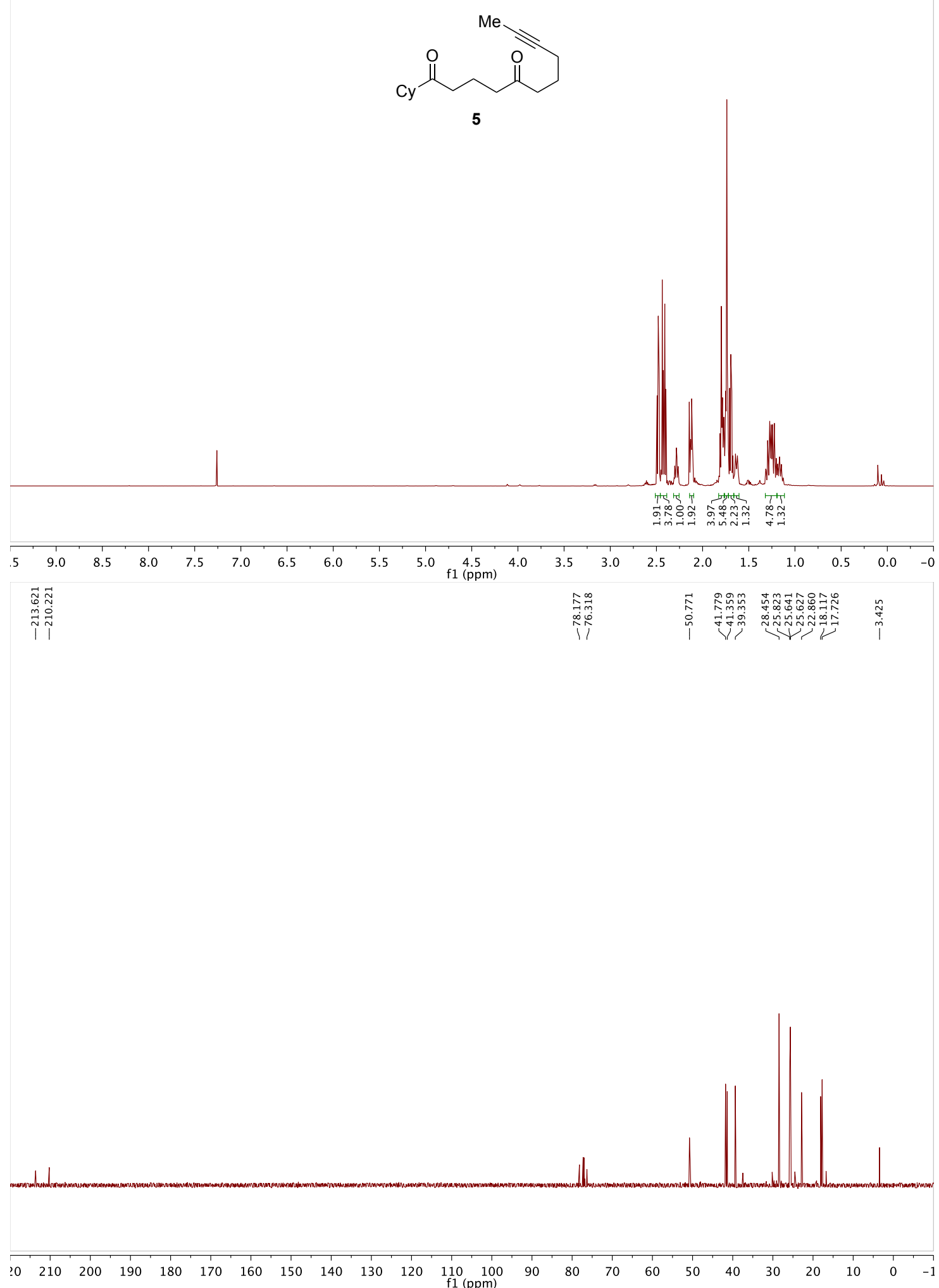
<smiles>CC#CCCC1CCCCC1=O</smiles>

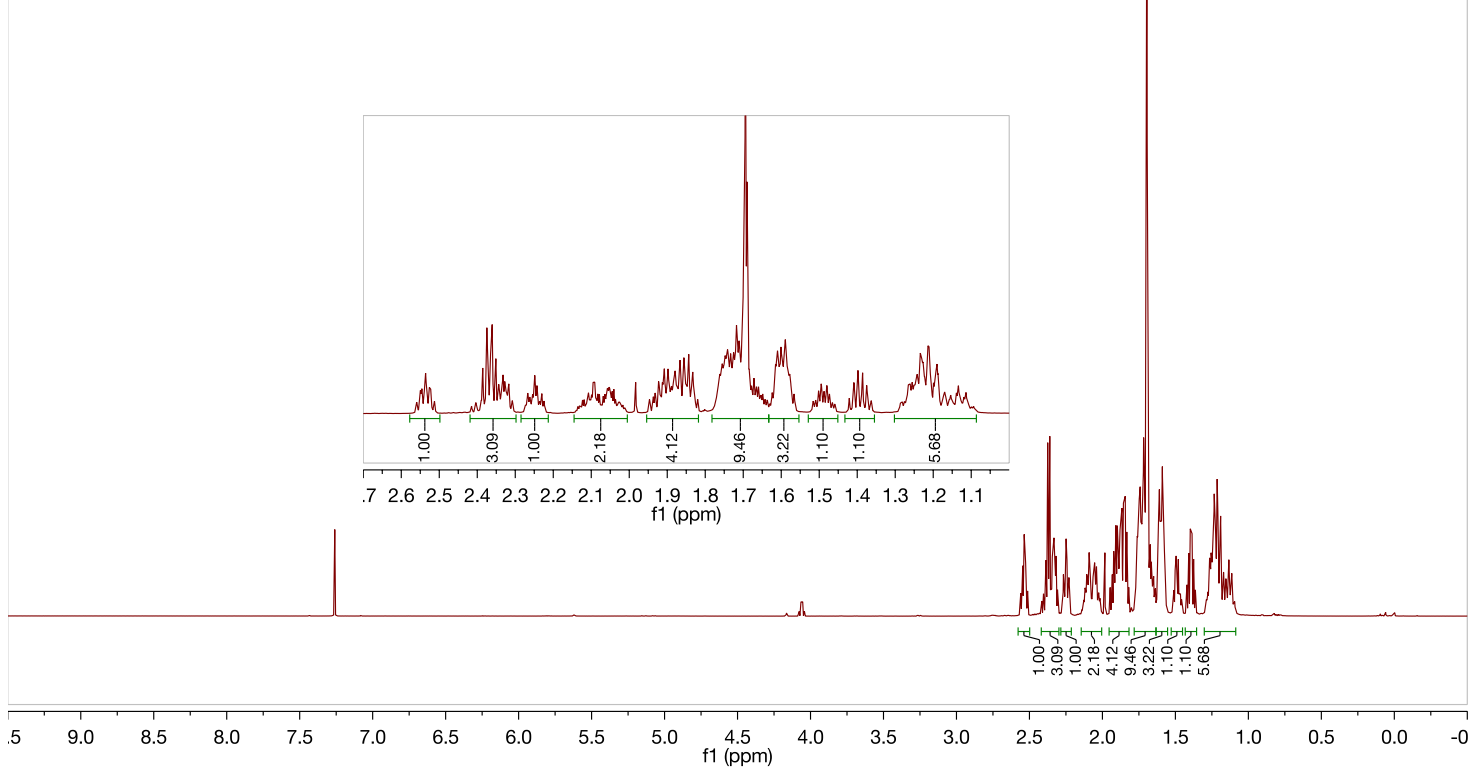

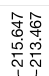

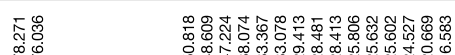

11
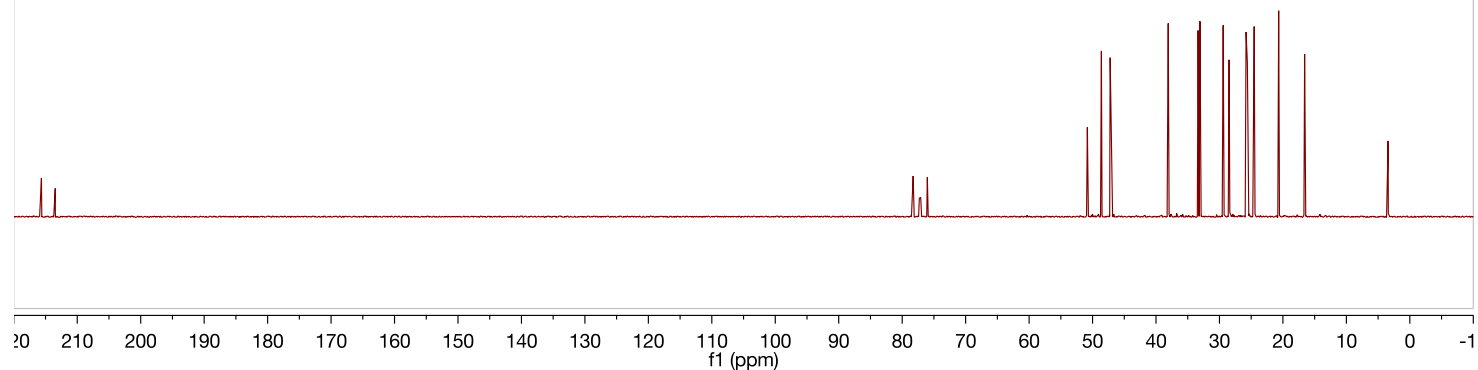
<smiles>CC#CCCC1CCCCC1CC(=O)C(C)C</smiles>

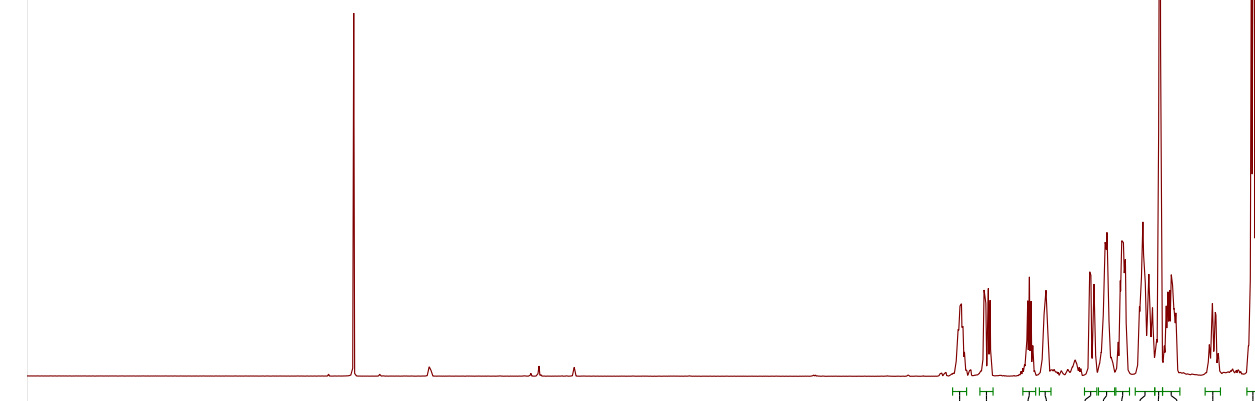

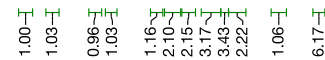
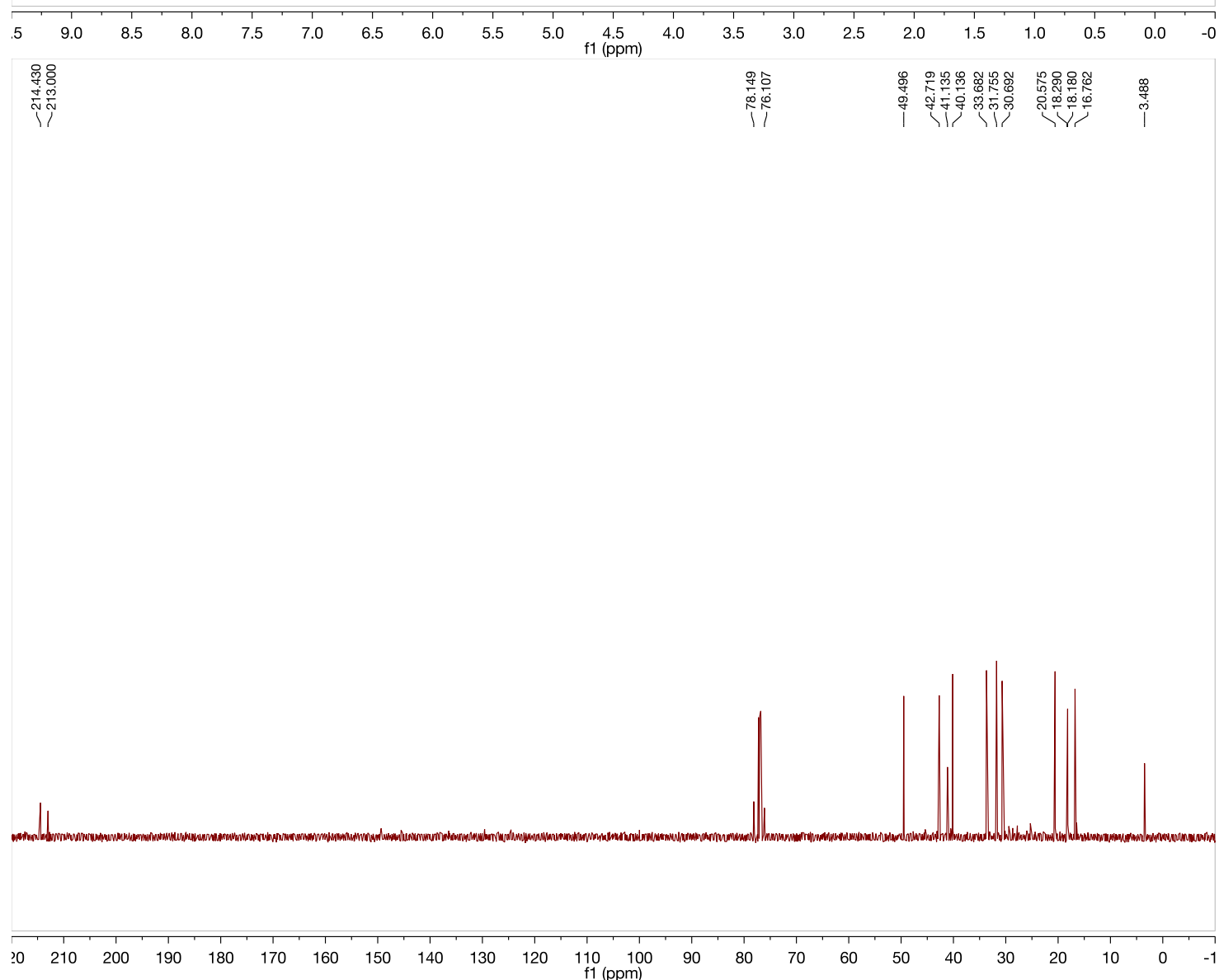


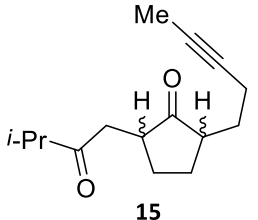

(mixture of diastereomers)
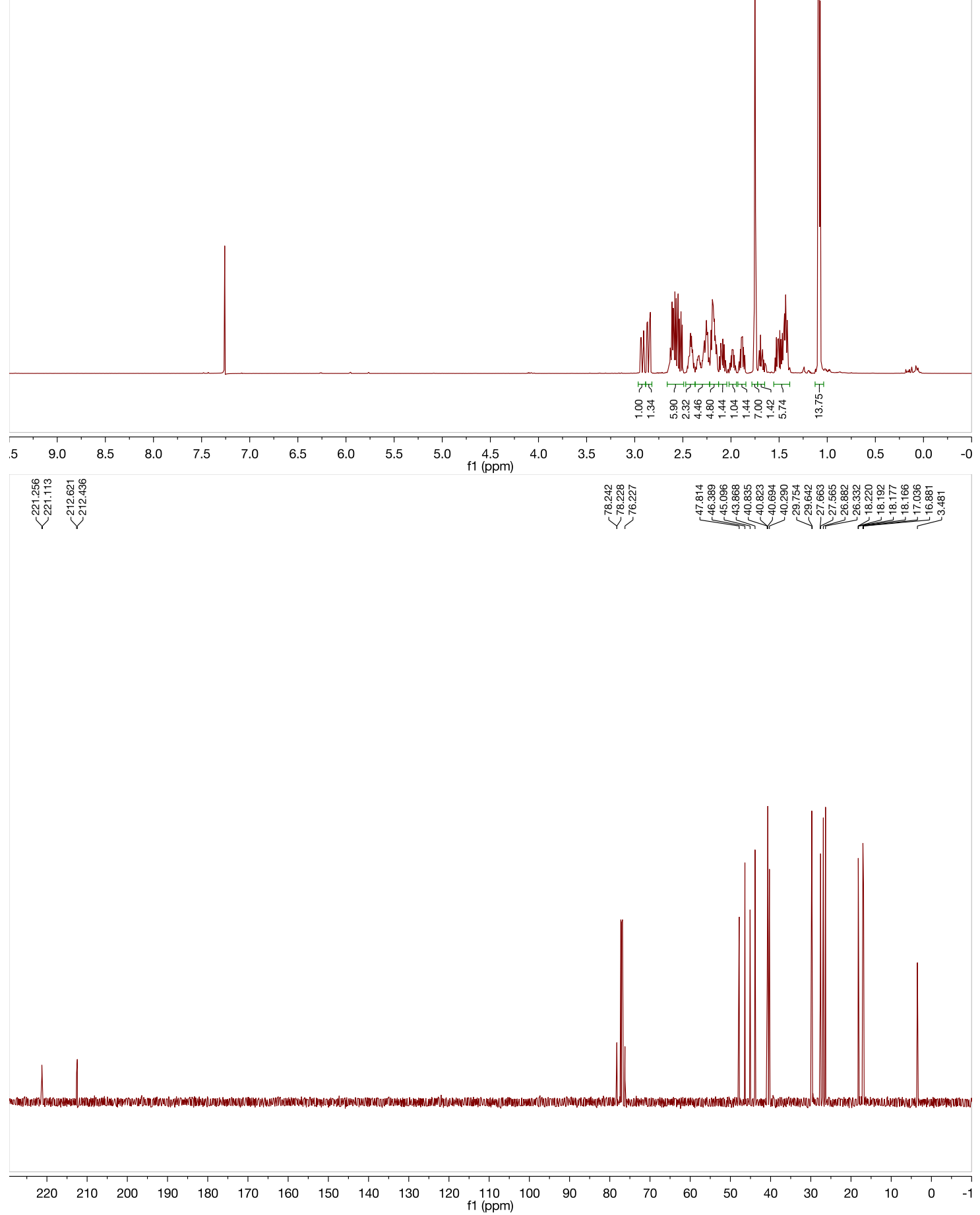

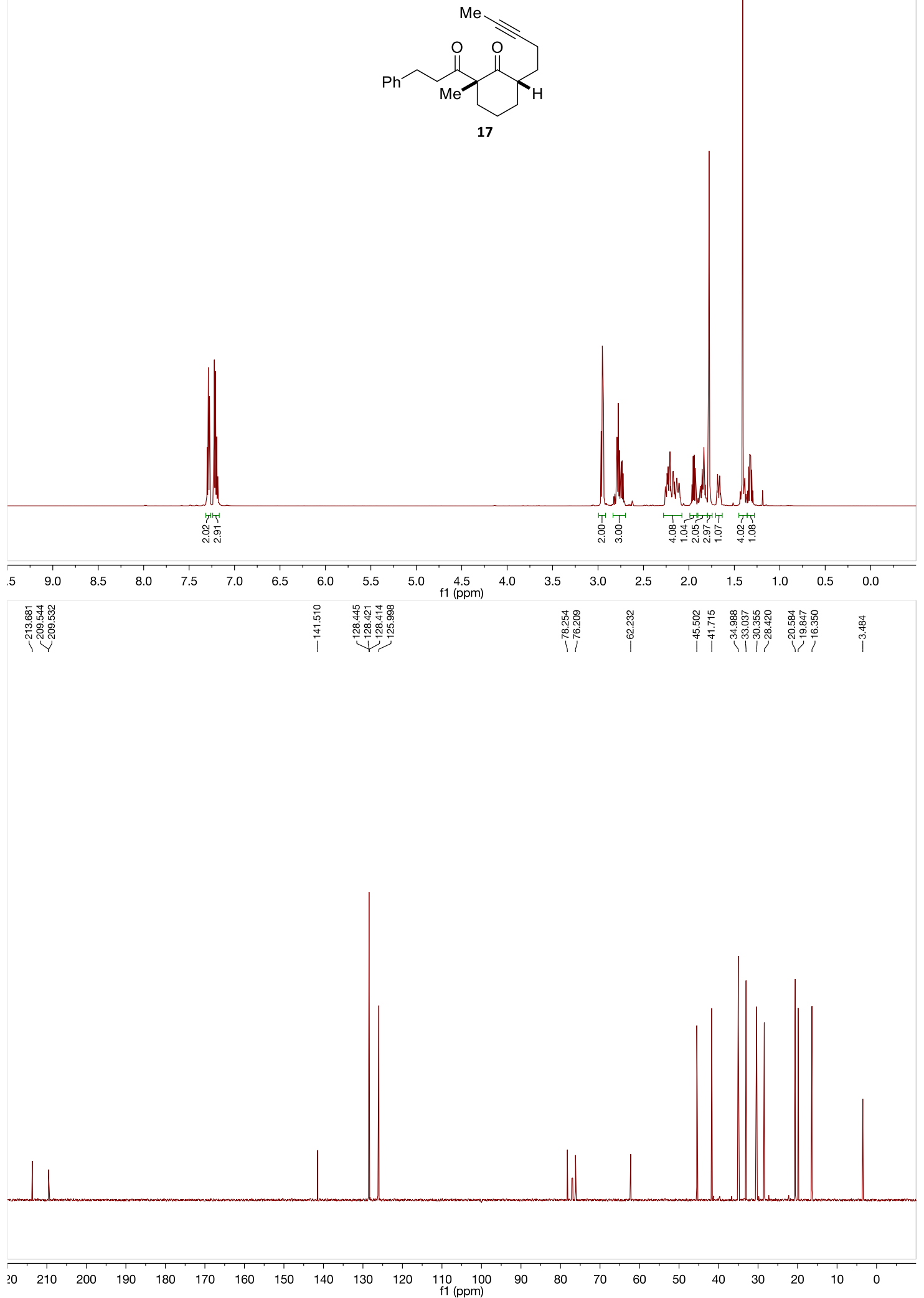

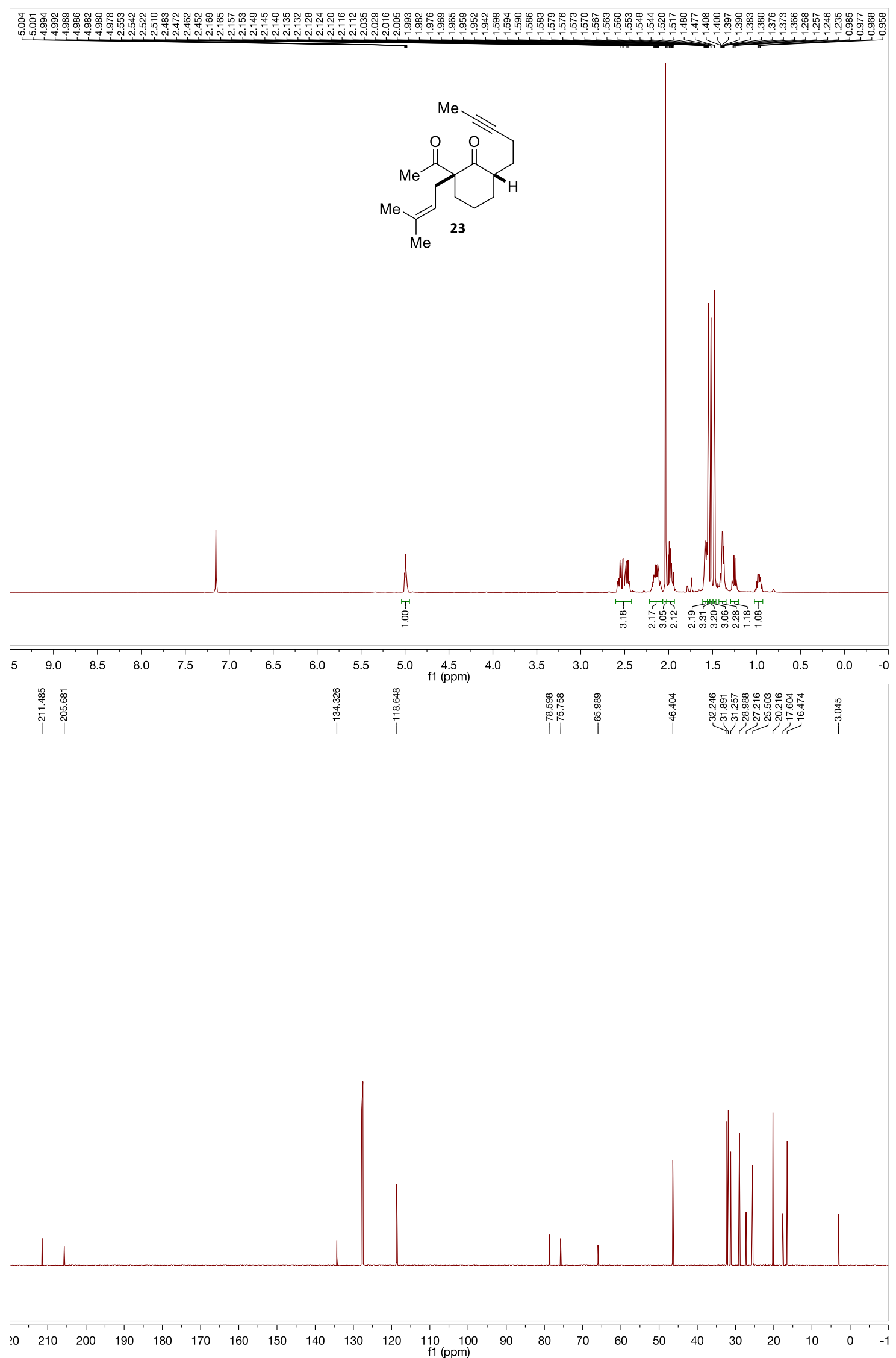

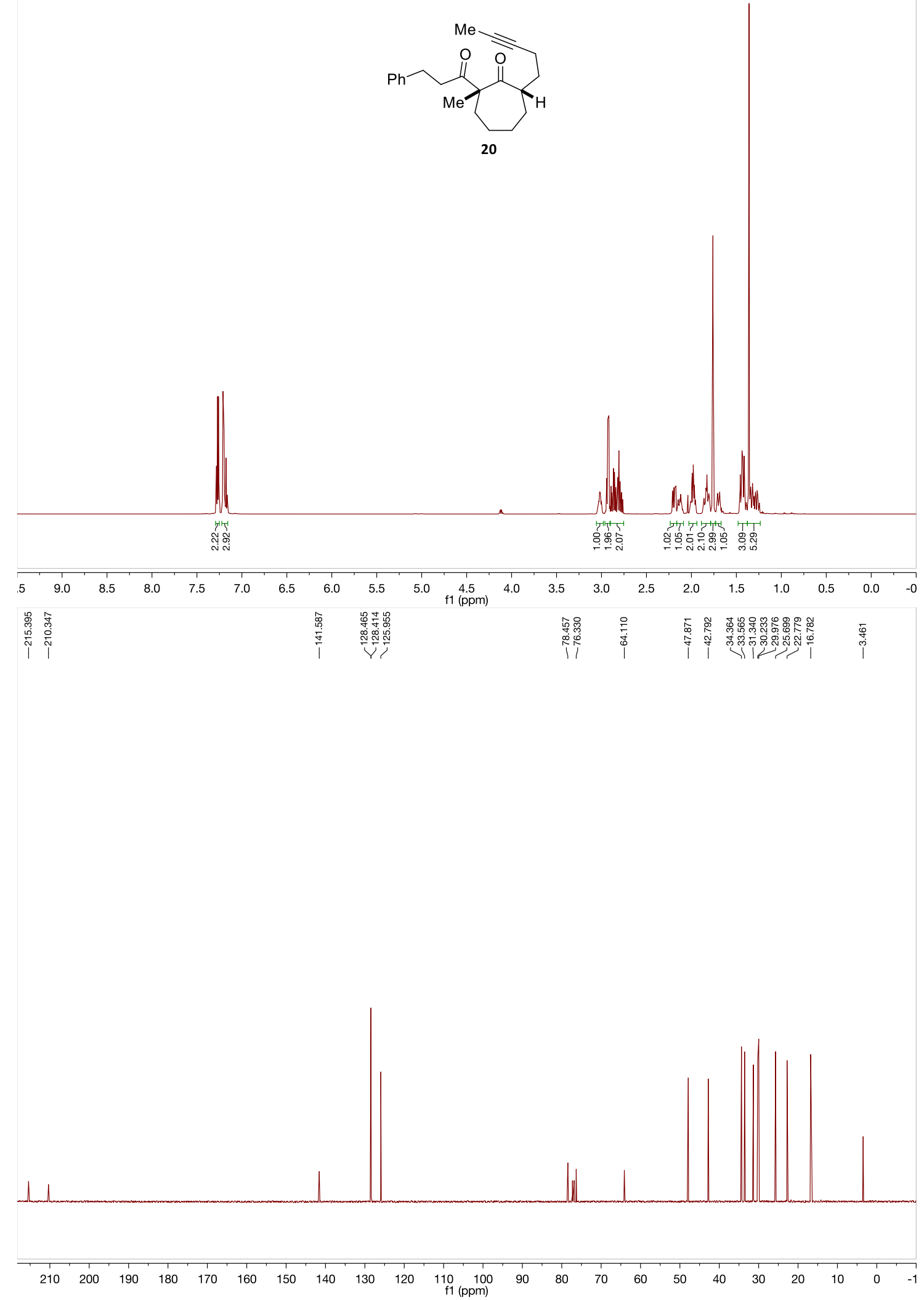

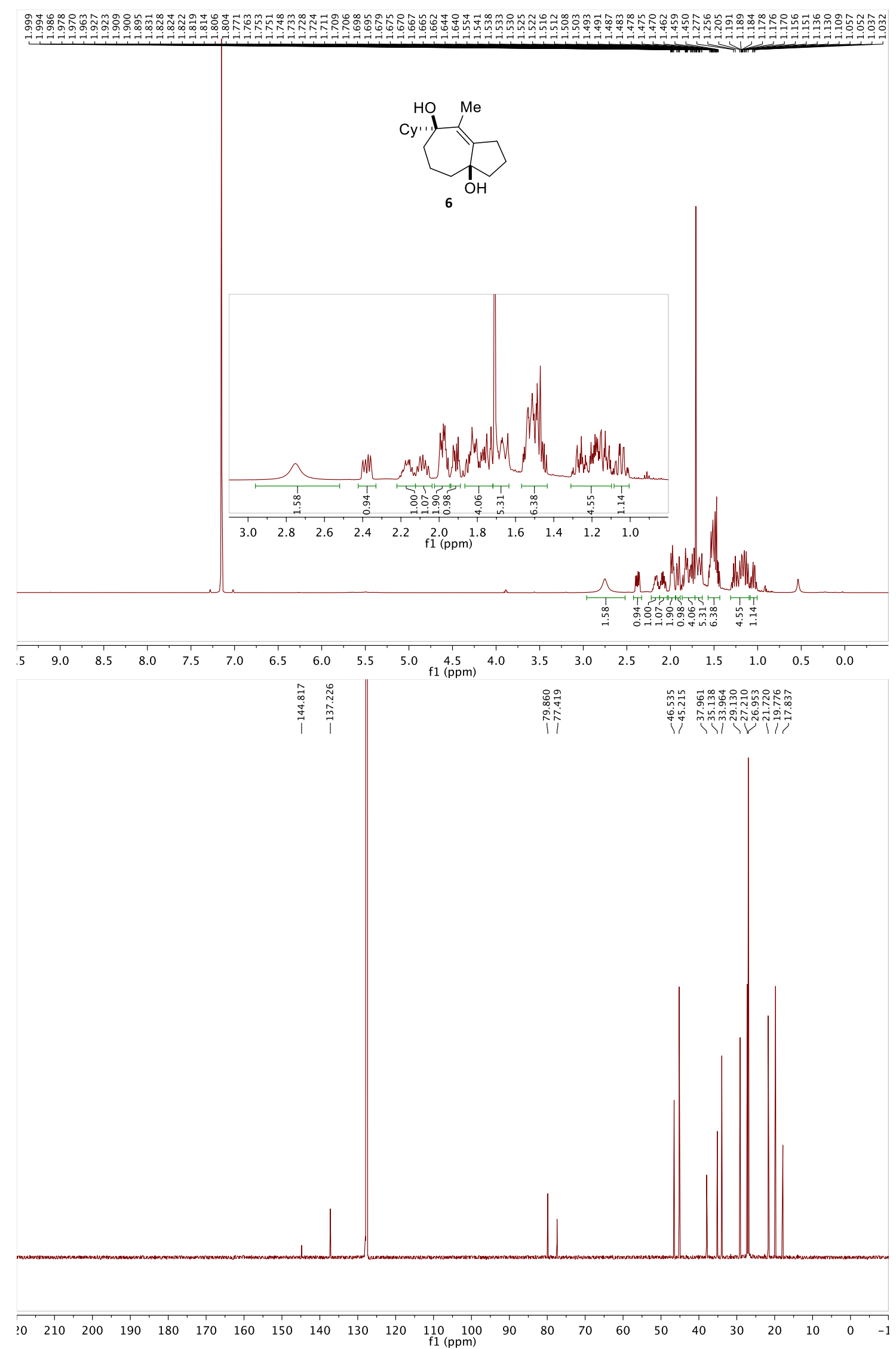

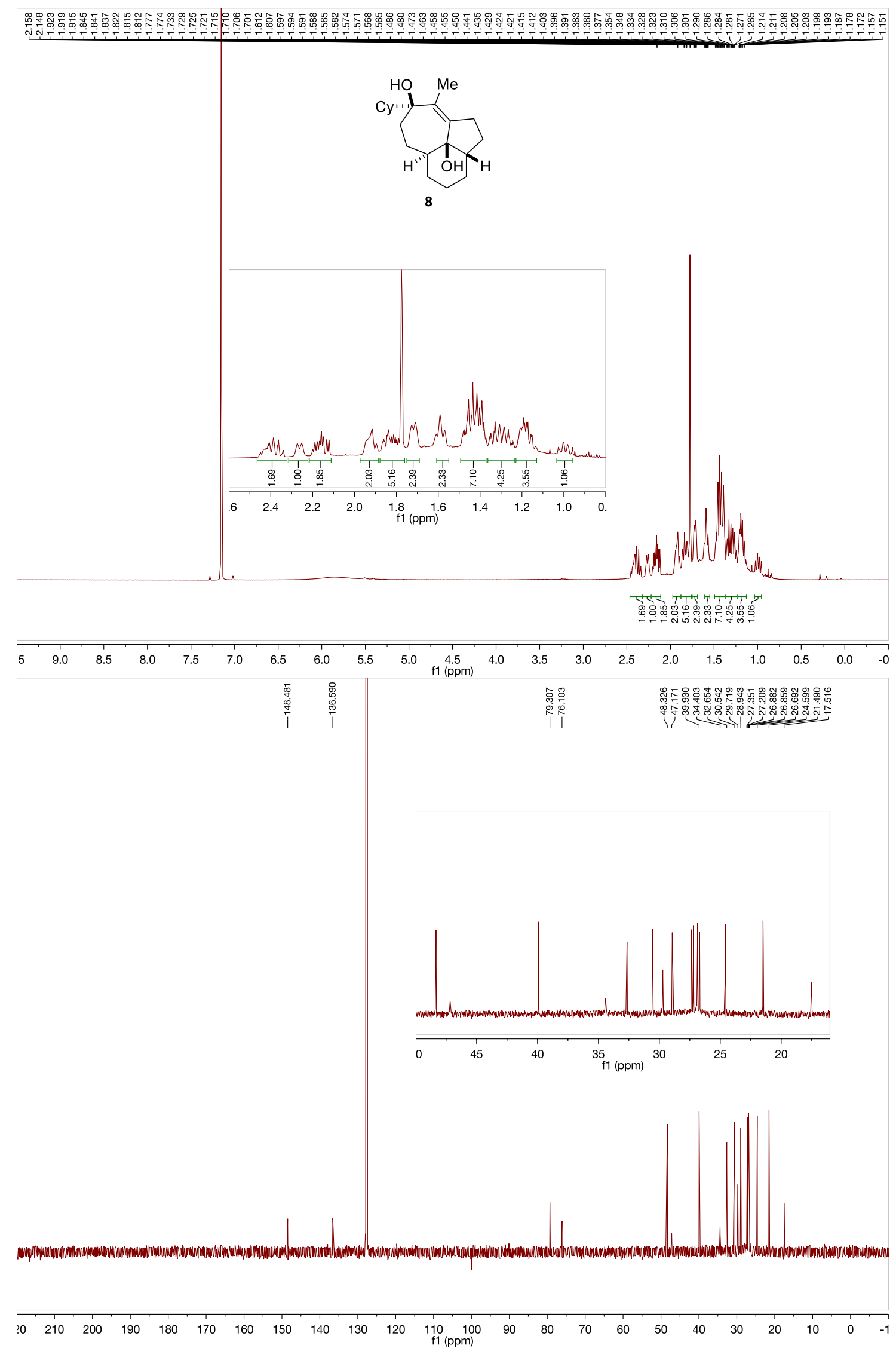

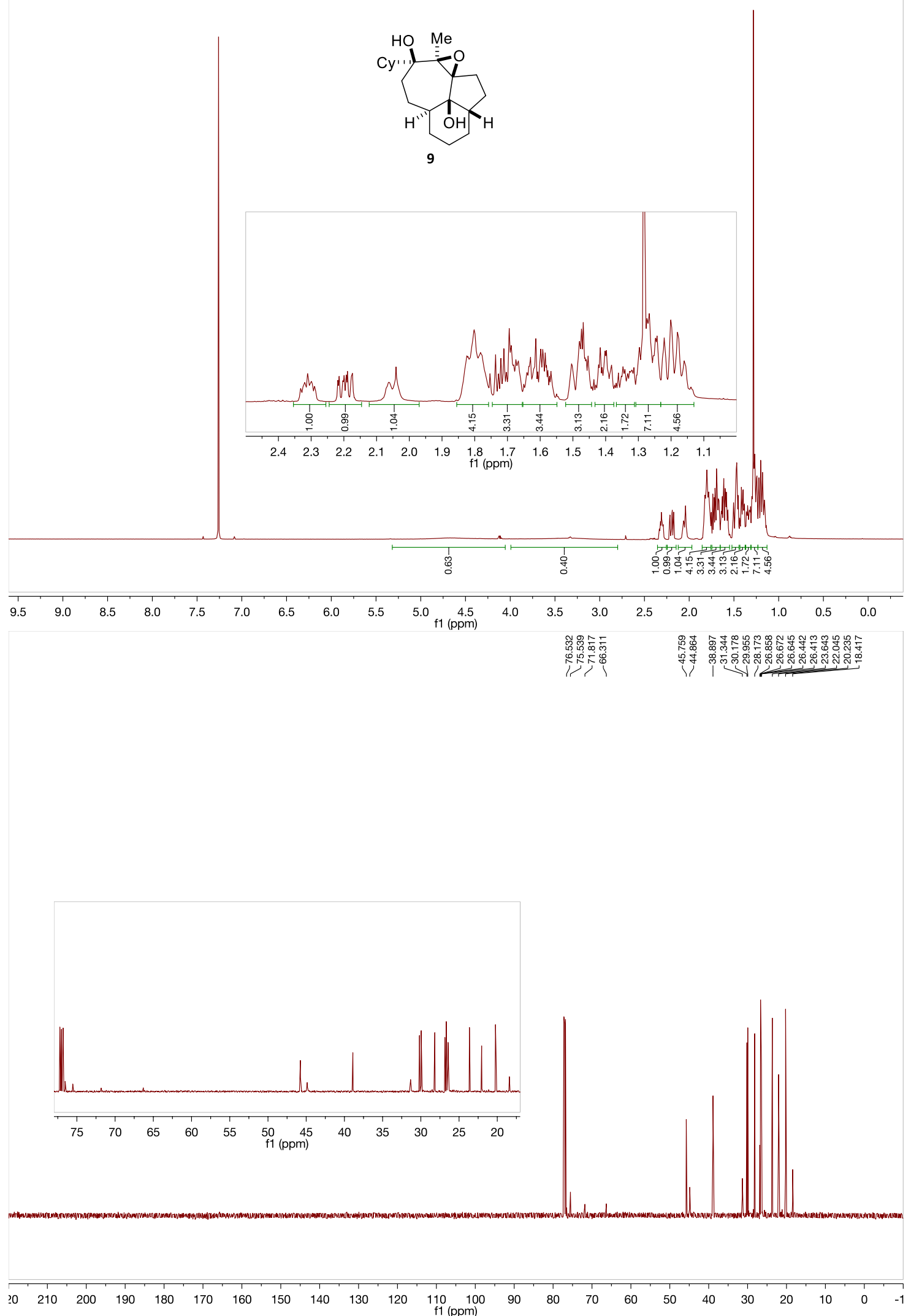


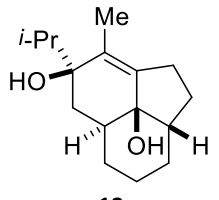

13
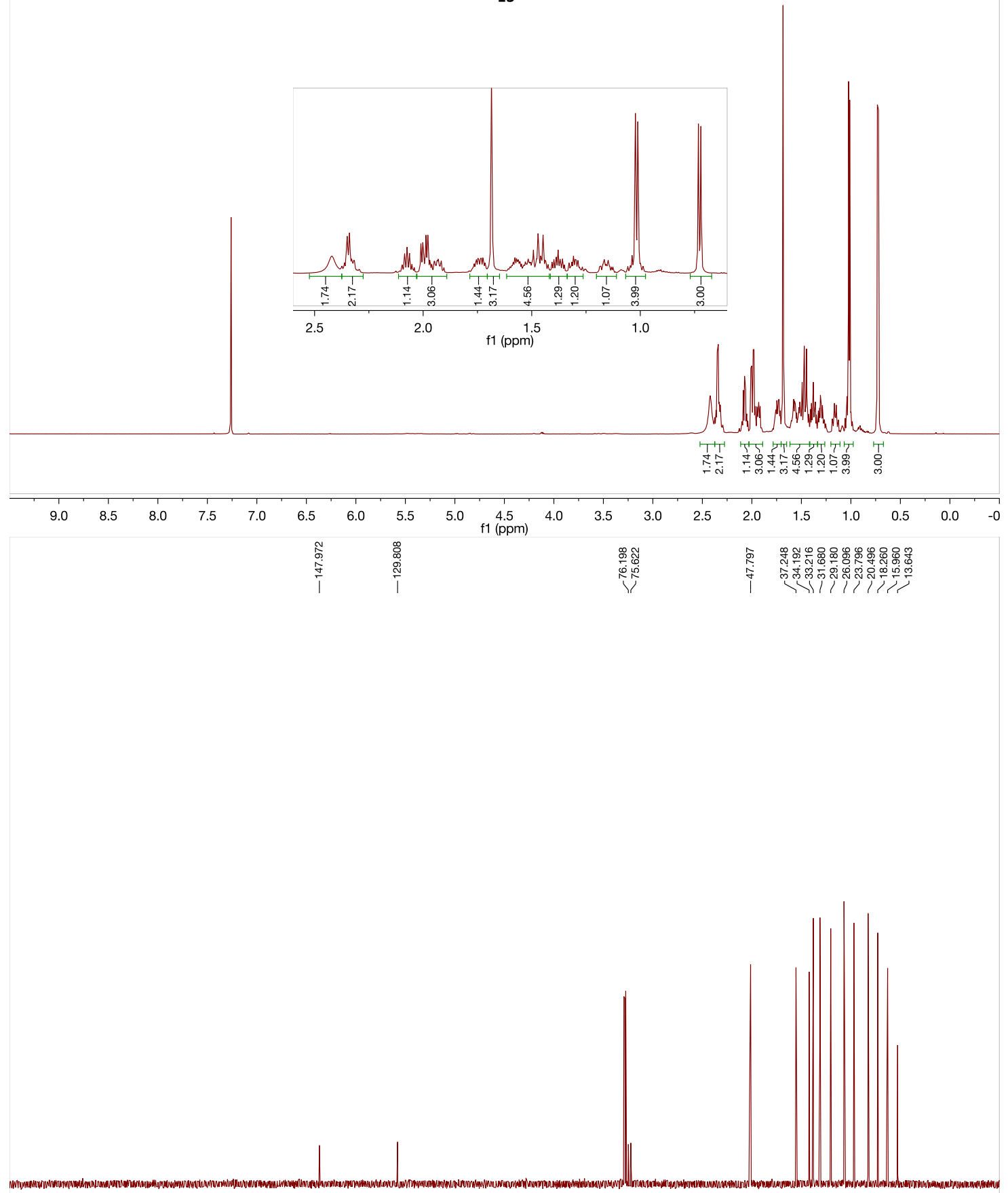

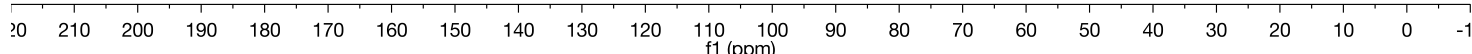



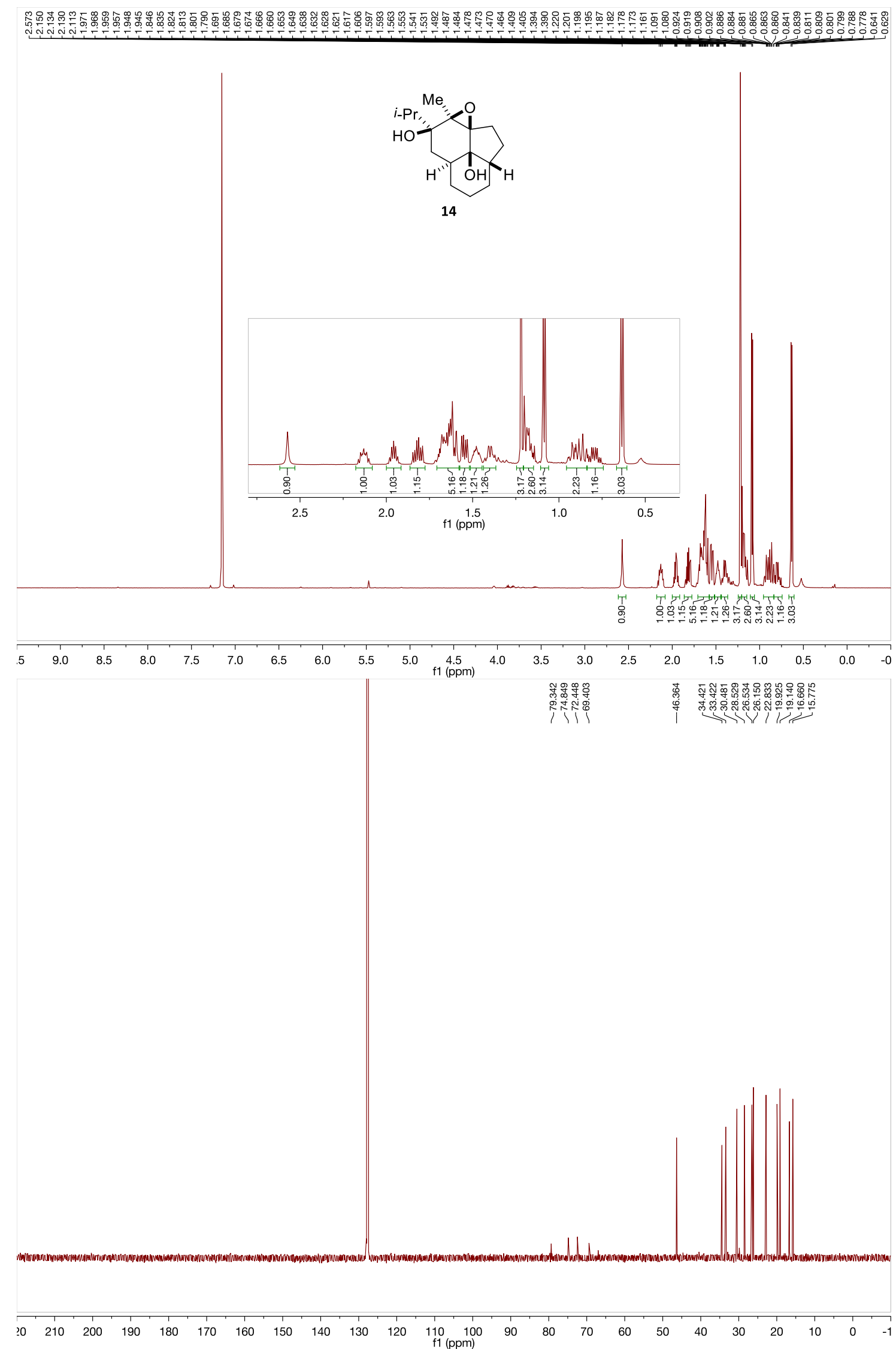

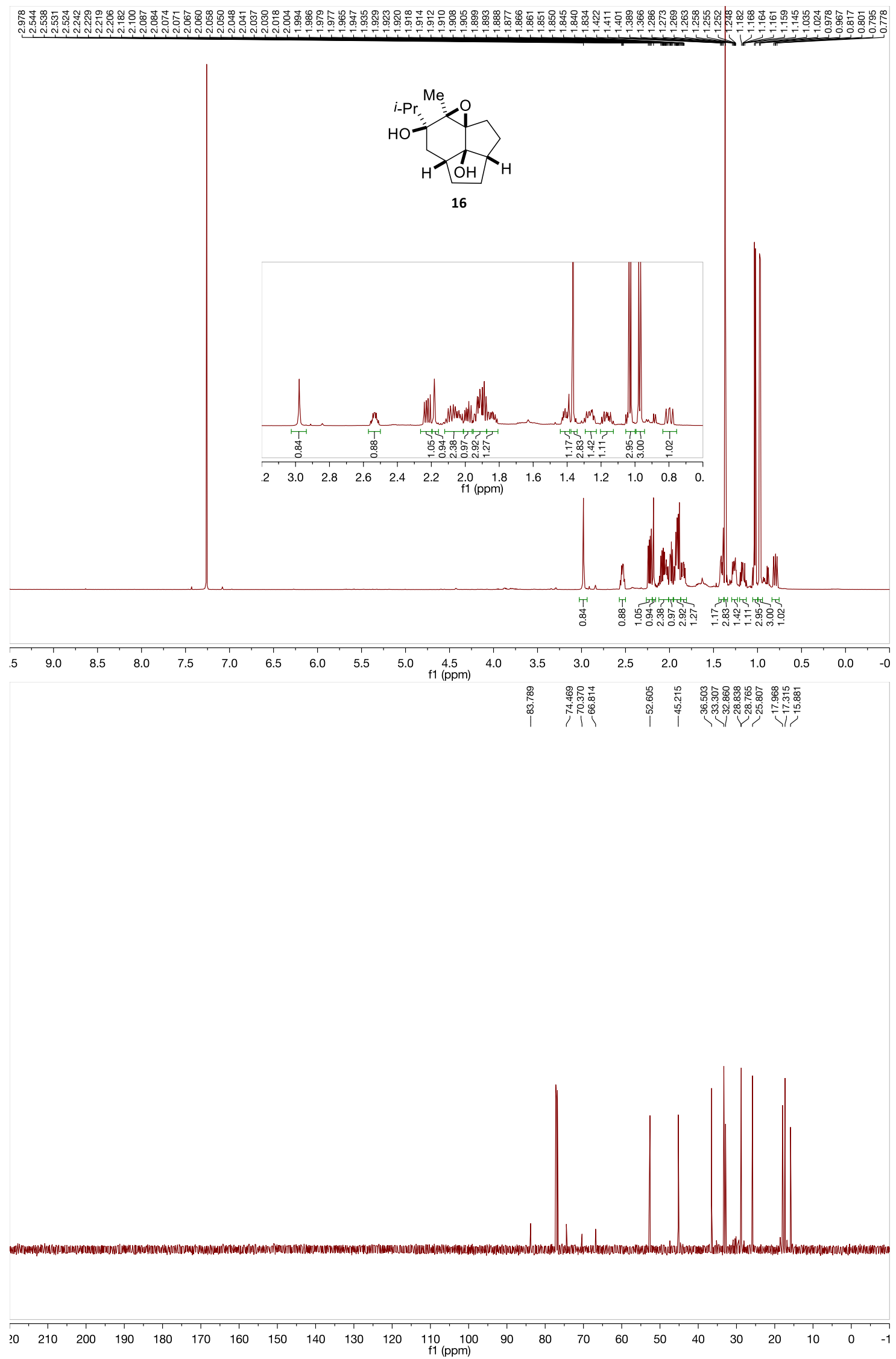


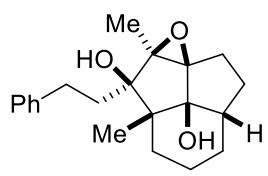

18

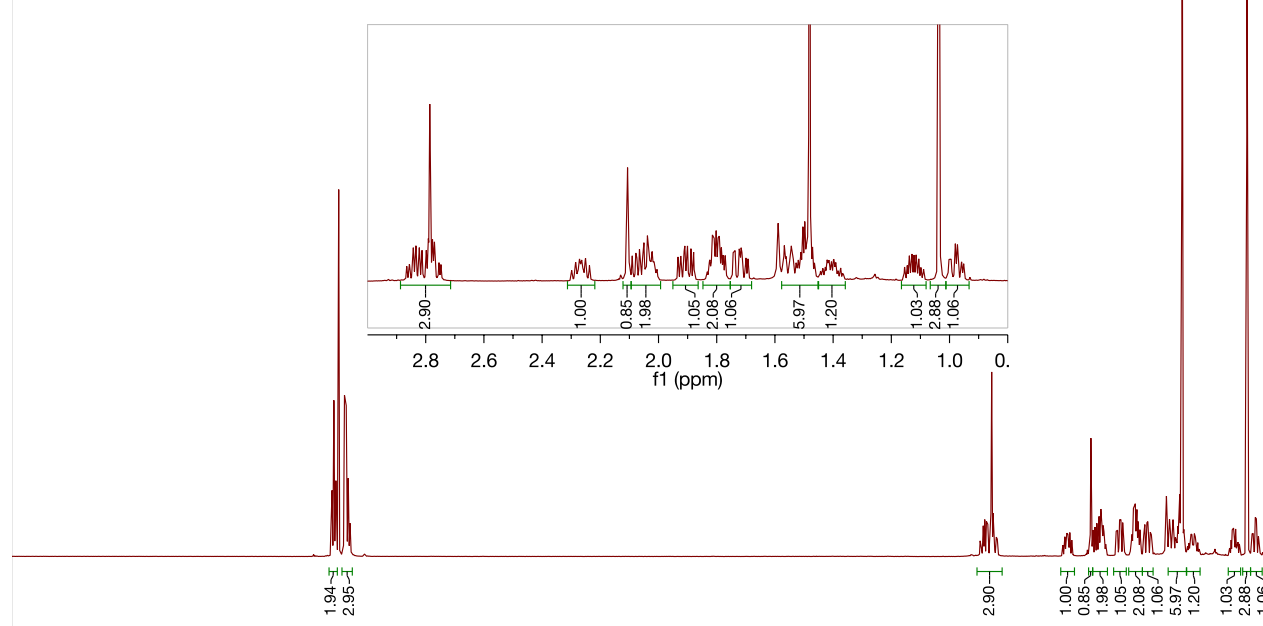

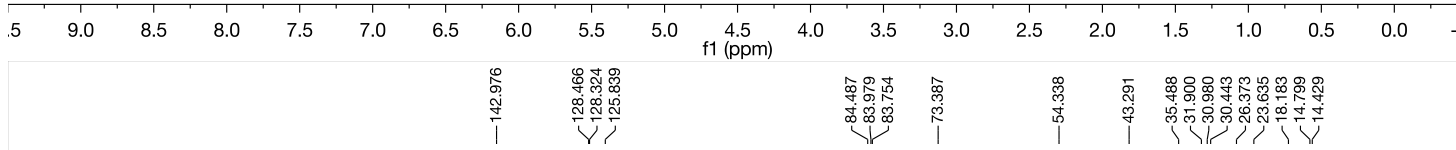
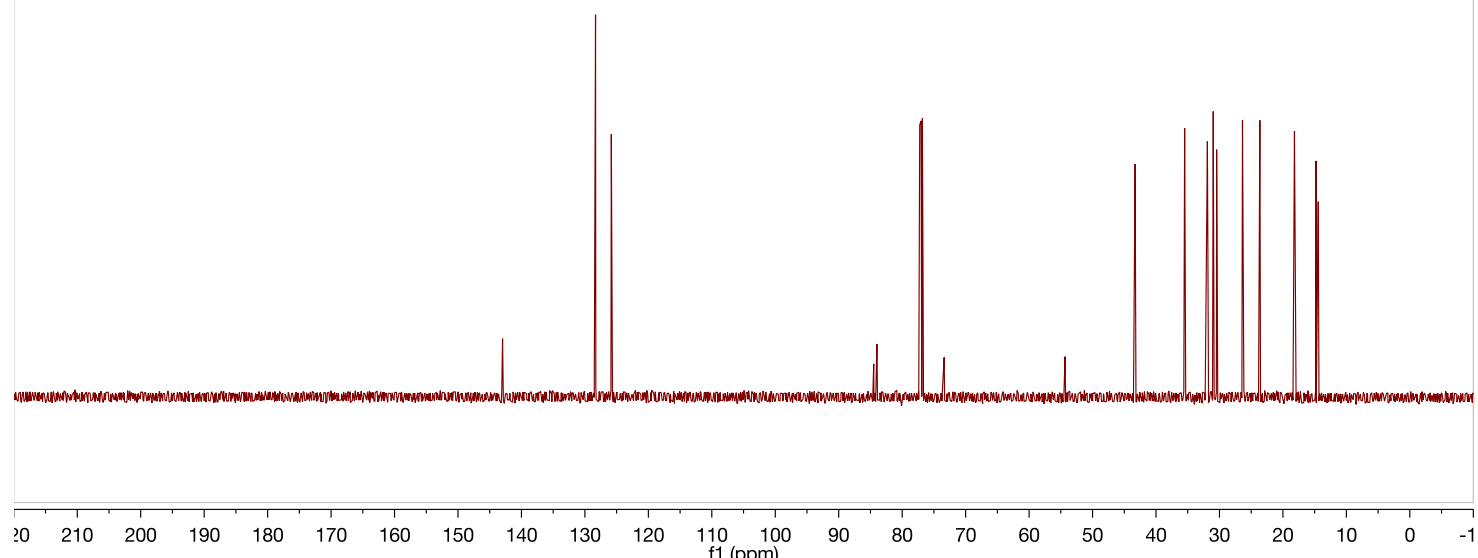

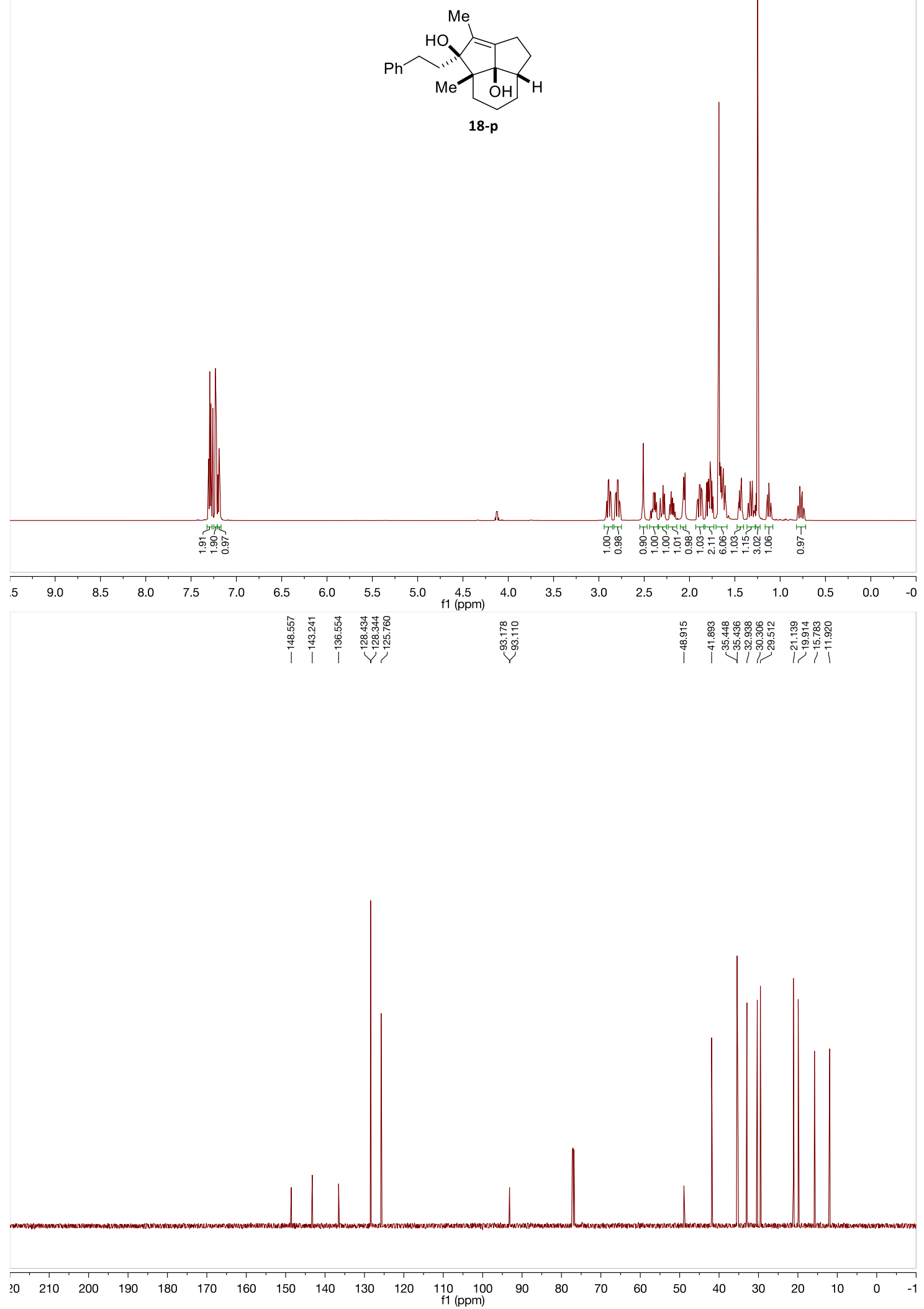


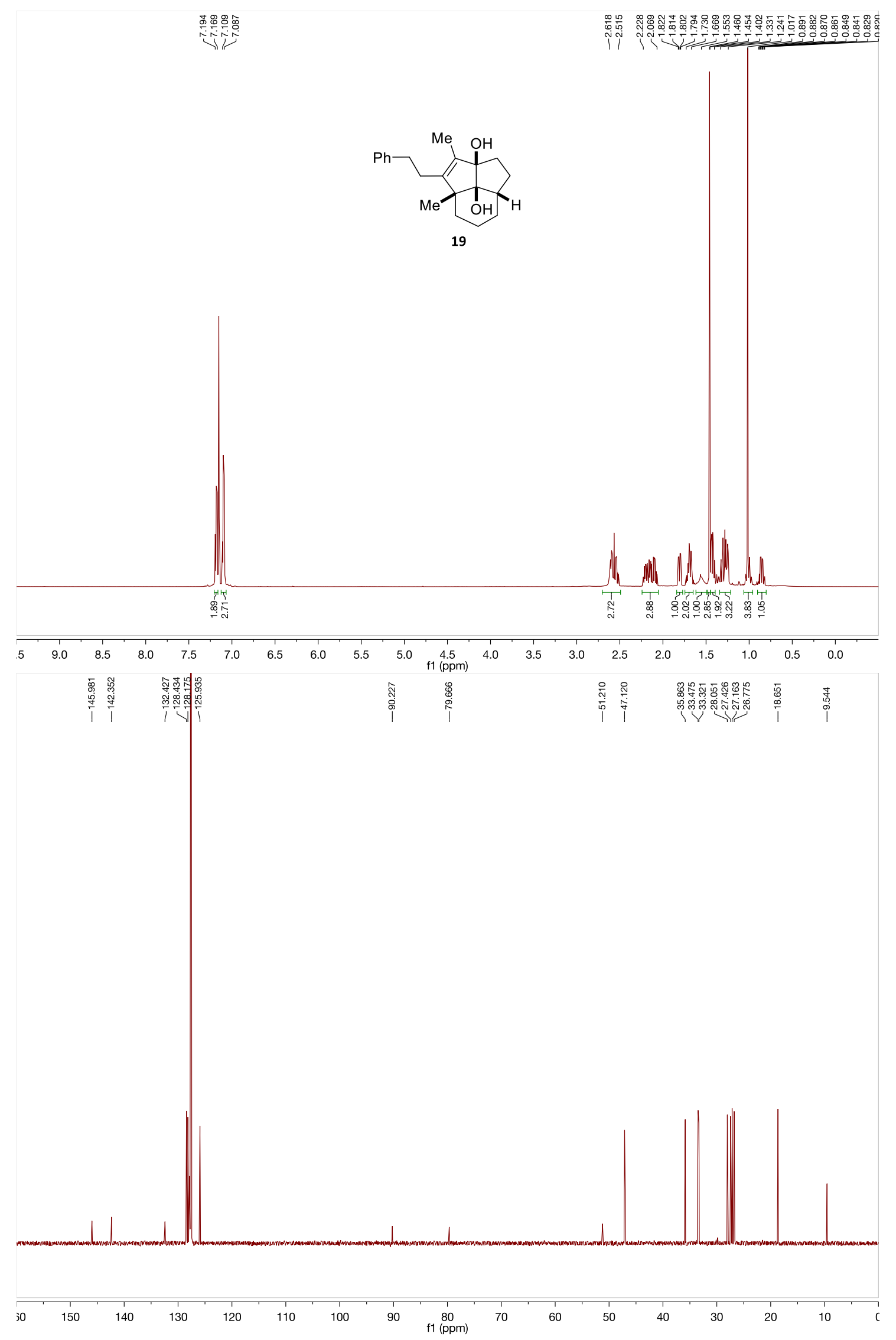



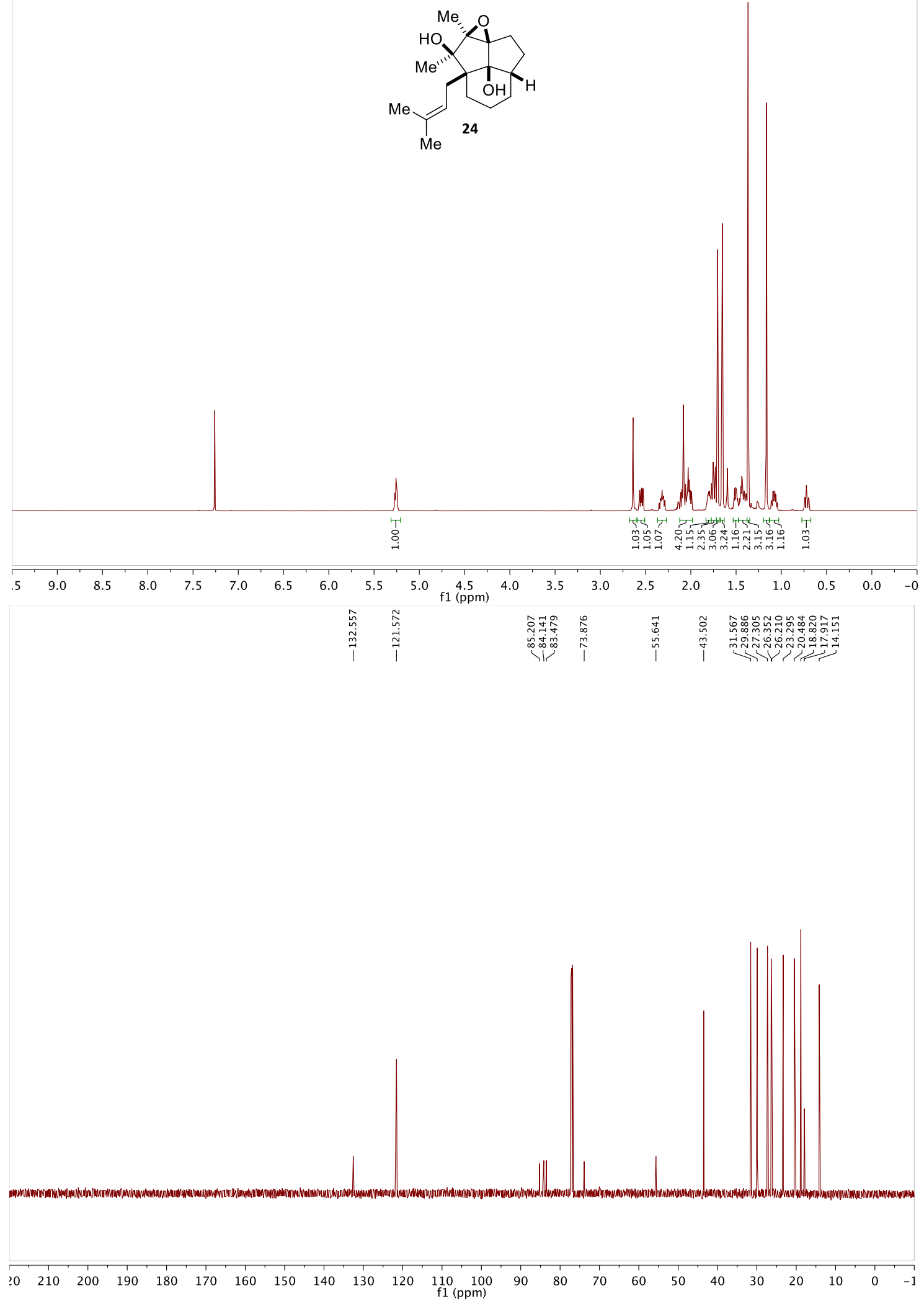

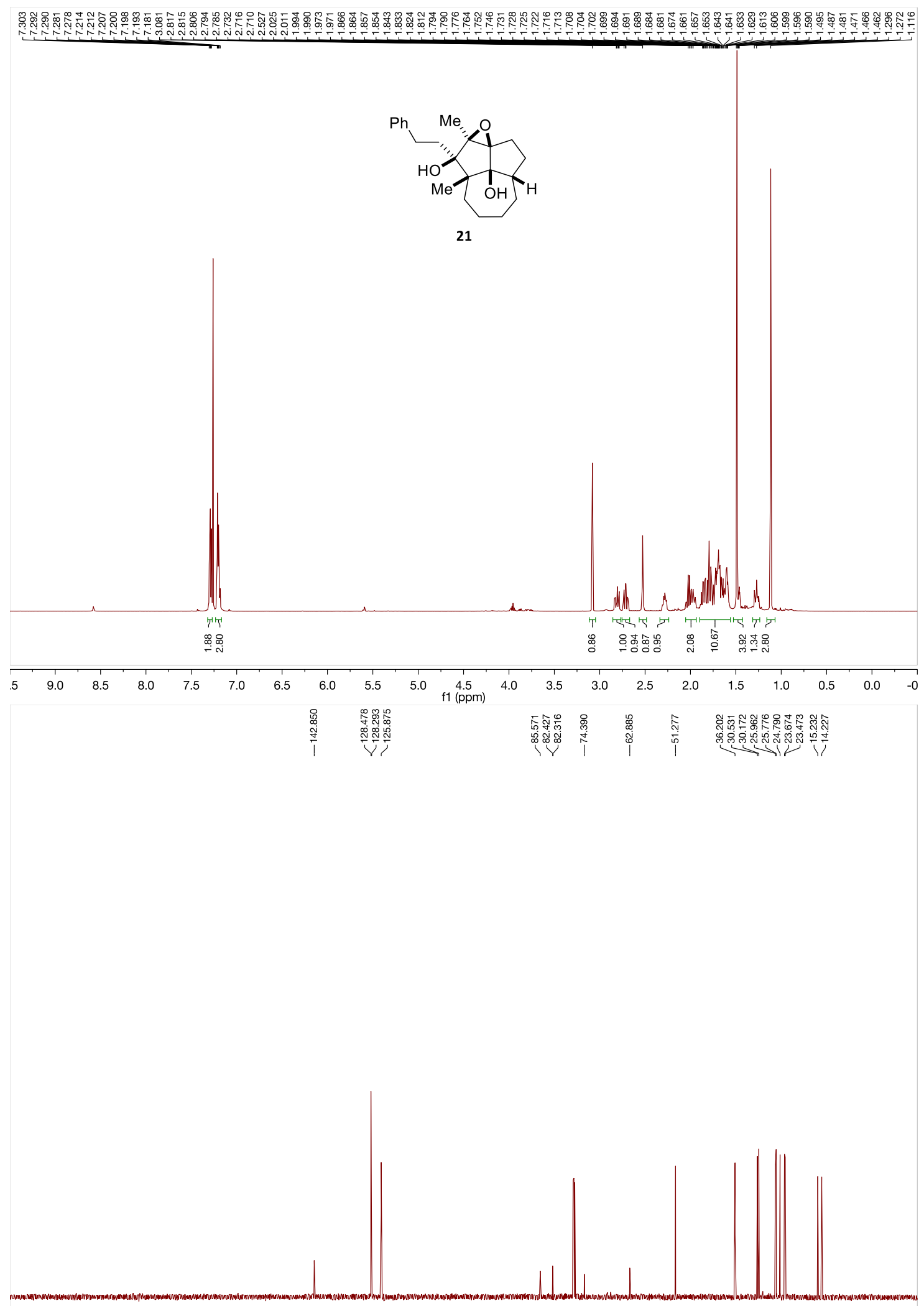

\begin{tabular}{llllllllllllllllllllllllllll}
\hline$\geq 0$ & 210 & 200 & 190 & 180 & 170 & 160 & 150 & 140 & 130 & 120 & $\underset{110}{110} 100$ & 90 & 80 & 70 & 60 & 50 & 40 & 30 & 20 & 10 & 0 & -1
\end{tabular} 

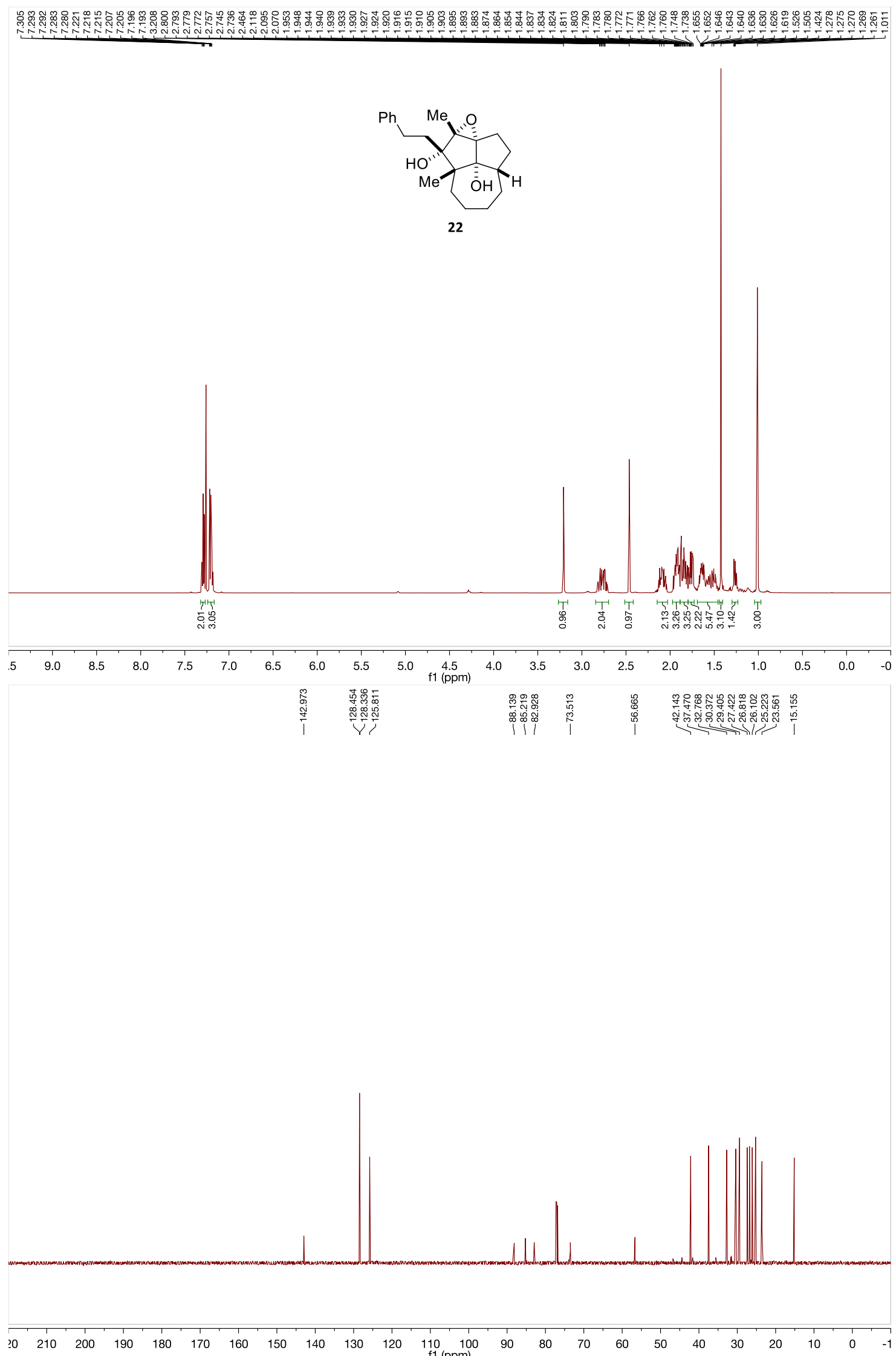